\title{
Synopsis: Special Issue on "Disruption of signaling homeostasis induced crosstalk in the carcinogenesis paradigm Epistemology of the origin of cancer"
}

\author{
Björn L.D.M. Brücher ${ }^{1,2,3,}$, and Ijaz S. Jamall ${ }^{1,2,4}$ \\ ${ }^{1}$ Theodor-Billroth-Akademie ${ }^{\circledR}$, Germany, USA \\ ${ }^{2}$ INCORE, International Consortium of Research Excellence of the Theodor-Billroth-Academy ${ }^{\circledR}$, Germany, USA \\ ${ }^{3}$ Department of Surgery, Carl-Thiem-Klinikum, Cottbus, Germany \\ ${ }^{4}$ Risk-Based Decisions Inc., Sacramento, CA, USA
}

Received 27 March 2018, Accepted 10 September 2019

\begin{abstract}
It is increasingly evident that carcinogenesis, in the vast majority of cancers, cannot be explained simply through an accumulation of somatic mutations, or epigenetics, the stem cell theory, or the Warburg effect. Here, decades of thinking based on incorrect assumptions has resulted in an incorrect hypothesis on the origin of cancer. Many papers studying DNA, genetics, RNA, miRNA, proteomics, and epigenetics have increased our understanding of biology. Our paradigm, though more complex, is more reliable and plausible. It states that cancer originates from a disruption of homeostasis. This essential biological phenomenon, homeostasis, maintains the interrelationships of various signaling pathways and induced crosstalk which modify cellular functions together with the interactions of surrounding cells and structures such that the equilibrium lies towards the optimal health of the organism. This Special Issue "Disruption of signaling homeostasis induced crosstalk in the carcinogenesis paradigm Epistemology of the origin of cancer" provides compelling evidence that carcinogenesis is explained by a six-step sequence of events for the vast majority of cancers. These six steps include, (1) a pathogenic stimulus followed by (2) chronic inflammation, from which develops (3) fibrosis with associated remodeling in the cellular microenvironment. From these changes a (4) pre-cancerous niche develops which triggers the deployment of (5) a chronic stress escape strategy, and when this fails to resolve, and (6) the transition of a normal cell to a cancer cell occurs. This paradigm provides opportunities to move away from a symptom-oriented understanding of cancer and is much closer to a cause-based understanding, which opens the door for early preventative strategies to mitigate cancer as a disease, and to interdict metastases. This is underpinned by the fact that an independent recently published proof of this paradigm showed how a stimulus trigger the proposed multi-sequence cascade of events as abrupt involution-induced chronic inflammation, followed by fibrosis with remodeling, which describes the pre-cancerous niche followed by hyperplasia, metaplasia, and cancer.
\end{abstract}

Keywords: Akt, Aneuploidy, AP-2, bcl-2, BRCA, Cancer, Carcinogenesis, CD44, Cell transition, CHK2, Chronic inflammation, Crosstalk, Disruption, DNA, ECM, EGFR, Eicosanoid, Epidemiology, Epigenetics, FADS2, Fibrosis, Genetics, Genomics, GLUT-4, HBV, HCC, HCV, HETE, Homeostasis, IKK, JNK, Lipid, LOX, LOXL2, LOXL3, LTA4, LTB4, LTD4, LTE4, Lysyl oxidase, LXA4, LXB4, MaR1, MaR2, Metabolism, MicroRNA, MMP, mRNA, Microbiome, Morbid obesity, Mutation, NPD1, p16, p53, p120, Pathogenesis, PAX, PCN, PGG2, PGH2, PI3K, PPAR, Precancerous niche, Proteomics, PUFA, Radiation, Reproducibility, RvD1, RvD2, RvD3, RvD4, RvD5, RvD6, Signaling, SMT, Somatic mutation theory, SOX-2, SPM, STAT3, Stem cell, Targeting therapy, Technology, TGF, Warburg

\section{Introduction}

Cancer mortalities (e.g., breast cancer in Europe and the USA) have declined largely due to the standardization of cancer diagnosis and therapy algorithms, effective

*Corresponding author: b-bruecher@gmx.de surveillance programs, and more efficacious adjuvant therapies [1]. However, we still cannot identify the root cause (s) of cancer for some $80 \%$ of sporadic cancers as required to shift away from the current symptomatic therapies to more effective cause-based approaches.

The health-care market is well funded but the majority of these monies are spent on symptom-orientated cancer 
research. The global cancer (research and treatment) spending in 2015 was determined to be about $\$ 100$ billion [2] while the US government was spending about $\$ 6$ billion in 2018 on cancer research alone [3]. By comparison, European cancer research funding in 2012-2013 amounted $\sim € 7.6$ billion [4].

A primary suggestion to change focus in cancer research to a cause- rather than a symptom-based strategy was published between 2014 and 2016 [5-9].

\section{Mutations, radiation, epigenetics, stem cells and Warburg theory}

\section{Mutations}

Mutations that are seen in liver tissues, but not in cancer, were associated with hepatocyte regeneration independent of carcinogenesis [10]. This reveals that there is a difference between correct observations, such as mutations, and how their phenotypic diagnostic and therapeutic relevance are evaluated. Importantly, to not mistake an association as causal to cancer as has been the case for the past seven decades. In a minority of cancers, mutations do appear to be indispensable to cancer, but for example, even in the majority of BRCA mutations these appear to be biologically neutral [11]. Therefore, it becomes clearer that "mutations - regardless of cause - may not be enough, even if necessary, to cause many cancers" ([12] reviewed in [13]).

This example, among countless others, illustrates why the value of the somatic mutation theory (SMT) as being the cause for the majority of cancers is increasingly being challenged [5, 6, 9, 14-34]. It does not help if such a "holy grail" as the SMT is explained by stochastic models [35-37]. It was noted that one cannot calculate either the number of key mutations nor the susceptibility to cancer in the general population using the statistical models described [38].

It has been suggested that $20 \%$ of "healthy" adults may carry disease-related mutations and that such mutations could be identified by whole exome sequencing (WES) [39]. However, it is noteworthy that only $17 \%$ of incidental or secondary mutations identified by WES $(n=70)$ revealed that only $7.1 \%$ of the variants detected could be classified as pathogenic. Thus, there is a difference between measured observations versus a disease phenotype or a mutation that is biologically neutral [11].

The presence of somatic mutations in cancer has been extensively reviewed [9]. Investigating the expression of proteins involved in DNA repair and/or cell-cycle regulation, such as tumor protein p53 (p53), phosphorylated p53 (phosphorylated at Ser15), epidermal growth factor receptor (EGFR), ATM serine/threonine protein kinase (ATM) (phosphorylated at Ser1981) and checkpoint kinase 2 (CHK2) (phosphorylated at Thr68) showed no predictive value in esophageal squamous cell carcinoma (ESCC) [40].

It is important to note that ATM protein kinase is recruited and activated by double strand breaks in DNA [41]. Therefore, it seems to serve as a more likely explanation for the lack of predictability of disease progression or survival from the use of biomarkers involved in DNA repair and/or cell-cycle regulation. Furthermore, extensive investigations of more common biomarkers, such as carcinoembryonic antigen (CEA) and CA199 for colon cancer show a low specificity and/or sensitivity [42] and suggests why the use of spectrometry might be of greater help in this regard [43].

The hysteron proteron syllogism "reverses both temporal and logical order and this syllogism occurs in carcinogenesis and SMT: the first (somatic mutation) occurs only after the second (onset of cancer) and, therefore, observed somatic mutations in most cancers appear well after the early cues of carcinogenesis are in place" [9]. Mutations do occur in cancerous tissue but the observed mutations and/or epigenetic and/or genetic changes in advanced cancer tissues have been consistently misinterpreted to suggest that mutations are causative for the majority of cancers. Where are the time series data that show a few mutations, then more mutations, until we see cancer develop? We consider that "somatic mutations are epiphenomena or later events occurring after carcinogenesis is already underway' [9]. The fact that a one-inch sample of cancerous liver tissue contains more than 100 million mutations [44], that identical mutations can result in different phenotypes [45], and analyses of physiologically healthy cells in the human esophagus reveal high levels of genetic alterations without cancer [46] makes it unlikely that such somatic mutations could be the cause for the vast majority of cancers [9].

It should be mentioned that even the mutation paradigm in Alzheimer's disease (AD) was recently questioned [47] and a paradigm shift away from mutations as causal to $\mathrm{AD}$ was proposed [48]. It is plausible that just by random chance alone mutation-induced $\mathrm{AD}$ is around $5 \%[49]$ as it is for cancer $[5,9]$.

With regard to somatic mutations and cancers, scientists should not persist in trying to fit an opinion or belief against reliable evidence to the contrary. We need to recognize, (1) "there are larger amounts of cell-free DNA in patients with late stage disease and metastasis", (2) the origin of the deoxyribonucleic acid (DNA) detected in fluids from cancer patients is uncertain and, so far, (3) there "is no evidence whether this DNA originates from dying "normal" cells or from cancer cells or from both" [5].

\section{Radiation}

Radiation is "the" stereotypical example in support of the primacy of mutations as being causative in cancer but a closer examination suggests that even for radiationinduced cancers a more nuanced view might be helpful. For example, the DNA damage caused by the A-bombs in Nagasaki and Hiroshima were different [9]. A low linear energy transfer (low-LET) radiation, which primarily causes single-strand DNA damage, was used in Nagasaki. Single-strand DNA damage can be repaired by DNA repair enzymes using the intact strand as a template and this explains why the dose-response curve for leukemia in Nagasaki A-bomb survivors was S-shaped, a dose-response curve which also applies for most non-carcinogenic chemicals and for pharmaceuticals ([50] reviewed in [9]). In contrast, the 
ionizing radiation from the A-bomb dropped on Hiroshima was of high linear energy transfer (high-LET) type causing mostly double-strand breaks in DNA and resulting in a more linear dose-response curve. This is because in the Hiroshima survivors, the DNA repair enzymes had no template to use to repair the damaged double strand DNA ([51] reviewed in [9]). These data explain why different leukemia incidence rates were observed with different dose-response curves after the two different A-bombs in Hiroshima and Nagasaki. Children with the autosomal recessive condition, Xeroderma pigmentosum (XP), have defective DNA repair enzymes [52,53] and illustrate why "only agents that cause double-strand DNA breakage become clinically relevant" [9].

\section{Epigenetics}

Epigenetic changes can result in hypermethylation which can silence tumor suppressor genes during carcinogenesis $[8,54,55]$ as shown in gastric cancer $[56,57]$ and in Helicobacter-driven gastric MALT lymphomas [58].

A step-wise loss of multiple protective barriers against $\mathrm{CpG}$ island hypermethylation was touted as being crucial to carcinogenesis since unique epigenetic changes were observed to occur at different steps in the progression of cancers [8]. Various viruses and bacteria induce $\mathrm{CpG}$ island methylation [57-63]. Both hypermethylation and hypomethylation "are independent processes and appear to play different roles in colorectal tumor progression" [64].

Chronic inflammation induces promoter $\mathrm{CpG}$ island methylation in cancer [62, 63, 65-67]. This is significant in that our old "belief" that epigenetic alterations occur only mitotically and meiotically heritable changes is no longer correct.

Clinicians are challenged by rare small bowel adenocarcinomas (SB-AC) due to their rareness and non-specific long-standing symptoms which may explain why SB-AC present in locally advanced tumor categories [68-70]. Investigating the prevalence of hypermethylation rates in a panel of mismatch repair gene human mutL homolog 1 , colon cancer, nonpolyposis type 2 ( $h M L H 1)$, hyperplastic polyposis 1 (HPP1), alternate reading frame tumor suppressor protein $\left(p 14 A R F, p 14^{A R F}\right)$, cyclin-dependent kinase inhibitor $2 \mathrm{~A}$, multiple tumor suppressor $1\left(p 16^{I N K 4 A}, p 16\right)$, and adenomatous polyposis coli $(A P C)$ were considered to have evolved during carcinogenesis in SB-AC with no differences in anatomical location but higher rates of HPP1 hypermethylation in advanced tumor categories versus early tumor categories (pT1/2 categories) were observed [71]. Interestingly, male patients showed a three-fold higher $A P C$ hypermethylation than females. Comparing the results against gastric adenocarcinomas revealed higher rates of hypermethylation in HPP1 and $p 16^{I N K 4 A}$ in SB-AC without differences in $h M L H 1$ and $p 14^{A R F}$ suggested epigenetic differences between these tumor entities.

Subsequently, it was shown that the majority of sporadic cancers, usually diagnosed in advanced tumor categories, show more varied epigenetic alterations [72]. It remains possible, however, that methylated free-circulating DNA, such as HPP1 DNA, might serve as an early marker in colorectal cancer (CRC) patients who are transitioning to metastasis [73].

It has been pointed out that "we have epigenetic changes as a subset of gene regulatory changes (i.e., self-perpetuating changes) and in the older Waddington sense we could refer to all developmental gene regulation (including signaling) as "epigenetic." But in neither case is it correct to refer to nucleosome modifiers as epigenetic" and "the important point is to attend to how things actually work" [74]. Furthermore, epigenetic changes are "important in the recruitment and regulation of the natural cellular engineering processes that are involved in DNA repair and the control of transposition and recombination" as "natural selection and natural genetic engineering overrule gene flow, evolving divergent ecological adaptive complexes" ([75] reviewed in [76]).

Paired-box genes (PAX) represent a family of transcription factors which encode proteins with DNA-binding motif and a paired domain (PD). They are classified into four major groups: group 1 (PAX1, PAX9), group 2 (PAX2, PAX5, PAX8), group 3 (PAX3, PAX7), and group 4 (PAX4, PAX6) [77-79]. After the discovery of homeobox gene by Walter Gehring ([80-82] reviewed in [83]), he discovered that PAX6 (aniridia type II protein, AN2, paired box 6) is responsible for eye development in fruit flies [84, 85]. Since then it has been shown that PAX6 has three isoforms and that it is important for embryogenesis of various tissues [86-89]. Subsequently, the potential association between PAX6 and cancer was investigated.

PAX6 is involved in normal corneal wound healing with its upregulation [90]. Otherwise, PAX6 overexpression is associated with poorer survival in invasive ductal breast cancer [91]. Increase of hypermethylation of tumor suppressing PAX6 was found to be associated with cancers of the prostate [92, 93], breast [94-97], stomach [98, 99], brain [100], and the colorectum [101]. Hepatitis C virus (HCV) positive hepatocellular carcinoma (HCC) tissue frequently $(>60 \%)$ showed methylated PAX6, which rarely occurred in hepatitis B virus (HBV) positive HCC tissues [102]. Interestingly, the methylation rates of various genes are higher in HCV-HCC compared to normal tissue or HBVHCC [103].

However, hypermethylation status should be evaluated with caution as it is necessary to know if this is found in normal tissue and we know that hypermethylation in cancer does not always involve promoter-associated CpGislands. Moreover, methylation increases with age $[8,104$, 105]. With regard to PAX6, silencing by methylation was found to be increased in tumor versus normal tissue and associated with poor survival in non-small lung cancer [106]. PAX6 overexpression increases cell migration in breast cancer, which seems to be affected by the methylation status, and increases matrix metalloproteinase 2 (MMP-2, gelatinase A) and matrix metalloproteinase 9 (MMP-9, gelatinase B), both of which are important for carcinogenesis and metastasis while the promoter methylation of PAX6 has a negative impact on cell spread and proteases expression [97].

Physical interactions between PAX6, transforming growth factor beta 1 (TGF- $\beta 1$ ), and secreted protein acidic 
and rich in cysteine (SPARC) have been demonstrated by co-immunoprecipitation (Co-IP) assay in retinal layers but the TGF- $\beta$ regulation here seems to be PAX6-dependent in a tissue-specific manner [107]. However, data in terms of the PAX6 association with various biomarkers and cancer are missing.

\section{Stem cells}

The transition from adult mesenchymal stem cells depends on homeostasis and its disruption of the extracellular matrix $(\mathrm{ECM})$ with various transcription factors and cytokines ([108] reviewed in [9]). Even epithelial mesenchymal transition (EMT) itself can induce non-cancer stem cells to become stem cells $([109,110]$ reviewed in [111]). "If a cancer arises in a single stem cell, then the spontaneous mutation rate would account for less than one mutation per tumor" [2]. The suggestion that "mutator phenotype" theory would explain how a large number of mutations could possibly be generated [112] was proven to be incorrect as reviewed above [11].

\section{Warburg effect and cancer}

As reviewed [113], Warburg and Cori observed that lactic acid is produced by cancer cells from the activation of anaerobic glycolysis [114-118]. To better understand how this led to a postulation that the majority of cancers would develop from anaerobic glycolysis we need to take a step back.

The metabolic physiology of oxidation goes back some 250 years [119-125]. It was the German chemist and physiologist, Max Rubner (1854-1932), who showed that food ingestion increases oxidation and is dependent on specific foods with higher rates for meat compared to fat or sugar and it was Rubner who postulated that metabolism is directionally proportional to the surface area of the body, known as the Surface Law [126-134].

Later it was shown, that "increased acidity leads to decreased oxidation" [135]. Rabbits exposed to high carbon dioxide and normal oxygen in the atmosphere showed stimulation of the cardiorespiratory systems without bone marrow hyperplasia but with a hydropic parenchymal degeneration in some organs especially in the liver, with a more peripheral location. Low oxygen content stimulated the cardiorespiratory system together with a marked hyperplasia of red bone marrow, spleen and the thyroid together with a low rate of more central hyaline cell degeneration of parenchymatous tissue of organs and necrosis. This was concordant to prior findings [136].

Furthermore, it was assumed that vegetarians would have lower incidences of chronic diseases, such as cancer, but it was proven, that vegetarians and non-vegetarians have similar all-cause mortality including for cancer [137-139] although this seems to be dependent on the type of cancer [140, 141].

Warburg and Cori's observations were significant to our understanding of biology. However, glycolysis is "known to be common among developing or regenerating tissues, whether normal or neoplastic, and the tricarboxylic acid (TCA) cycle to be basically intact in neoplastic tissues" ([142] reviewed in [113]).

The above discussion suggests that the majority of cancers are unlikely to have originated from mutations, radiation, epigenetics, stem cells, or the Warburg effect.

\section{Independent proof of cancer paradigm "Epistemology of the origin of cancer" - Complexity in animal model}

A recent paper demonstrated how a pathogenic stimulus induces the multi-sequence cascade of events we proposed that includes abrupt involution-induced chronic inflammation, followed by fibrosis with remodeling, which describes the pre-cancerous niche (PCN) followed by hyperplasia, metaplasia, and cancer [143]. That this study was conducted without prior knowledge of our paradigm and without citing our previously published papers adds support for our paradigm.

\section{Synopsis of evidence}

The explanation as to how cancer cells originate is complex. It involves ubiquitous proteins [144] developing from an ongoing pathogenic stimulus with unresolved chronic inflammation [145]. This, in turn, results in fibrosis with its remodeling and generation of the PCN [146]. The PCN promotes ongoing chronic cell matrix stress resulting in the normal cell-to-cancer cell transition [111]. This sequence is influenced by the microbiome [147], its modulation by Metformin [148] as well as the metabolism of eicosanoids [149] and nuclear factor kappa-light-chain-enhancer of activated B cells (NF- $\kappa \mathrm{B})$ signaling [150] all of which have been described in considerable detail in this Special Issue.

However, we acknowledge that the complexity of various sequences and specific conditions that must be considered [113].

\section{Chronic inflammation evoked by pathogenic stimulus}

The available information in regard to chronic inflammation evoked by pathogenic stimulus during carcinogenesis was extensively discussed [145] and further supported by more recent data. For example, some $25 \%$ of patients asymptomatic for benign prostatic hyperplasia (BPH) were positive for Trichomonas vaginalis ( $T$. vaginalis) and an even higher percentage exhibited seropositivity against antibodies [151]. Thus, the findings of T. vaginalis in association with normal and prostatic tissues from chronic inflammatory prostatitis, BPH, and prostate cancer [152] may be more important than previously believed as one source of an ongoing pathogenic stimulus ( $T$. vaginalis exposure) induces chronic inflammation within the prostate in an experimental model [153] with increases of interleukin 1 beta (IL-1 $\beta$ ) and chemokine (C-C motif) ligand 2 (CCL2) in a time-dependent manner leading to the transition from a normal cell to a cancer cell [154]. Chronic T. vaginalis infection creates the microenvironment conducive to cancer 
development [155, 156]. Likewise, it has been shown that consistent chronic lung inflammation results in metaplasia and cancer [157].

This is concordant with findings on how a pathogenic stimulus in epidermal cells induces inflammation and, when unresolved, can lead to carcinogenesis [158] or to precancerous hyperplasia and endometrial cancer [159]. Even breast cancer shows such a sequence as when pathogenic stimuli, such as (HPV) type 6/11 and 16/18 infections, are followed by fibrosis with its remodeling increases the risk of such cancers [160].

\section{Cell communication, mechanotransduction and eicosanoid metabolism}

The mechanotransduction recorded in cell-cell and stroma communication has been extensively reviewed together with the undervalued ubiquitous proteins and eicosanoid metabolism $[6,144,149]$. This alone once again supports the notion that there is no such thing as "the" and/or "one" Achilles' Heel in cancer or carcinogenesis.

In lung cancer, the ECM protein, fibronectin, is increased and stimulated by the lipoxygenase metabolite of arachidonic acid, 12(steoreoisomer)-hydroxyeicosatetraenoic acid (12(S)-HETE), but not by 12("R" stereoisomer)-hydroxyeicosatetraenoic acid (12(R)-HETE), 5-hydroxyeicosatetraenoic acid (5-HETE) or 15-hydroxyeicosatetraenoic acid (15-HETE, $\quad$ (5Z,8Z,11Z,13E)-15-hydroxyicosa-5,8,11,13tetraenoic acid) [161]. Fibronectin is increased by TGF- $\beta 1$ [162] in more aggressive cancers in the stroma but not in the tumor cells themselves [163]. Otherwise, fibronectin was reported in the 80 s as not being a useful marker as it was not increased in cancer cells [164]. It should be noted that the cancer cells were the focus of studies in the 80 s and beginning of the 90s, not the stroma, which explains why the role of fibronectin was previously undervalued.

Fibronectin protects lung cancer cells against chemotherapy induced apoptosis [165]. Culturing human ovarian cancer cells (OVCAR-3, A2780/CP70) with fibronectin increases signaling regulation of the focal adhesion kinase (FAK) pathway (phosphorylated phosphoinositide 3-kinase $(\mathrm{pPI} 3 \mathrm{~K}) /$ phosphorylated phosphorylated protein kinase B (pAKT) with the ability to migrate and invade tissue which can be inhibited by FAK siRNA [166]: fibronectin plays a role in metastasis as well.

Cluster of differentiation 44 (CD44) is increased by pathogenic stimulus in carcinogenesis and also increased by chronic TGF- $\beta 1$ [111]. Targeting glioblastoma cells expressing CD44 with liposomes encapsulating doxorubicin was reported to suppress tumor growth [167]. CD44 induces integrin-mediated signaling for increasing adhesion to facilitate extravasation and increases adhesion to fibronectin which enables cancer cells to adhere more efficiently [168]. Therefore, it is currently thought that targeting fibronectin may be helpful in cancer therapy and also in cancer imaging [169].

Focal adhesion kinase (FAK) and the protein, paxillin, promote migration and adhesion to fibronectin [170]. Paxillin is increased in various lesions, such as hyperplasia, dysplasia, metaplasia, and cancers [171] and connects integrin to FAK [172].

PAX6 is under investigation in embryogenesis [86-89, $173,174]$. However, transcription factors can be differently expressed viz., neuroblasts in the human subventricular zone showed increased Sox-2 expression in the nuclear region, whereas PAX6 immunoreactivity was detectable in both the nucleus and the cytoplasm [175]. The cell adhesion integral membrane molecule, L1, consists of six Ig domains together with five fibronectin types, three repeats, and a cytoplasmic domain [176]. Here a binding site for homeodomain and PAX proteins is necessary for L1 adhesion [177].

More detailed mechanistic information was recently provided for PAX6: the transcription factor PAX6 binds on zinc finger E-box-binding homeobox 2 (ZEB2) and upregulates PI3K/Akt signaling with E-Cadherin decrease downregulating apoptosis in lung cancer [178]. Detailed information about lysyl oxidase (LOX), or its isoforms, with PAX6 signaling are warranted. PAX6 was shown to increase MMP-2 and MMP-9 [97], both of which are important for the degradation and destruction of the ECM [9]. Furthermore, co-expression of PAX6 and C-X-C chemokine receptor 4 (CXCR4) was shown in pancreatic cancer [179], although here the mechanistic interactions are presently not known.

\section{Fibrosis with its remodeling and generation of the precancerous niche (PCN)}

Inducing the precancerous niche (PCN) in its entirety reveals how carcinogenesis can occur [146]. In this context, the influence by the microbiome and obesity, and the role of Metformin are discussed [147] along with the different influences by various NF- $\kappa \mathrm{B}$ signaling pathways [150] which all have been reviewed extensively. New reports suggest that Metformin can reverse the mesenchymal phenotype of primary breast cancer cells through signal transducer and activator of transcription 3 (STAT3)/ NF- $\kappa$ B pathways [180].

As reported [146], the copper-dependent amine oxidases of the LOX its isoforms and receptors, together with the study of cancer-resistant species such as the naked mole rat or Spalax are relevant. The LOX family consists of LOX, lysyl oxidase-like protein 1-4 (LOXL1, LOXL2, LOXL3, and LOXL4) and these are important for ECM stiffness, stabilization [181], as well as for its remodeling with altered signaling during carcinogenesis [146]. LOX have a pivotal role in TGF- $\beta 1$-induced carcinogenesis as well as in cutaneous fibrosis through impaired ECM homeostasis in skin-like tissues [182].

LOXL3 is key regulator of integrin signaling and known to oxidize fibronectin to augment the signal transduction adaptor protein, phosphorylated Paxillin, which appears to be an essential step for matrix formation [183].

The extracellular LOXL3 is expressed in the cytoplasm in melanoma and kidney cells ([184, 185] reviewed in [181]) but predominantly translocated to the nucleus as was observed in gastric cancer ([186] reviewed in [181]). 
It may be relevant that LOXL3 in humans presents "potential transcription factor binding sites for STAT3, signal transducer and activator of transcription 6 (STAT6), serum response factor (SRF) muscle integrin binding protein $(M I B P) /$ regulatory factor X1 (RFX1), specificity protein 1 (SP1), nuclear factor 1 (NF1), neuron-restrictive silencer factor (NRSF, RE1-silencing transcription factor, $R E S T), c A M P$ response element (CRE)-binding protein 1 (CREB), PAX-6 paired domain, interferon regulatory factor (IRF)-related protein, GATA binding factor 1, NF- $\kappa B$, GAGA box, proto-oncogene c-Rel (c-Rel) sites, and activating protein 2 (AP-2)" ([187] reviewed in [181]).

\section{Chronic cell matrix stress resulting in the normal-to-cancer cell transition}

"In biology, the transition of one cell type to another and the transition from one cell function to another is incompletely understood mechanistically, but within the context of embryogenesis and morphogenesis is acknowledged as a physiologically routine event" [111]. Catenin delta-1 (p120) regulates lung fibroblast differentiation induced by TGF- $\beta 1$ [188]. Chronic cell matrix stress increases p120 within the cytoplasm, and destabilizes epithelial cadherin 1 (E-Cadherin, CAM 120/80), which explains why apoptosis is inhibited under these conditions [189, 190]. A central role for p120 in chronic cell stress response was also shown in drosophila [191]. However, p120 and its isoforms 1 and 3 (p120-1 and p120-3) are differently expressed in epithelial tissues [192].

During carcinogenesis, the disruption of p120 homeostasis is relevant as p120 isoform 1 promotes transition cell invasiveness while isoform 3 inhibits both [193] which makes it more complex as the effects of p120 depend on its isoforms. The obstacle of cell transition increases that complexity as intermediate cell states have been identified [194]. Although there is hope that influencing cell transition could be used in treating disease [195], much work needs to be done to first fill in the gaps in our knowledge.

We acknowledge the complexity illustrated by lipid metabolism as discussed below.

\section{Disruption of lipid metabolism}

The homeostasis of pro- and anti-inflammatory effects during carcinogenesis is disrupted in multiple ways, which reveal why the focus on any one signaling pathway will not suffice to interrupt carcinogenesis.

One important aspect lies in fatty acid metabolism which results in various intra- and extracellular mediators [149] with pro-inflammatory effects, such as prostaglandins, such as prostaglandin G2 (PGG2, (Z)-7-[(1S,4R,5R,6R)-5- [(E,3S)3-hydroperoxyoct-1-enyl]-2,3-dioxabicyclo[2.2.1]heptan6-yl]hept-5-enoic acid) and prostaglandin $\mathrm{H} 2$ (PGH2, (Z)-7-[(1S,4R,5R,6R)-5-[(E,3S)-3-hydroxyoct-1-enyl]2,3-dioxabicyclo[2.2.1]heptan-6-yl]hept-5-enoic acid, leukotrienes (LTs), such as leukotriene A4 (LTA4, 4[(2S,3S)-3-[(1E,3E, 5Z,8Z)-tetradeca-1,3,5,8-tetraenyl]oxiran2-yl]butanoic acid), leukotriene B4 (LTB4, (5S,6Z,8E,10E,
12R,14Z)-5,12-dihydroxyicosa-6,8,10,14-tetraenoic acid), leukotriene C4 (LTC4, (5S,6R,7E,9E, 11Z, 14Z)-6-[(2R)-2[[(4S)-4-amino-4-carboxybutanoyl]amino]3-(carboxymeth ylamino)-3-oxopropyl]sulfanyl-5-hydroxyicosa-7,9,11,14tetraenoic acid), leukotriene E4 (LTE4, (5S,6R,7E,9E, 11Z,14Z)-6-[(2R)-2-amino-2-carboxyethyl]sulfanyl-5-hydroxyicosa-7,9,11,14-tetraenoic acid), leukotriene D4 (LTD4, (5S,6R,7E,9E,11Z,14Z)-6-[(2R)-2-amino-3-(carboxymethylamino)-3-oxopropyl]sulfanyl-5-hydroxyicosa-7,9,11,14-tetraenoic acid) and anti-inflammatory specialized pro-resolving lipid mediators (SPMs), such as lipoxines (LXs), such as lipoxin A4 (LXA4，5S,6R,15S-trihydroxy-7E,9E, 11Z,13E-eicosatetraenoic acid), lipoxin B4 (LXB4, 5S, 14R,15S-trihydroxy6E,8Z,10E,12E-eicosatetraenoic acid), resolvins (RVs), such as resolvin D1 (RvD1, (4Z,7S,8R, 9E,11E,13Z,15E,17S, 19Z)-7,8,17-trihydroxydocosa-4,9,11, 13,15,19-hexaenoic acid), resolvin D2 (RvD2, $(4 \mathrm{Z}, 7 \mathrm{~S}, 8 \mathrm{E}, \quad 10 \mathrm{Z}, 12 \mathrm{E}, 14 \mathrm{E}$, 16R,17S,19Z)-7,16,17-trihydroxydocosa-4,8,10, 12,14,19-hexaenoic acid), resolvin D3 (RvD3, (4S,5E, 7E,9E,13Z, 15E,17R,19Z)-4,11,17-trihydroxydocosa-5,7,9,13, 15,19hexaenoic acid), resolvin $\mathrm{D} 4(\mathrm{RvD} 4,(4 \mathrm{~S}, 6 \mathrm{E}, 8 \mathrm{E}, 10 \mathrm{E}$, 13E,15Z,17S,19Z)-4,5,17-trihydroxydocosa-6,8,10,13,15, 19 hexaenoic acid), resolvin D5 (RvD5, (5Z,7S,8E,10Z,13Z, 15E,17S,19Z)-7,17-dihydroxydocosa-5,8,10,13,15,19-hexaenoic acid), and resolvin D6 (RvD6, (4S,5E,7Z, 10Z,13Z, 15E,17S,19Z)-4,17-dihydroxydocosa-5,7,10,13,15, 19-hexaenoic acid), such as neuroprotectin D1 (NPD1, protectin $\quad \mathrm{D} 1, \quad(4 \mathrm{Z}, 7 \mathrm{Z}, 10 \mathrm{R}, 11 \mathrm{E}, 13 \mathrm{E}, 15 \mathrm{Z}, 17 \mathrm{~S}, 19 \mathrm{Z})-10,17-$ dihydroxydocosa-4,7,11,13,15,19-hexaenoic acid), and maresins, such as maresin 1 (MaR1, (4Z,7R,8E,10E,12Z,14S, 16Z,19Z)-7,14- dihydroxydocosa-4,8,10,12,16,19-hexaenoic acid) and maresin 2 (MaR2, 13R,14S-diHDHA).

Noticeable within fatty acid (FA) metabolism is the homeostasis between synthesis in the cytoplasm and the endoplasmic reticulum in humans (and plastids in plants) while FA degradation takes place within the mitochondria, peroxisomes, and glyoxosomes [196-201].

Humans consume predominantly six common edible saturated FA, such as hexadecanoic acid (palmitic acid), (9Z)-hexadec-9-enoic acid (palmitoleic acid), octadecanoid acid (stearic acid, cetylacetic acid), cis-9-octadecenoic acid (oleic acid), linoleic acid (LA, cis, cis-9,12-octadecadienoic acid) and $\alpha$-linolenic acid (ALA, (9Z,12Z,15Z)-octadeca9,12,15-trienoic acid) [149, 202, 203].

Fatty acid precursors such as ALA are converted to the more pro-inflammatory $n-6$ polyunsaturated fatty acid (omega-6-, $\omega-6-P U F A s: ~ C 20 H 32 \mathrm{O} 2,20: 4(\omega-6)$ ), such as dihomo gamma-linolenic acid (DGLA), arachidonic acid $(A A)$, docosatetranoic acid, (7Z,10Z,13Z,16Z)-7,10,13, 16docosatetraenoic acid (DTA) and osbond acid, (All-Z)4,7,10,13,16-docosapentaenoic acid (BDPA), and through LA into the less inflammatory $n-3$ polyunsaturated fatty acids (omega-3-, $\omega-3-P U F A s$ ), such as eicosatetraenoic acid, all-cis-8,11,14,17-eicosatetraenoic acid (ETA), eicosapentaenoic acid, (5Z,8Z,11Z,14Z,17Z)-eicosa-5,8,11,14,17pentenoic acid $(E P A)$, docosapentaenoic acid, 7,10,13,16, 19-docosapentaenoic acid (DPA) and docosahexaenoic acid, (4Z,7Z,10Z,13Z, 16Z,19Z)-docosa-4,7,10,13,16,19-hexaenoic acid $(D H A)$. 
Key reaction in biosynthesis of PUFA is desaturation [203-205]. Enzymes transfer electrons from one molecule to another and desaturate the substrate by adding a double bond. FA with double bonds are essential and need to be ingested in food because specialized desaturases are missing. So-called $\Delta$-desaturases are classified in regard to the double bond position counting from the methyl end, e.g. delta-9, delta- 6 and delta-5 types $([206,207]$ reviewed in [208]).

In the following we will not focus on the bacterial desaturase (DesA), cyanobacterial DesA, which is important for cooling tolerance. Lipid membranes are temperaturedependent based on the grade of saturation [209] and specialized FA can generate an increased tolerance against cold temperatures in higher plants [210]. Instead we will focus on stearoyl-CoA desaturase-1 (SCD1) and fatty acid desaturase 2 (FADS2).

\section{Stearoyl-CoA desaturase-1 $(S C D 1)=\Delta-9$ desaturase (D9D)}

Stearoyl-CoA desaturase-1 (SCD1) [206, 211-214] is a $\Delta-9$ desaturase (D9D). SCD1 is essential for the de-novo triglyceride biosynthesis [215]. Mono-unsaturated fatty acids (MUFA), such as oleic acid and palmitoleic acid are substrates for various lipid syntheses, such as triglycerides (TGs), wax esters, cholesterol esters and phospholipids. In importance, next to various cell communication molecular pathways $[6,149]$ is the ratio of saturated to unsaturated FA in the phospholipids as this influences the stability and fluidity of membranes and thus influences signal transduction [216]. SCD1-expression influences the membrane phospholipid composition.

SCD1-deficiency is associated with reduced obesity and decreased liver steatosis independent of peroxisome proliferator-activated receptor-alpha (PPAR $\alpha)$ [217]. Deficiency of SCD1 also results in reduced arteriosclerosis [218], adiposity [217, 219], adipose tissue associated inflammation [220, 221] inhibits glycogen synthase kinase 3 (GSK3) phosphorylation, and decreases $\beta$-catenin translocation to the nucleus with consecutive decrease of cell proliferation and cell transition in breast cancer cells [222]. Therefore, SCD1 inhibitors hold the promise of being targets in anticancer therapy [223].

The mediator of increased hepatic FA oxidation in SCD1-deficiency is the phosphorylation and activation of AMP-activated protein kinase (AMPK) which act like a metabolic sensors [224]. Pharmacological SCD1 inhibition inactivates acetyl-CoA carboxylase via AMPK and impairs proliferation in lung cancer cells [225]. SCD1 is positively regulated by insulin [226] and vitamin A [227] and suppressed by triiodothyronine (T3) [228]. In obesity, leptin decreases SCD1-independent of insulin [229] and insulin activates SCD1 expression through PI3K and the mechanistic target of rapamycin (mTOR) as well as the downstream transcription factors nuclear factor $\mathrm{Y}(\mathrm{NF}-\mathrm{Y})$ and sterol regulatory element-binding protein 1 (SREBP-1) [230].

PI3K/mTOR signaling upregulates SCD1 [231-233]. Furthermore, EGFR binds and phosphorylates SCD1 and cancer cell growth stimulated by EGFR depends on SCD1 activity [234]. SCD1 controls cancer metabolism as well as proliferation and cell-survival through EGFR/ Akt/extracellular signal-regulated kinase (ERK) signaling [235]. SCD1 decreases apoptosis, increases proliferation, and metastasis-related EGFR/PI3K/Akt signaling plus up-regulation of epithelial to mesenchymal transition (EMT) phenotype in lung cancer, which could be restored by SCD1 inhibition. In this case, SCD1 inhibition is required for anti-EGFR therapy in lung cancer [236].

NF- $\kappa \mathrm{B}[150]$ upregulates SCD1 at the transcriptional level [237]. SCD1 inhibition also blocks NF- $\kappa$ B signaling and downregulates interleukin 6 (IL-6) but the exact signaling pathway remains to be elucidated. Furthermore, the degree of disruption of homeostasis is important as only moderate activation of inhibitor of nuclear factor kappa-B kinase 2 (IKK2, inhibitor of nuclear factor kappa-B kinase subunit beta, IKK- $\beta$ )-NF-kB in unstressed adult mouse liver cells seems to induce lipogenesis and to be cytoprotective without apparent inflammation and fibrosis [238]. This appears to be related to the strong activation of the antiinflammatory IKK1-RelB alternative NF-kB pathway. Knockdown of SCD1 by shRNA reduced the mRNA expression of aldehyde dehydrogenase 1 family member A1 (ALDH1A1), the homeobox protein Nanog, sex determining region Y (SRY)-box 2 (Sox2), and octamer-binding transcription factor 4 (Oct-4) [237].

Angiotensin II (ANGII) promotes the formation of multicellular spheroids (MCS) and peritoneal metastasis through EGFR transactivation and activation of its receptor, angiotensin II receptor type 1 (AGTR1, $\mathrm{AT}_{1}$-receptor), increases the lipid desaturation via SCD1 upregulation explaining why high AGTR1 levels are associated with poor outcomes in ovarian cancer [239].

Cancer cells usually have a much higher proliferation rate than normal cells and require a higher proportion of PUFA for their cell membranes as well as for the formation and stabilization of cell membranes ([240] reviewed in [241]). Fibroblasts [242] and SV40-triggered transformed fibroblasts upregulate SCD1 [243].

Increased SCD1 is associated with cancers and cell lines of the breast [244, 245], ovarian [246], hypopharynx [240], thyroid [247], esophagus [248], colon [248-250], liver [248, 251, 252], the lung [241, 253-255], kidney [256], and the prostate [257] as well as in melanoma [258].

\section{Sapienate and fatty acid desaturase 2 (FADS2) = $\Delta$-6-desaturase (D6D) (Fig. 1)}

The unique and abundant MUFA, sapienic acid (sapienate) is the most abundant FA in human sebum and among hair-bearing animals ([259] reviewed in [260]). Sapienate is an intermediate product of saturated palmitate to cis-8-octadeconoate [261]. FADS2 is a $\Delta$-6-desaturase (D6D) [260, 262-264] and was identified in human sebaceous glands where it converts palmitate into the MUFA, sapienate [260].

More recently it was shown that FADS2 signaling is used by cancer cells to produce sapienate as an alternate 


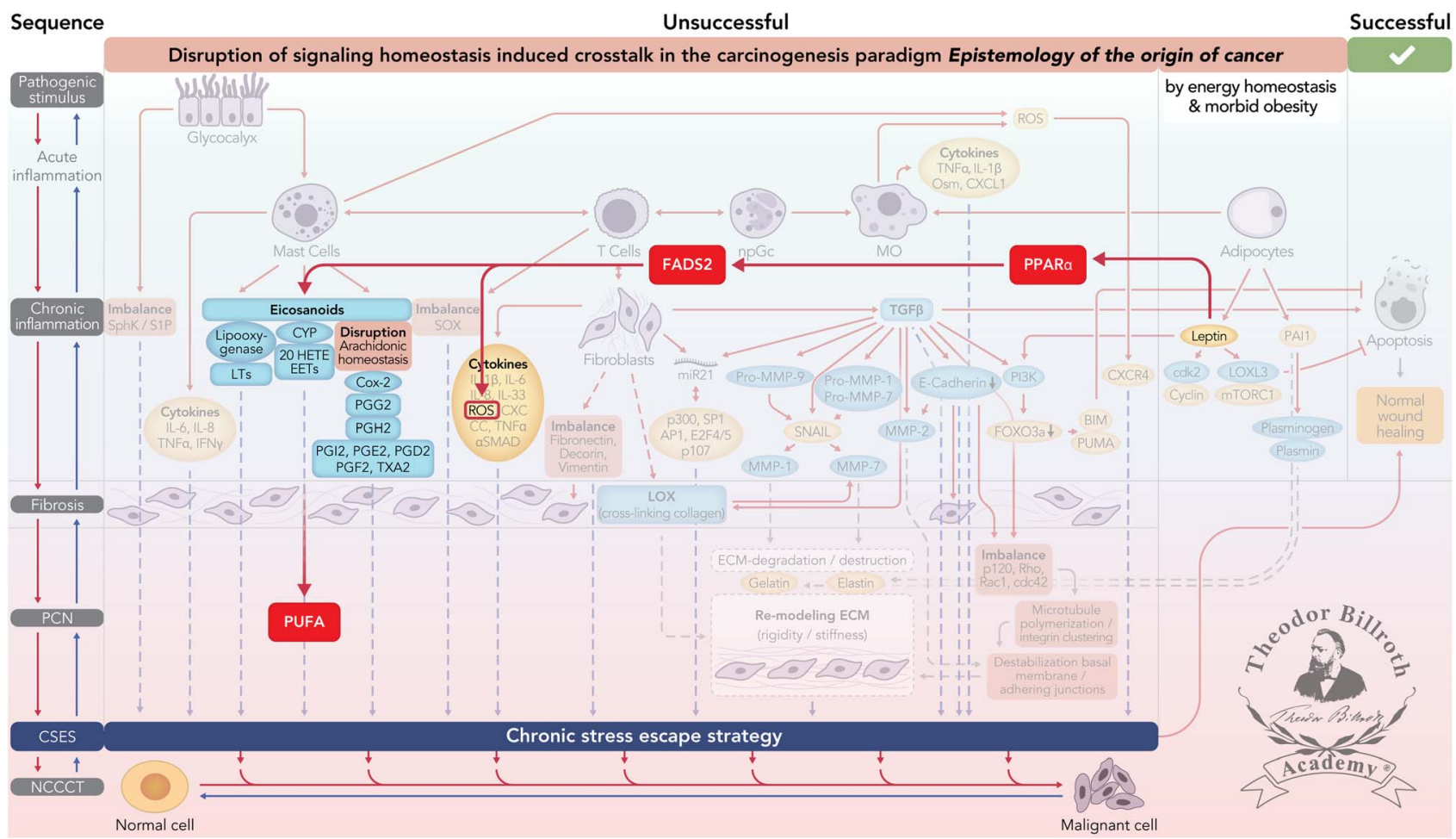

Figure 1. Simplified scheme of fatty acid desaturase 2 (FADS2) $=\omega$-6-desaturase (D6D) signaling in the disruption of signaling homeostasis induced crosstalk in the carcinogenesis paradigm "Epistemology of the origin of cancer" consisting of a six-step sequence (1) a pathogenic stimulus followed by (2) chronic inflammation from which develops (3) fibrosis with associated remodeling of the cellular microenvironment; and from these changes a (4) precancerous niche (PCN), a product of fibrosis, with remodeling by persistent inflammation, develops which triggers the deployment of (5) a chronic stress escape strategy and when this fails resolve it by (6) normal cell to cancerous cell transition (NCCCT) by PCN-induced cell matrix stress occurs. This figure was published as original illustration in paper 3 of this Special Issue - Disruption of homeostasis-induced signaling and crosstalk in the carcinogenesis paradigm "Epistemology of the origin of cancer" entitled "Chronic inflammation evoked by pathogenic stimulus during carcinogenesis" [145]. Furthermore, we point out, that to the complexity of the content of the Special Issue the original and/or modified version of the original illustration was republished within the following papers of the Special Issue: paper 5 "Microbiome and morbid obesity increase pathogenic stimulus diversity" [147], paper 6 "Precancerous niche (PCN), a product of fibrosis with remodeling by incessant chronic inflammation" [146], paper 7 "Metformin alters signaling homeostasis" [148], paper 8 "Transition from normal to cancerous cell by precancerous niche (PCN) induced chronic cell-matrix stress" [111] and paper 9 "NF- $k B$ signaling and crosstalk during carcinogenesis" [150]. Nomenclature Figure 1: The nomenclature common abbreviations are bold, followed by the common trivial names (if available) and (if available) by the name in accordance to the International Union of Pure and Applied Chemistry (IUPAC): FADS2: fatty acid desaturase 2, = $\omega$-6-desaturase (D6D); PPAR $\alpha$ : peroxisome proliferator-activated receptor-alpha; PUFA: polyunsaturated fatty acids; PCN: precancerous niche; CSES: chronic stress escape strategy; NCCCT: normal cell to cancerous cell transition; SphK: sphingosine kinase isoform; S1P: sphingosine-1-phosphate; IL-6: interleukin 6; IL-8: interleukin 8; TNF $\alpha$ : tumor necrosis factor alpha; IFN $\gamma$ : interferon gamma; ALOX: lipoxygenase, arachidonate lipoxygenase; ALOX12: 12-lipoxygenase, 12-LOX, 12S-LOX, arachidonate 12-lipoxygenase 12S type; ALOX5: 5-lipoxygenase, 5-LOX, arachidonate 5-lipoxygenase; 12-HETE: 12-hydroxyeicosatetraenoic acid; LTA4: leukotriene A4, 4-[(2S,3S)-3-[(1E,3E,5Z,8Z)-tetradeca-1,3,5,8-tetraenyl]oxiran-2-yl]butanoic acid; LTB4: leukotriene B4, (5S,6Z,8E,10E,12R,14Z)-5,12-dihydroxyicosa-6,8,10,14-tetraenoic acid; LTC4: leukotriene C4, (5S,6R,7E,9E,11Z,14Z)-6-[(2R)-2-[[(4S)-4-amino-4-carboxybutanoyl]amino]-3-(carboxymethylamino)-3-oxopropyl]sulfanyl-5-hydroxyicosa-7,9,11,14-tetraenoic acid; LTD4: leukotriene D4, (5S,6R,7E,9E,11Z,14Z)-6-[(2R)-2-amino-3-(carboxymethylamino)-3-oxopropyl]sulfanyl-5-hydroxyicosa-7,9,11,14-tetraenoic acid; LTE4: leukotriene E4, (5S,6R,7E,9E,11Z,14Z)-6-[(2R)-2-amino-2carboxyethyl]sulfanyl-5-hydroxyicosa-7,9,11,14-tetraenoic acid; 5-oxo-ETE: (6E,8Z,11Z,14Z)-5-oxoicosa-6,8,11,14-tetraenoic acid; Cox: cyclooxygenase; Cox-1: cyclooxygenase 1; Cox-2: cyclooxygenase 2; Cox-3: isoform of Cox-2 (therefore in brakes); PGG2: prostaglandin G2, (Z)-7-[(1S,4R,5R,6R)-5-[(E,3S)-3-hydroperoxyoct-1-enyl]-2,3-dioxabicyclo[2.2.1]heptan-6-yl]hept-5-enoic acid; PGH2: prostaglandin H2, (Z)-7-[(1S,4R,5R,6R)-5-[(E,3S)-3-hydroxyoct-1-enyl]-2,3-dioxabicyclo[2.2.1]heptan-6-yl]hept-5-enoic acid; PGFF2 $\alpha$ : prostaglandin F2 alpha, (Z)-7-[(1R,2R,3R,5S)-3,5-dihydroxy-2-[(E,3S)-3-hydroxyoct-1-enyl]cyclopentyl]hept-5-enoic acid; PGD2: prostaglandin D2, (Z)-7-[(1R,2R,5S)-5-hydroxy-2-[(E,3S)-3-hydroxyoct-1-enyl]-3-oxocyclopentyl]hept-5-enoic acid; PGE2: prostaglandin E2, (Z)-7-[(1R,2R,3R)-3-hydroxy-2-[(E,3S)-3-hydroxyoct-1-enyl]-5-oxocyclopentyl]hept-5-enoic acid; MDA: malondialdehyde, propanedial; TXA2: thromboxane A2, (Z)-7-[(1S,2S,3R,5S)-3-[(E,3S)-3-hydroxyoct-1-enyl]-4,6-dioxabicyclo [3.1.1]heptan-2-yl]hept-5-enoic acid; CYP*: cytochrome P450 isoforms; 20-OH-PGE2: 20-hydroxy prostaglandin E2; 20-HETE: 
metabolic pathway which the cells (ab)use it for membrane synthesis of cancer cells [265]. In accordance with a Figure published in this Special Issue [145], the FADS2 signaling fits in well with the thinking detailed in this Special Issue (Fig. 1).

\section{Transcriptional coactivator yes-associated protein (YAP) (Fig. 2)}

Another recent publication used heat maps generated by RNA transcriptomes and green fluorescent proteinlabeled $(\mathrm{GFP}+)$ B16F10 marked melanoma cells for metabolomic analysis. This study revealed that cancer cells use the production of bile acids in lymph node metastasis and a metabolic shift through transcriptional coactivator, yesassociated protein (YAP), as a mechanism to spread through lymph nodes [266]. It was shown, that inhibiting mammalian target of rapamycin complex 1 (mTORC1) results in the inhibition of YAP and its transcriptional coactivator with PDZ-binding motif (TAZ)-mediated liver cancer development [267]. Also, as shown in a figure published in this Special Issue [145], the YAP signaling fits well into our overall thought process discussed in this Special Issue (Fig. 2). Here, YAP can have ambivalent effects on apoptosis [268, 269].

A challenge in the future of science and cancer research will be using new technologies to develop specific anticancer therapies, which are not going to be easy as widely portrayed because of the need to integrate multi-sequence strategies to mitigate the disruption of homeostasis.

\section{Scope of new technologies}

There is an expectation that imaging at the molecular and atomic levels will provide new insights into cancer. The identification of virus particles at the atomic level, decoded by X-ray laser, was recently reported for the first time [270]. Imaging correction and enhancement by software of time-lapse microscopy will make previously hidden developmental steps in cells visible in time [271]. Magnetic nanoparticle magnetic resonance imaging (MRI) using ferumoxytol non-invasively visualized pancreatic inflammation in Type-1 diabetics [272] and nanomedicine technology might be a reliable tool to better understand physicochemical characteristics for use in the development of cancer pharmaceuticals [273]. Future mRNA imaging might also provide information for visualizing biochemical reactions which may create new opportunities for research [274]. For instance, such imaging tools might provide for a deeper understanding of our immune system and its interplay with various cell types, cytokines, and biochemical signaling.

The following signaling and crosstalk pathways might be elucidated using nano-imaging: immune cells promote activation and nuclear localization of inhibitor of nuclear factor kappa-B kinase 1 (IKK1, inhibitor of nuclear factor kappa-B kinase subunit alpha, IKK- $\alpha$ ) in prostatic epithelial tumor cells which can result into the suppression of maspin leading to metastasis $[275,276]$.

N-methyl-D-aspartate receptors (NMDA) are glutamate-gated cation channels with high calcium permeability playing roles in the biology of higher organisms [277]. Inhibiting NMDA by dextromethorphan (DXM) was shown to result in enhanced serum insulin concentrations and improved glucose tolerance [278]. The NF- $\kappa \mathrm{B}$ signaling and its influence by Metformin has been reviewed [150, 180]. A better and more complete understanding of Metformin's role in crosstalk pathways in diabetes could result in potential therapeutic use of Metformin against specific targets in certain cancers.

Pharmacological modulators of cation (calcium, sodium, potassium) and anion-permeable channels might impact cancer treatments [279] and pharmacogenomics might help further optimize patient sub-selection so as to better predict responses to cancer therapy [280].

The theory suggested to engineer gene-driven systems by Burt [281] and the discovery of the bacterial nuclease system named clustered regularly interspaced short palindromic repeats (CRISPR)/CRISPR-associated protein 9 (Cas9) [282] resulted in the false hope that cut-and-paste of any DNA sequence might cure any and all mutationcaused disease. As a cautionary tale, Chamber et al. revealed that rapid resistance to CRISPR gene engineering occurs, often in a single generation [283]. The editorial of the Journal was titled "The gene drive bubble: New realities" [284] to remind the scientific community about the necessity that such new technologies should be used with an abundance of caution and with realistic expectations of what they can and cannot deliver.

Figure 1. (continued) 20-hydroxyeicosatetraenoic acid, (5Z,8Z,11Z,14Z)-20-hydroxyicosa-5,8,11,14-tetraenoic acid; SOX: [sexdetermining region Y (Sry) box-containing] transcription factor family; IL- $\beta$ 1: interleukin beta 1 ; IL-33: interleukin 33 ; ROS: reactive oxygen species;CXC CC: chemokine receptors; $\alpha$ SMAD: alpha-smooth muscle actin; miR21: micro RNA-21; p300: protein 300 (p300-CBP coactivator family); SP1: specificity protein 1; AP1: activator protein 1; E2F4/5: cytoplasmic complex of Smad3, retinoblastoma-like protein 1 (P107, RBL1), E2F4/5 and D-prostanoid (DP1); p107: retinoblastoma-like protein 1, RBL1; TGF $\beta$ : transforming growth factor beta; Pro-MMP-9: pro-matrix metalloproteinase 9; Pro-MMP-1: pro-matrix metalloproteinase 1; Pro-MMP-7: pro matrix metalloproteinase 7; SNAIL: zinc finger protein SNAI1; MMP-1: matrix metalloproteinase 1; MMP-7: matrix metalloproteinase 7; MMP-2: matrix metalloproteinase 2; E-Cadherin: CAM 120/80 or epithelial cadherin, cadherin-1, epithelial cadherin; CXCL1: chemokine (C-X-C motif) ligand 1; Osm: oncostatin-M; PI3K: phosphatidylinositide 3-kinase; FOXO3a: forkhead box protein O3a; p120: catenin delta-1, protein 120; Rho: Ras homolog gene family, member A; Rac1: Rasrelated C3 botulinum toxin substrate 1; cdc42: cell division control protein 42 homolog; BIM: Bcl-2 interacting mediator of cell death; PUMA: BH3-only protein; CXCR4: C-X-C motif of chemokine receptor 4; cdk2: cyclin-dependent kinase 2; LOXL3: lysyl oxidase homolog 3; mTORc1: rapamycin complex 1; PAI1: Plasminogen activator inhibitor-1. 


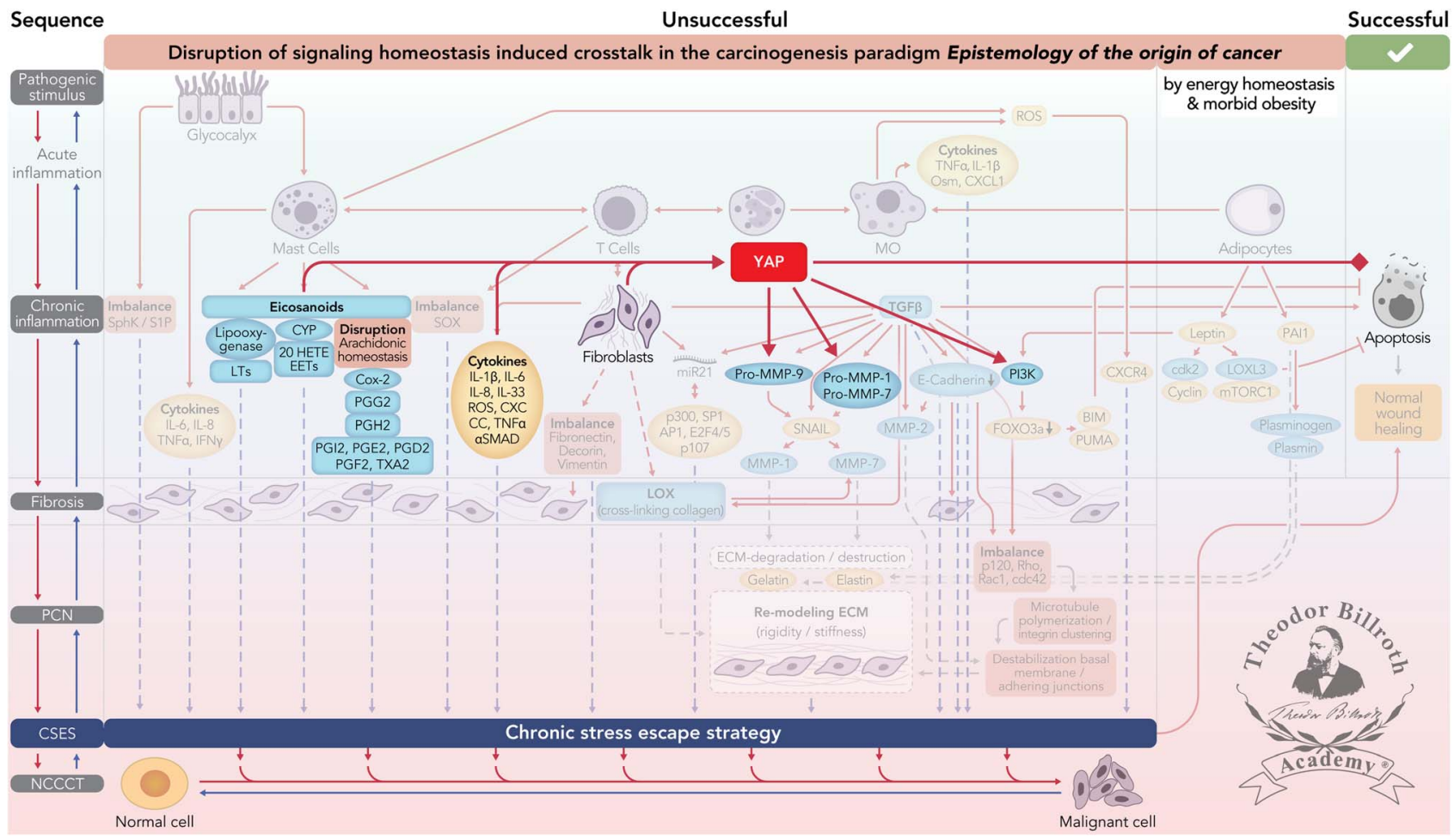

Figure 2. Simplified scheme of transcriptional coactivator yes-associated protein (YAP) signaling in the disruption of signaling homeostasis induced crosstalk in the carcinogenesis paradigm "Epistemology of the origin of cancer" consisting of a six-step sequence (1) a pathogenic stimulus followed by (2) chronic inflammation from which develops (3) fibrosis with associated remodeling of the cellular microenvironment; and from these changes a (4) precancerous niche (PCN), a product of fibrosis, with remodeling by persistent inflammation, develops which triggers the deployment of (5) a chronic stress escape strategy and when this fails resolve it by (6) normal cell to cancerous cell transition (NCCCT) by PCN-induced cell matrix stress occurs. This figure was published as original illustration in paper 3 of this Special Issue - Disruption of homeostasis-induced signaling and crosstalk in the carcinogenesis paradigm "Epistemology of the origin of cancer" entitled "Chronic inflammation evoked by pathogenic stimulus during carcinogenesis" [145] [Chronic inflammation 4open 2019]. Furthermore, we point out, that to the complexity of the content of the Special Issue the original and/or modified version of the original illustration was republished within the following papers of the Special Issue: paper 5 "Microbiome and morbid obesity increase pathogenic stimulus diversity" [147], paper 6 "Precancerous niche (PCN), a product of fibrosis with remodeling by incessant chronic inflammation" [146], paper 7 "Metformin alters signaling homeostasis" [148], paper 8 "Transition from normal to cancerous cell by precancerous niche (PCN) induced chronic cell-matrix stress" [111] and paper 9 "NF- $k B$ signaling and crosstalk during carcinogenesis" [150]. Here, YAP can have ambilavent effects on apoptosis [268, 269] why the connection between YAP and apoptosis ends at the stroke within the illustration with a rhombus. Nomenclature Figure 2: The nomenclature common abbreviations are bold, followed by the common trivial names (if available) and (if available) by the name in accordance to the International Union of Pure and Applied Chemistry (IUPAC): YAP: yes-associated protein; PCN: precancerous niche; CSES: chronic stress escape strategy; NCCCT: normal cell to cancerous cell transition; SphK: sphingosine kinase isoform; S1P: sphingosine-1-phosphate; IL-6: interleukin 6; IL-8: interleukin 8; TNF $\alpha$ : tumor necrosis factor alpha; IFN $\gamma$ : interferon gamma; ALOX: lipoxygenase, arachidonate lipoxygenase; ALOX12: 12-lipoxygenase, 12-LOX, 12S-LOX, arachidonate 12-lipoxygenase 12S type; ALOX5: 5-lipoxygenase, 5-LOX, arachidonate 5-lipoxygenase; 12-HETE: 12-hydroxyeicosatetraenoic acid; LTA4: leukotriene A4, 4-[(2S,3S)-3-[(1E,3E,5Z,8Z)-tetradeca-1,3,5,8-tetraenyl]oxiran-2-yl]butanoic acid; LTB4: leukotriene B4, (5S,6Z,8E,10E,12R,14Z)-5,12-dihydroxyicosa-6,8,10,14-tetraenoic acid; LTC4: leukotriene C4, (5S,6R,7E,9E,11Z,14Z)-6-[(2R)-2[[(4S)-4-amino-4-carboxybutanoyl]amino]-3-(carboxymethylamino)-3-oxopropyl]sulfanyl-5-hydroxyicosa-7,9,11,14-tetraenoic acid; LTD4: leukotriene D4, (5S,6R,7E,9E,11Z,14Z)-6-[(2R)-2-amino-3-(carboxymethylamino)-3-oxopropyl]sulfanyl-5-hydroxyicosa7,9,11,14-tetraenoic acid; LTE4: leukotriene E4, (5S,6R,7E,9E,11Z,14Z)-6-[(2R)-2-amino-2-carboxyethyl]sulfanyl-5-hydroxyicosa7,9,11,14-tetraenoic acid; 5-oxo-ETE: (6E,8Z,11Z,14Z)-5-oxoicosa-6,8,11,14-tetraenoic acid; Cox: cyclooxygenase; Cox-1: cyclooxygenase 1; Cox-2: cyclooxygenase 2; Cox-3: isoform of Cox-2 (therefore in brakes); PGG2: prostaglandin G2, (Z)-7[(1S,4R,5R,6R)-5-[(E,3S)-3-hydroperoxyoct-1-enyl]-2,3-dioxabicyclo[2.2.1]heptan-6-yl]hept-5-enoic acid; PGH2: prostaglandin H2, (Z)-7-[(1S,4R,5R,6R)-5-[(E,3S)-3-hydroxyoct-1-enyl]-2,3-dioxabicyclo[2.2.1]heptan-6-yl]hept-5-enoic acid; PGFF2 $\alpha$ : prostaglandin F2 alpha, (Z)-7-[(1R,2R,3R,5S)-3,5-dihydroxy-2-[(E,3S)-3-hydroxyoct-1-enyl]cyclopentyl]hept-5-enoic acid; PGD2: prostaglandin D2, (Z)-7-[(1R,2R,5S)-5-hydroxy-2-[(E,3S)-3-hydroxyoct-1-enyl]-3-oxocyclopentyl]hept-5-enoic acid; PGE2: prostaglandin E2, (Z)-7-[(1R,2R,3R)-3-hydroxy-2-[(E,3S)-3-hydroxyoct-1-enyl]-5-oxocyclopentyllhept-5-enoic acid; MDA: malondialdehyde, propanedial; TXA2: thromboxane A2, (Z)-7-[(1S,2S,3R,5S)-3-[(E,3S)-3-hydroxyoct-1-enyl]-4,6-dioxabicyclo[3.1.1]heptan-2-yl]hept-5-enoic acid; CYP*: cytochrome P450 isoforms; 20-OH-PGE2: 20-hydroxy prostaglandin E2; 20-HETE: 20-hydroxyeicosatetraenoic acid, (5Z,8Z,11Z,14Z)-20-hydroxyicosa-5,8,11,14-tetraenoic acid; SOX: [sex-determining region Y (Sry) box-containing] transcription factor family; IL- $\beta \mathbf{1}$ : interleukin beta 1 ; IL-33: interleukin 33; ROS: reactive oxygen species; CXC CC: chemokine receptors; 


\section{Developing targeted therapy not as easy as advertised}

Tacrolismus (FK506) binding protein 5 (FKBP51) is a $51 \mathrm{kDA}$ chaperon molecule and an endogenous cytosolic peptidyl-prolyl isomerase counted among the immunophilin protein family $[285,286]$ with others [287, 288]. Immunophilins had been described as receptor molecules for immunosuppressive drugs, such as cyclophilin 40 (CyP40), FK506-binding proteins FKBP51 and FK506-binding protein 4 (FKBP52), protein phosphatase 5 (PP5), and heat shock protein 90 (Hsp90) [289]. Its involvement in various signaling pathways and in diseases is incompletely understood at present but there is hope that an anti-FKB51 targeted therapy could be helpful for some diseases [290] but would need to be evaluated carefully in terms of potential effects on the signaling pathways in carcinogenesis because potential secondary adverse signaling effects could be created.

FKBP51 is associated with autophagy, psychiatric disorders, and diabetes. Experiments with cultured cells and FKBP51 knockdown mice showed that FKBP51 is involved in priming autophagy signaling and intracellular complexes and is actively required for setting the groundwork for antidepressants to work on the brain as evidenced by the observation that lacking FKBP51 in a mouse model abolished the antidepressant effects [291]. FKBP51 is associated with diabetes as it antagonizes the increase of phosphorylation of Akt substrate of $160 \mathrm{kDa}$ (AS160), glucose transporter type 4 (GLUT-4) expressions at the plasma membrane, and glucose uptake in skeletal myotubes [292]. Blocking FKBP51 could result in reducing or preventing diabetes as decreased FKBP51 levels are associated with reduced glucose intolerance and with maintaining or restoring metabolic homeostasis.

Anti-FKB51 targeting can also cause unwanted adverse effects. The role of glycogen synthase kinase $3 \beta$ (GSK-3 $\beta$ ) in carcinogenesis has been previously reviewed [146]. Inhibiting GSK-3 $\beta$ in glioblastoma cells is associated with induction of apoptosis and decrease of cell proliferation in vitro and in vivo [293]. However, there is a potential FKBP51/ GSK-3 $\beta$ interaction in cancer. FKBP51 increases the phosphorylation of GSK-3 $\beta$ at serine 9 (pGSK-3 $\beta S 9$ ) through its FK1 domain and also modifies GSK-3 $\beta$ 's heterocomplex formation via protein phosphatase 2 (PP2, PP2A) and the cyclin-dependent kinase 5 (cell division protein kinase 5 , CDK5) resulting in the inhibition of GSK-3 $\beta$ [294].

If FKBP51 could be blocked on a long-term basis, this might result in a pro-carcinogenic effect, as GSK- $3 \beta$ would be blocked, if to a lesser degree. We presume that potential anti-FKBP51 therapy approaches in diabetes and/or psychiatry would need to be evaluated carefully in terms of potential effects on the signaling pathways in carcinogenesis. Trying to correct the disruption of homeostasis on one side could well result in adverse signaling effects elsewhere.

\section{Anti-fibrotic strategies}

Helpful protocols to extract and assay LOX enzymes from tissue samples, cell culture cell layers, and media in the multifunctional LOX family have recently been published [295]. LOXL2 crosslinks collagen by mediating oxidative deamination of lysine residues [296, 297]. LOXL2 promotes dedifferentiation in PyMT tumor-derived cells together with reduced or delocalized E-cadherin [298]. LOXL2 was associated with increased levels of zinc finger protein SNAI1 (Snail) and various cytokines. Additionally, it was concluded that LOXL2 might be necessary for metastasis and facilitates the formation of PCN or metastatic niche formation by triggering the myeloid progenitor $\mathrm{CD} 11 \mathrm{~b}+/ \mathrm{Gr} 1+$ cell population but that this effect was independent "of its potential ability to modify ECM stiffness and collagen organization". LOXL2 represses the canonical Notch homolog 1 (Notch1) pathway and correlates negatively in premalignant tumors [299].

Fibrosis was shown to be attenuated by "combined inhibition of LOXL2 and TGF- $\beta$ type I receptor (TBRI) activities by trihydrophenolics" [300]. Blocking LOXL2 in thioacetamide (TAA)-induced fibrosis showed attenuation of both parenchymal and biliary fibrosis as well as reversal of fibrosis [301].

Uterine fibroids are seen as non-cancerous growths [302] with a low risk of $0.96 \%$ out of 229,536 adult women having unexpected uterine cancer [303]. An anti-fibrotic approach using atorvastatin which inhibits cell proliferation in a dose and time-dependent manner plus stimulating apoptosis by inducing caspase-3 activation, up-regulating Bcl-2 interacting mediator of cell death (Bim) and down-regulating B-cell lymphoma 2 (Bcl-2) and suppressing phosphorylation of ERK1/ 2 and c-Jun N-terminal kinase (JNK) was reported [304].

Figure 2. (continued) $\alpha$ SMAD: alpha-smooth muscle actin; miR21: micro RNA-21; p300: protein 300 (p300-CBP coactivator family); SP1: specificity protein 1; AP1: activator protein 1; E2F4/5: cytoplasmic complex of Smad3, retinoblastoma-like protein 1 (P107, RBL1), E2F4/5 and D-prostanoid (DP1); p107: retinoblastoma-like protein 1, RBL1; TGF $\beta$ : transforming growth factor beta; Pro-MMP-9: pro-matrix metalloproteinase 9; Pro-MMP-1: pro-matrix metalloproteinase 1; Pro-MMP-7: pro matrix metalloproteinase 7; SNAIL: zinc finger protein SNAI1; MMP-1: matrix metalloproteinase 1; MMP-7: matrix metalloproteinase 7; MMP-2: matrix metalloproteinase 2; E-Cadherin: CAM 120/80 or epithelial cadherin, cadherin-1, epithelial cadherin; CXCL1: chemokine (C-X-C motif) ligand 1; Osm: oncostatin-M; PI3K: phosphatidylinositide 3-kinase; FOXO3a: forkhead box protein O3a; p120: catenin delta-1, protein 120; Rho: Ras homolog gene family, member A; Rac1: Ras-related C3 botulinum toxin substrate 1; cdc42: cell division control protein 42 homolog; BIM: Bcl-2 interacting mediator of cell death; PUMA: BH3-only protein; CXCR4: C-X-C motif of chemokine receptor 4; cdk2: cyclin-dependent kinase 2; LOXL3: lysyl oxidase homolog 3; mTORc1: rapamycin complex 1; PAI1: Plasminogen activator inhibitor-1. 


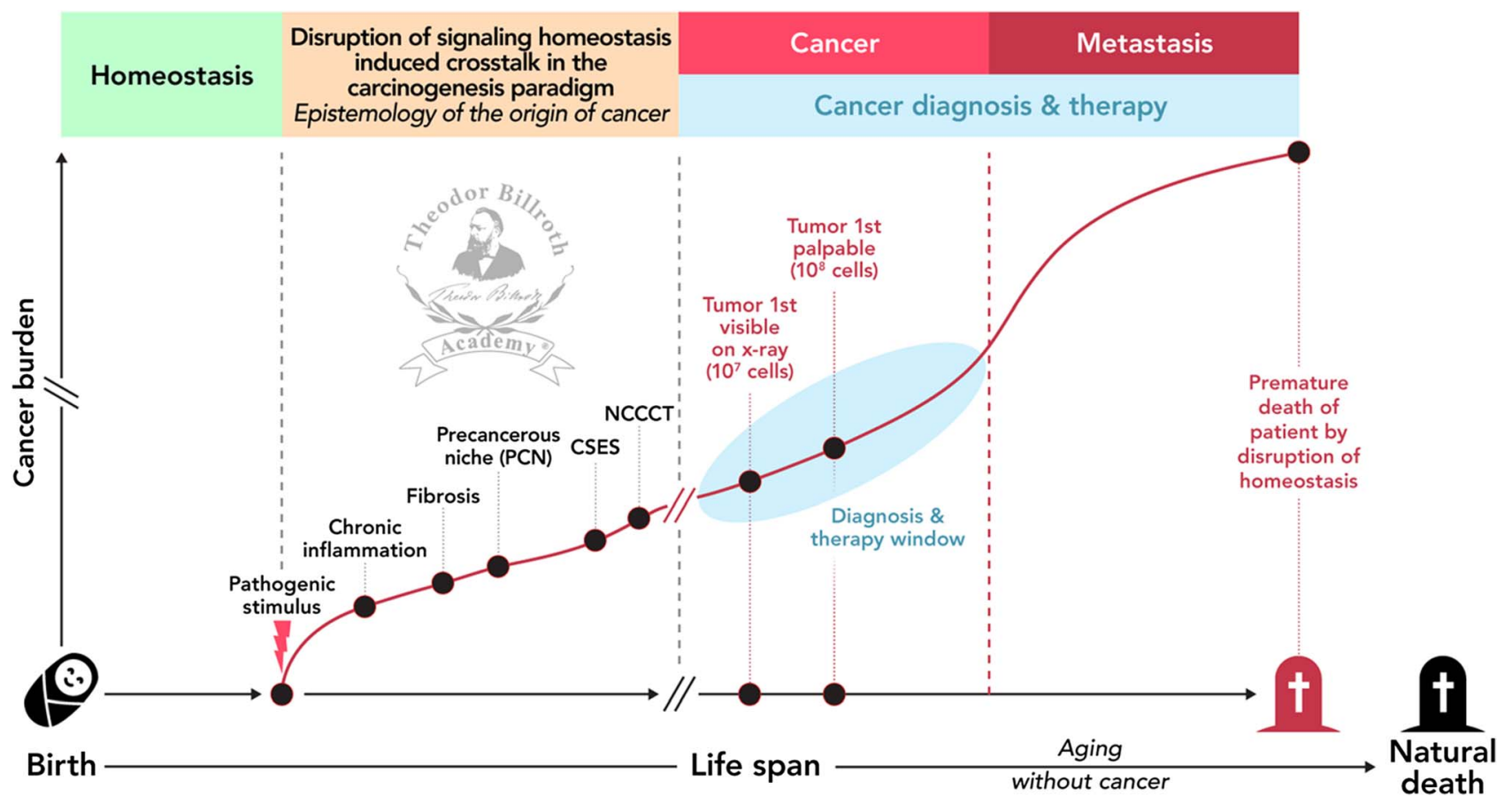

Figure 3. Cancer burden in regard to homeostasis and the disruption of signaling homeostasis induced crosstalk in the carcinogenesis paradigm "Epistemology of the origin of cancer". Explanation numbers: A tumor nodule is reported to be first detectable by X-ray imaging when it has $10^{7}$ cells [330] which was earlier $10^{8}$ cells [331]. The average number of cells in a tumor when it is first palpable was reported to be $10^{9}$ cells in 2002 [331] which approximately accounts for a tumor with $1 \mathrm{~g}$ [332]. As it was also reported to be $10^{6}$ cells in 1943 [333], we decided to decrease this number for the illustration by $1 \log$ only to $10^{8}$ cells.

Inhibiting AGTR1 with losartan, in combination with the chemotherapy regime FOLFIRINOX (F-NOX), in locally advanced pancreatic cancer resulted in higher complete macroscopic and microscopic cancer resection rates (R0-resections) [305]. Using losartan in pancreatic ductal adenocarcinoma mice treated with losartan $(70 \mathrm{mg} / \mathrm{kg})$ or saline (control vehicle) showed an increase of fractional blood volume and vessel size index plus an increase in the intratumoral uptake of 18Fluor-labelled 5-fluorouracil $\left({ }^{18} \mathrm{~F}-5 \mathrm{FU}\right)$ by $53 \%$ in micro-positron emission tomography (PET) [306]. The application of the monoclonal antibody simtuzumab failed to provide evidence of a therapeutic effect in idiopathic pulmonary fibrosis [307]. We consider that this is related to the existence of various alternative splicing isoforms [308] that could explain why a monoclonal antibody to LOXL2 alone might not result into the necessary clinical anti-fibrotic effect.

In this regard it may be relevant that intranasal losartan decreases perivascular beta amyloid, chronic inflammation, and the decline of neurogenesis in hypertensive rats [309]. Even in AD, and other chronic diseases the sequences of pathogenic stimulus followed by unresolved chronic inflammation and fibrosis are important.

The stroma of human pancreatic tumors expresses the vitamin D receptor (VDR) and treatment with a vitamin D3 derivative "the VDR ligand calcipotriol markedly reduced markers of inflammation and fibrosis in pancreatitis and human tumor stroma" with an improvement in gemcitabine responsiveness [310]. To our knowledge, there are no ongoing and/or planned cancer trials combining antifibrotic agents together with calcipotriol and/or antiinflammatory agents.

Although our current understanding is limited, it would be of interest to know how the quantity of cross-links occurs, as well the "cross-links-types" and how these influence the stroma and the subsequent fate of tumor [300, $311,312]$.

In vivo studies in two complementary genetic mouse models with mammary gland specific deletion or overexpression of LOXL2 in the PyMT breast cancer model have yielded promising results. The PyMT model mimics many processes found in human breast cancer progression generating highly aggressive tumors that metastasize to the lung within 3-4 months [313]. LOXL2 deletion in primary tumors resulted in a dramatic decrease of lung metastases while its overexpression produced increased lung metastases [298].

\section{Cautiously optimistic}

We may have overestimated the importance of signaling in experiments in so far as static measurements cannot reveal what occurs over long periods. "Recognition of risk markers that reliably predict disease" is considered important for early cancer screening [314] but methodological approaches need to be taken into account: different signaling markers have different levels to be measured at different 


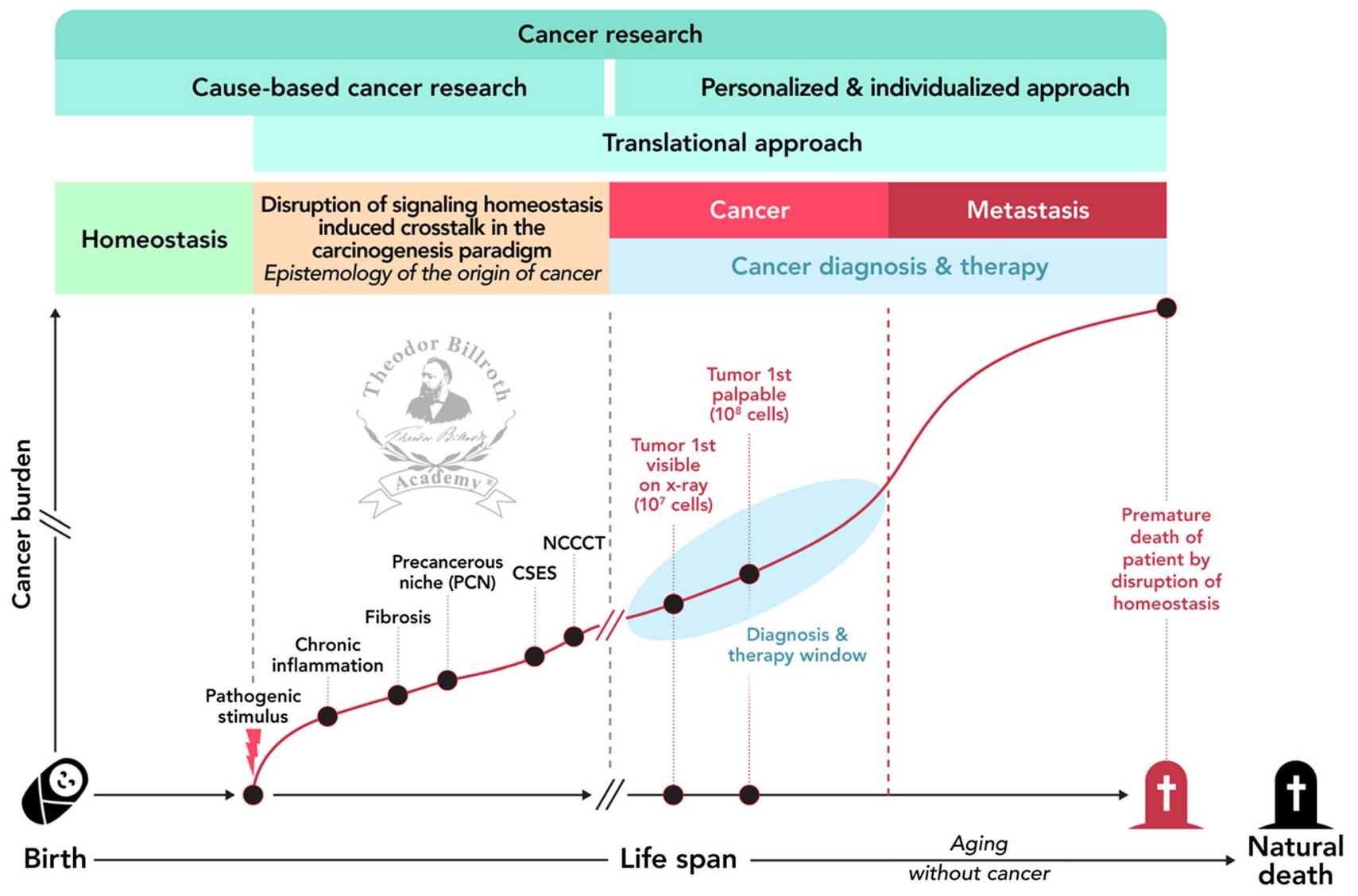

Figure 4. Cancer research strategies and cancer burden within the Disruption of signaling homeostasis induced crosstalk in the carcinogenesis paradigm "Epistemology of the origin of cancer". Explanation numbers: A tumor nodule is reported to be first detectable by X-ray imaging when it has $10^{7}$ cells [330] which was earlier $10^{8}$ cells [331]. The average number of cells in a tumor when it is first palpable was reported to be $10^{9}$ cells in 2002 [331] which approximately accounts for a tumor with $1 \mathrm{~g}$ [332]. As it was also reported to be $10^{6}$ cells in 1943 [333], we decided to decrease this number for the illustration by $1 \log$ only to $10^{8}$ cells.

locales within the tumor microenvironment, as for example CK18 at $2 \mathrm{~cm}$ sites was higher than at the $5 \mathrm{~cm}$ site [315]. In addition, disease itself may induce secondary changes in the expressions of potential biomarkers as was shown in hypertension-induced elevation of connexin 45 (Cx45), and which may affect communication between vascular smooth muscle cells (VSMCs) [316]. The disruption of homeostasis reveals itself through many different facets.

Investigating solid materials at around $-243{ }^{\circ} \mathrm{C}$ using an ultrasound laser pulse revealed that atoms re-arrange themselves within 350 billionths of a second [317]. Furthermore, an as yet unrecognized helix dissociation pathway which occurred within milliseconds was recently reported [318]. mRNA imaging needs to consider the following: $80 \%$ of RNAs have a median half-life of "around 2 min" and some $20 \%$ for between 5 and 20 min [319]. RNA collected over the last few decades did not discriminate between RNA separated and collected within 2 min versus between 5 and $20 \mathrm{~min}$ or even longer. Quality surrogate variable analysis (qSVA) in RNA-seq as a framework for removing confounding by RNA quality and replication resulted in a three-fold (300\%) improvement in replication compared with previous approaches [320].

\section{Summary (Figs. 3-5)}

This Special Issue "Disruption of signaling homeostasis induced crosstalk in the carcinogenesis paradigm 'Epistemology of the origin of cancer" " [111, 113, 144-150] provides evidence that the six-step sequence $[5,6]$ of events explains carcinogenesis for some $80 \%$ of all cancers. This sequences include (1) a pathogenic stimulus followed by (2) chronic inflammation, from which develops (3) fibrosis with associated remodeling in the cellular microenvironment. From these changes a (4) pre-cancerous niche develops, which triggers the deployment of (5) a chronic stress escape strategy, and when this fails to resolve, and (6) the transition of a normal cell to a cancer cell occurs. These six steps, and the detailed analysis provided in this Special Issue, show that cancer originates, at its essence, from a disruption of homeostasis, the biological phenomenon that maintains cellular function within a given range that defines health.

Although underpinned by many observations including a recent case-control study showing that exposure to bovine leukemia virus is linked to human breast cancer [321], the complexity of signaling and crosstalk is vast as re-activation 


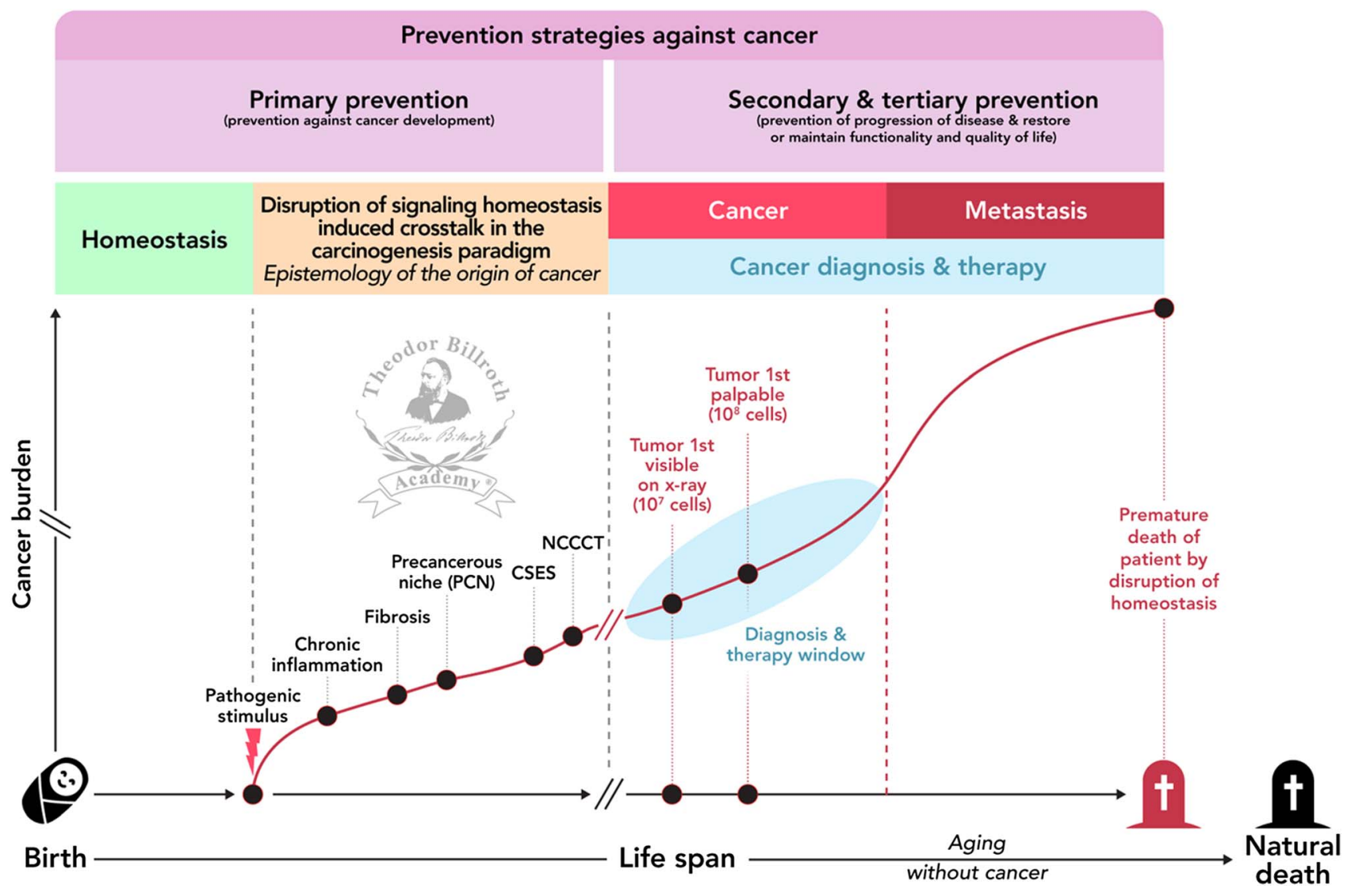

Figure 5. Prevention strategies and cancer burden in regard to homeostasis and the disruption of signaling homeostasis induced crosstalk in the carcinogenesis paradigm "Epistemology of the origin of cancer". Explanation numbers: A tumor nodule is reported to be first detectable by X-ray imaging when it has $10^{7}$ cells [330] which was earlier $10^{8}$ cells [331]. The average number of cells in a tumor when it is first palpable was reported to be $10^{9}$ cells in 2002 [331] which approximately accounts for a tumor with $1 \mathrm{~g}$ [332]. As it was also reported to be $10^{6}$ cells in 1943 [333], we decided to decrease this number for the illustration by 1 log only to $10^{8}$ cells.

of latent subclinical inflammation can occur [322]. This may also explain why radiotherapy, after complete tumor resection, can trigger a future PCN and subsequent cancer.

The significance of these findings is evidenced from data that show that retroviruses can create endogenous forms on infiltration into the germline cells of their hosts as the ancestor leukemia delta retrovirus group found in bats are between 20 and 45 million years old [323]. There is little doubt that our understanding of signaling pathways in nature and biology is incomplete. However, this may be viewed in light of the fact that some $99.9 \%$ of all somatic mutations that occur within the coding regions of the genome are not fully understood $[8,9]$.

Furthermore, despite anti-vaccine options eliminating the primary pathogenic stimulus, it is now better appreciated that "curing" cancer by one therapy will not occur in the near future and that multi-step anti-cancer treatments will be necessary. This is underpinned by the knowledge and evidence in regard to therapies, such as reversion of Helicobacter pylori ( $H$. pylori) induced chronic gastric inflammation and metaplasia which can be accomplished by eradication as a 10-year-follow-up study showed [324, 325].
Additionally, vaccines and anti-fibrotic options have been extensively reviewed. However, to focus on fibrosis alone is not enough. For some 100 years, we have known that there is an inverse ratio of the rate of growth of connective tissue to animal age and a larger amount of connective tissue is produced in young animals and humans which were reproducible for cultured fibroblasts [326-328]. This knowledge needs to be considered in any anti-fibrosis therapy.

Although future studies to investigate the associations of ultra-processed food intake with its influence on the microbiome, morbid obesity, and cancer incidences are warranted, a recent study from the French NutriNet-Santé cohort between 2009 and 2017 investigating 104,980 participants, reported "a $10 \%$ increase in the proportion of ultraprocessed foods in the diet was associated with a statistically significant increase of greater than $10 \%$ in risks of overall and breast cancer" [329].

Despite the need to be cautious in evaluating these findings, they together with the extensive discussions published here [111, 113, 144-150], provide evidence that a much more nuanced view on carcinogenesis is needed. The sixstep sequence is much more plausible than a mono-causal carcinogenesis paradigm. The assumptions that genetic 
alterations (somatic mutation theory, aneuploidy theory) or cellular metabolism with a consequent energy switch (Warburg theory) alone might explain the etiology of the majority of cancers is not enough to explain cancer as a disease.

Thus, we should not postulate that the majority of cancers originate in genetics and certainly not causally by somatic mutations $[9,113]$. It has been previously pointed out that "Imaging $\boldsymbol{A}$ World Without Cancer is clearly a vision" and that "For its realization, a global personalized and individualized anticancer strategy could be fundamental as both could integrate patient- and tumor-associated achievements in research in an adoptable and cost-sensitive manner" [7]. As mentioned earlier "In order to meet the challenges in getting there, any newly proposed anticancer strategy must integrate a personalized treatment outcome approach" [7].

Figure 3 summarizes the cancer burden in regard to homeostasis and the disruption of signaling homeostasis induced crosstalk in the carcinogenesis paradigm "Epistemology of the origin of cancer"; here a tumor nodule is reported to be first detectable by X-ray imaging when it has $10^{7}$ cells [330] which was earlier reported to be $10^{8}$ cells [331]. The average number of cells in a tumor when it is first palpable was reported to be $10^{9}$ cells in 2002 [331] which approximately accounts for a tumor with $1 \mathrm{~g}$ [332]. As it was also reported to be $10^{6}$ cells in 1943 [333], we decided to decrease this number for the actual illustration by 1 $\log$ only to $10^{8}$ cells.

By extension, we suggest to differentiate cancer research into cause-based, personalized and individualized approaches as well as in translational approaches (Fig. 4). This would include differentiating primary prevention against cancer development versus secondary and tertiary preventive strategies to prevent progression of the disease and to restore or maintain functionality and quality of life (Fig. 5).

As reported recently "Although science belongs to no one - and to everyone, property (science) obliges" and "Our responsibility as scientists is to insure that the generations that follow us cannot write, Science and research, especially within biotechnology and molecular biology, promised so much and delivered so little" [334]. This knowledge provides various opportunities for science and research as well as for primary preventive interventions on the onset of cancer as a disease and, to mitigate metastases.

With respect to the provided complex pre-clinical in vitro and in vivo clinical and epidemiological evidence provided within this Special Issue, the six-sequence carcinogenesis paradigm cannot be denied. Our long cognition journey was driven to understand this complicated interwoven multi-step process to describe how a cancer cell develops. Truly, this is a huge challenge to connect and overview the various signaling crosstalk on different levels and without question, many questions remain to be answered with additional experiments and new findings elaborated. We are hopeful that our thinking and scientific work stimulates further thinking in cancer and ultimately leads to benefits for those who deserve it the most: cancer patients and their relatives.

\section{Nomenclature of abbreviations}

5-HETE 5-Hydroxyeicosatetraenoic acid

12-HETE (5E,8Z,10Z,14Z)-12-hydroxyicosa$5,8,10,14$-tetraenoic acid

12(S)-HETE 12(steoreoisomer)-hydroxyeicosatetraenoic acid

12(R)-HETE 12("R" stereoisomer)-hydroxyeicosatetraenoic acid

15-HETE 15-Hydroxyeicosatetraenoic acid, (5Z,8Z, 11Z,13E)-15-hydroxyicosa-5,8,11,13-tetraenoic acid

${ }^{18} \mathrm{~F}-5 \mathrm{FU} \quad$ 18Fluor-labelled 5-fluorouracil

AA

$\mathrm{AD}$

AGTR1 Angiotensin II receptor type 1, $\mathrm{AT}_{1}$-receptor

Akt Protein kinase B (PKB)

pAkt Phosphorylated protein kinase B

ALA $\quad \alpha$-Linolenic acid, (9Z,12Z,15Z)-octadeca9,12,15-trienoic acid

ALDH1A1 Aldehyde dehydrogenase 1 family member A1

AMP

AMPK

ANGII

AP-2

APC

AS160

ATM

Bcl-2

BDPA

Bim

$\mathrm{BPH}$

BRCA

CCL2

CD44

CHK2

Co-IP

CRE

CREB

c-Rel

Cas9

CDK5

CRISPR Adenosine 3',5'-monophosphate AMP-activated protein kinase

Angiotensin II

Activating protein 2

Adenomatous polyposis coli

Akt substrate of $160 \mathrm{kDa}$

ATM serine/threonine protein kinase

B-cell lymphoma 2

Osbond acid, (All-Z)-4,7,10,13,16-docosapentaenoic acid

Bcl-2 interacting mediator of cell death

Benign prostatic hyperplasia

Breast cancer type protein

Chemokine (C-C motif) ligand 2

Cluster of differentiation 44

Checkpoint kinase 2

Co-immunoprecipitation

cAMP response element

cAMP response element (CRE)-binding protein 1

Proto-oncogene c-Rel

CRISPR-associated protein 9

Cyclin-dependent kinase 5, cell division protein kinase 5

$\mathrm{CyP} 40$

$\mathrm{Cx} 45$

DesA

DGLA
Clustered regularly interspaced short palindromic repeats

Cyclophilin 40

Connexin 45

Bacterial desaturase

Dihomo gamma-linolenic acid 


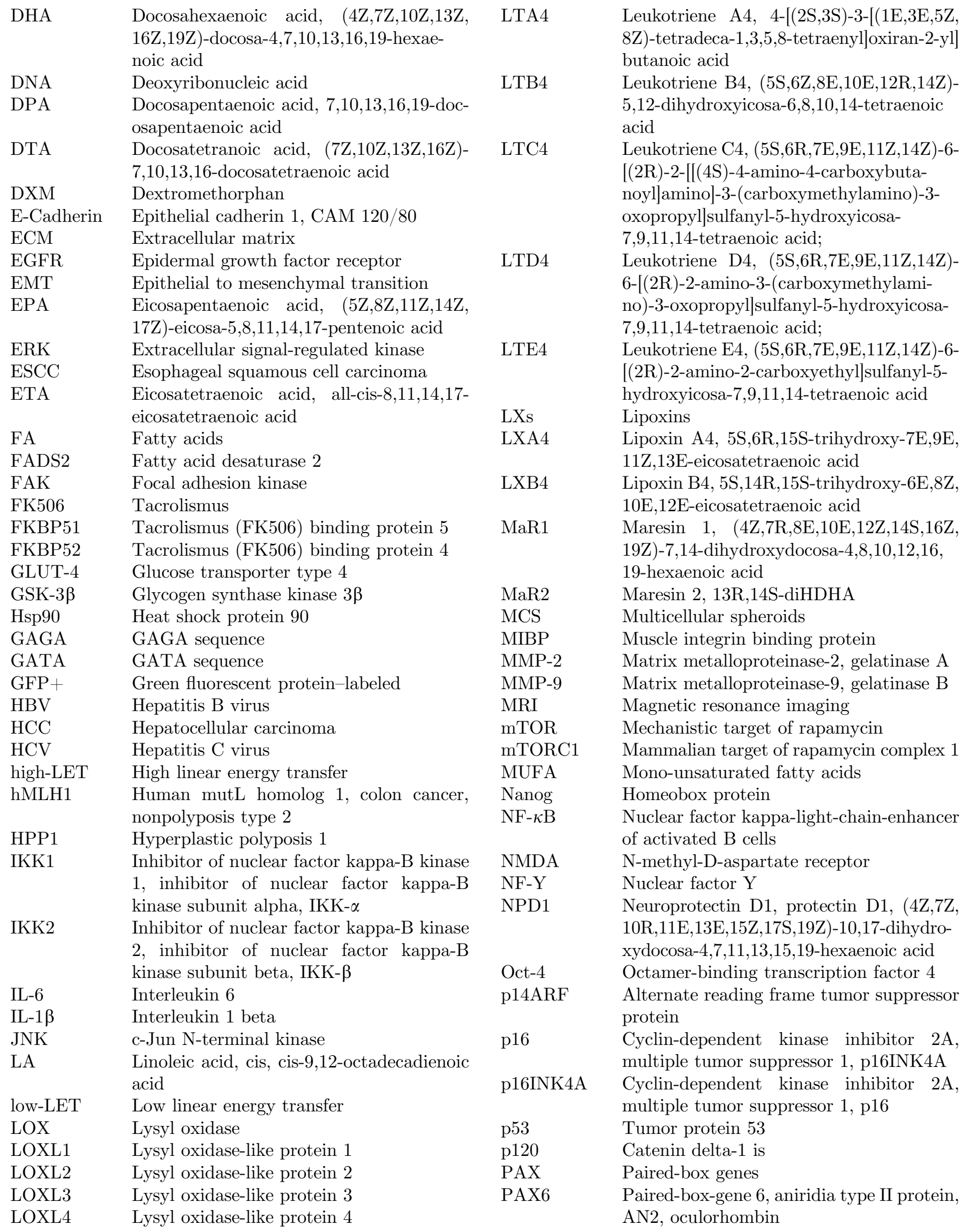




\begin{tabular}{|c|c|}
\hline $\mathrm{PCN}$ & Pre-cancerous niche \\
\hline $\mathrm{PD}$ & Paired domain \\
\hline PET & Positron emission tomography \\
\hline PGG2 & $\begin{array}{l}\text { Prostaglandin G2, (Z)-7-[(1S,4R,5R,6R)-5- } \\
\text { [(E,3S)-3-hydroperoxyoct-1-enyl]-2,3-diox- } \\
\text { abicyclo[2.2.1]heptan-6-yl]hept-5-enoic acid }\end{array}$ \\
\hline PGH2 & $\begin{array}{l}\text { Prostaglandin H2, (Z)-7-[(1S,4R,5R,6R)- } \\
5 \text {-[(E,3S)-3-hydroxyoct-1-enyl]-2,3-dioxa- } \\
\text { bicyclo[2.2.1]heptan-6-yl]hept-5-enoic acid }\end{array}$ \\
\hline PI3K & Phosphoinositide 3-kinase \\
\hline PP2 & Protein phosphatase 2, PP2A \\
\hline PP2A & Protein phosphatase $2, \mathrm{PP} 2$ \\
\hline PP5 & Protein phosphatase 5 \\
\hline pPI3K & Phosphorylated phosphoinositide 3-kinase \\
\hline $\operatorname{PPAR} \alpha$ & $\begin{array}{l}\text { Peroxisome proliferator-activated recep- } \\
\text { tor-alpha }\end{array}$ \\
\hline qSVA & Quality surrogate variable analysis \\
\hline RFX1 & Regulatory factor X1 \\
\hline RVs & Resolvins \\
\hline RvD1 & $\begin{array}{l}\text { Resolvin D1, (4Z,7S,8R,9E,11E,13Z,15E, } \\
\text { 17S,19Z)-7,8,17-trihydroxydocosa-4,9,11, } \\
\text { 13,15,19-hexaenoic acid }\end{array}$ \\
\hline RvD3 & $\begin{array}{l}\text { Resolvin D3, (4S,5E,7E,9E,13Z,15E,17R, } \\
\text { 19Z)-4,11,17-trihydroxydocosa-5,7,9,13, } \\
\text { 15,19-hexaenoic acid }\end{array}$ \\
\hline RvD4 & $\begin{array}{l}\text { Resolvin D4, (4S,6E,8E,10E,13E,15Z,17S, } \\
\text { 19Z)-4,5,17-trihydroxydocosa-6,8,10,13, } \\
\text { 15,19-hexaenoic acid }\end{array}$ \\
\hline RvD5 & $\begin{array}{l}\text { Resolvin D5, (5Z,7S,8E,10Z,13Z,15E,17S, } \\
\text { 19Z)-7,17-dihydroxydocosa-5,8,10,13,15, } \\
\text { 19-hexaenoic acid }\end{array}$ \\
\hline RvD6 & $\begin{array}{l}\text { Resolvin D6, (4S,5E,7Z,10Z,13Z,15E, } \\
\text { 17S,19Z)-4,17-dihydroxydocosa-5,7,10,13, } \\
\text { 15,19-hexaenoic acid }\end{array}$ \\
\hline SB-AC & Small bowel adenocarcinoma \\
\hline SCD1 & $\begin{array}{l}\text { stearoyl-CoA desaturase- } 1, \Delta-9 \text { desaturase } \\
\text { (D9D) }\end{array}$ \\
\hline Snail & Zinc finger protein SNAI1 \\
\hline Sox-2 & Sex determining region $\mathrm{Y}$ (SRY)-box 2 \\
\hline SPARC & Secreted protein acidic and rich in cysteine \\
\hline SPMs & Specialized pro-resolving lipid mediators \\
\hline SREBP-1 & Sterol regulatory element-binding protein 1 \\
\hline SRF & Serum response factor \\
\hline SRY & Sex determining region $\mathrm{Y}$ \\
\hline STAT3 & $\begin{array}{l}\text { Signal transducer and activator of tran- } \\
\text { scription } 3\end{array}$ \\
\hline STAT6 & $\begin{array}{l}\text { Signal transducer and activator of tran- } \\
\text { scription } 6\end{array}$ \\
\hline $\mathrm{T} 3$ & Triiodothyronine \\
\hline $\mathrm{T} \beta \mathrm{RI}$ & $\begin{array}{l}\text { Transforming growth factor beta type I } \\
\text { receptor }\end{array}$ \\
\hline TAA & Thioacetamide \\
\hline TAZ & $\begin{array}{l}\text { Transcriptional coactivator of YAP with } \\
\text { PDZ-binding motif }\end{array}$ \\
\hline TCA & Tricarboxylic acid \\
\hline TGF- $\beta 1$ & Transforming growth factor beta 1 \\
\hline
\end{tabular}

TGs

SMT

VDR

VSMC

$\omega-3-P U F A$

$\omega-6-P U F A$

WES

XP
Triglycerides

Somatic mutation theory

Vitamin D receptor

Vascular smooth muscle cell

n-3 polyunsaturated fatty acid, $\omega-3$

n-6 Polyunsaturated fatty acid, $\omega-6$

Whole exome sequencing

XERODERMA pigmentosum

\section{Acknowledgments}

The manuscripts of this Special Issue were supported by the Theodor-Billroth-Academy ${ }^{\circledR}\left(\mathrm{TBA}^{\circledR}\right)$ and INCORE, (International Consortium of Research Excellence) of the $\left(\mathrm{TBA}^{\circledR}\right)$. We express our gratitude to the discussions on the web group of the Theodor-Billroth-Academy ${ }^{\circledR}$ $\left(\mathrm{TBA}^{\circledR}\right)$ on LinkedIn, the exchange with scientists at Researchgate.com, as well as personal exchanges with distinguished colleagues who stimulated our thinking all named individually earlier in publications - we thank each one. We want to express our thanks to the excellent peerreviews we received by the reviewers and the guest editor.

\section{Conflict of interest}

The author reports the following conflict of interest: Björn LDM Brücher is Editor-in-Chief in Life SciencesMedicine of 4open by EDP Sciences. Ijaz S. Jamall is Senior Editorial Board member in Life Sciences-Medicine of 4open by EDP Sciences. The authors, of their own initiative, suggested to the Managing Editorial to perform a transparent peer-review of their submittals. Neither author took any action to influence the standard submission and peer-review process, and report no conflict of interest. The authors alone are responsible for the content and writing of the manuscript of this Special Issue. This manuscript contains original material that has not previously been published. Both authors contributed to the discussion on its contents and approved the manuscript.

\section{References}

1. Calaf GM, Zepeda AB, Castillo RL, Figueroa CA, Arias C, Figueroa E, Farías JG (2015), Molecular aspects of breast cancer resistance to drugs (Review). Int $\mathrm{J}$ Oncol 47, 2, 437-445. https://doi.org/10.3892/ijo.2015.3055.

2. Kimberly L (2015), Global Cancer Spending Reaches $\$ 100 B$, US News, Washington, DC, May, 5. https://www.usnews. com/news/blogs/data-mine/2015/05/05/global-cancerspending-reaches-100b.

3. National Cancer Institue (NCI) (2018), Most recent reported fiscal year budget, NCI, Bethesda, MD, December, 20. https://www.cancer.gov/about-nci/budget/fact-book/ data/recent-fiscal-year.

4. Begum M, Lewison G, Lawler M, Sullivan R (2018), Mapping the European cancer research landscape: an 
evidence base for national and Pan-European research and funding. Eur J Cancer 100, 2018, 75-84. https://doi.org/ 10.1016/j.ejca.2018.04.017.

5. Brücher BLDM, Jamall IS (2014), Epistemology of the origin of cancer: a new paradigm. BMC Cancer 14, 331, 1-15. https://doi.org/10.1186/1471-2407-14-331.

6. Brücher BLDM, Jamall IS (2014), Cell-Cell communication in tumor microenvironment, carcinogenesis and anticancer treatment. Cell Physiol Biochem 34, 213-243. https://doi. org $/ 10.1159 / 000362978$.

7. Brücher BLDM, Lyman G, van Hillegersberg R, Pollock RE, Lordick F, Yang HK, Ushijima T, Yeoh KG, Skricka T, Polkowski W, Wallner G, Verwaal V, Garofalo A, D'Ugo D, Roviello F, Steinau HU, Wallace TJ, Daumer M, Maihle N, Reid TJ III, Ducreux M, Kitagawa Y, Knuth A, Zilberstein B, Steele SR, Jamall IS (2014), Imagine a world without cancer. BMC Cancer 14, 186, 1-8. https://doi.org/10.1186/ 1471-2407-14-186.

8. Brücher BLDM, Li Y, Schnabel P, Daumer M, Wallace TJ, Kube R, Zilberstein B, Steele S, Voskuil JL, Jamall IS (2016), Genomics, microRNA, epigenetics, and proteomics for future diagnosis, treatment and monitoring response in upper GI cancers. Clin Transl Med 5, 1, 1-16. https://doi. org/10.1186/s40169-016-0093-6.

9. Brücher BLDM, Jamall IS (2016), Somatic mutation theoryWhy it's wrong for most cancers. Cell Physiol Biochem 38, 5, 1663-1680. https://doi.org/10.1159/000443106.

10. Zhu M, Lu T, Jia Y, Luo X, Gopal P, Li L, Odewole M, Renteria V, Singal AG, Jang Y, Ge K, Wang SC, Sorouri M, Parekh JR, MacConmara MP, Yopp AC, Wang T, Zhu H (2019), Somatic mutations increase hepatic clonal fitness and regeneration in chronic liver disease. Cell 177, 3, 608-621.e12. https://doi.org/10.1016/j.cell.2019.03.026.

11. Jonsson P, Bandlamudi C, Cheng ML, Srinivasan P, Chavan SS, Friedman ND, Rosen EY, Richards AL, Bouvier N, Selcuklu SD, Bielski CM, Abida W, Mandelker D, Birsoy O, Zhang L, Zehir A, Donoghue MTA, Baselga J, Offit K, Scher HI, O'Reilly EM, Stadler ZK, Schultz N, Socci ND, Viale A, Ladanyi M, Robson ME, Hyman DM, Berger MF, Solit DB, Taylor BS (2019), Tumour lineage shapes BRCA-mediated phenotypes. Nature 571, 7766, 576-579. https://doi.org/10.1038/s41586-019-1382-1.

12. Blokzijl F, de Ligt J, Jager M, Sasselli V, Roerink S, Sasaki N, Huch M, Boymans S, Kuijk E, Prins P, Nijman IJ, Martincorena I, Mokry M, Wiegerinck CL, Middendorp S, Sato T, Schwank G, Nieuwenhuis EE, Verstegen MM, van der Laan LJ, de Jonge J, IJzermans JN, Vries RG, van de Wetering M, Stratton MR, Clevers H, Cuppen E, van Boxtel R (2016), Tissue-specific mutation accumulation in human adult stem cells during life. Nature 538, 7624, 260-264. https://doi.org/10.1038/nature19768.

13. Guha M (2017), Misunderstanding the bad luck of getting cancer. J Natl Cancer Inst 109, 6, 2-3. https://doi.org/ $10.1093 /$ jnci/djx126.

14. Bennett WH (1899), Some peculiarities in the behavior of certain malignant and innocent growths. Lancet 1, 3-7.

15. Rosenman RH (1946), Spontaneous regression of metastatic sarcoma; report of case. Am J Clin Pathol 16, 281-289.

16. Penner DW (1953), Spontaneous regression of a case of myosarcoma. Cancer 6, 4, 776-779.

17. Sumner WC (1953), Spontaneous regression of melanoma. Cancer 6, 5, 1040-1043.

18. Levison VB (1955), Spontaneous regression of a malignant melanoma. Br Med J 1, 4911, 458-459. PMCID: PMC2061225.

19. Everton TC, Cole WH (1966), Spontaneous regression of cancer, W.B. Saunders, Philadelphia.
20. McKinnell R, Deggins B, Labat D (1969), Transplantation of pluripotential nuclei from triploid frog tumors. Science 165, 3891, 394-396. https://doi.org/10.1126/science.165.3891.394.

21. Rubin H (1980), Is somatic mutation the major mechanism of malignant transformation? J Natl Cancer Inst 64, 5, 995-1000. https://doi.org/10.1093/jnci/64.5.995.

22. Fairlamb DG (1981), Spontaneous regression of metastases of renal cancer: a report of two cases including the first recorded regression following irradiation of a dominant metastasis and review of the world literature. Cancer 47, 8, 2102-2106. PMID: 7226102.

23. Lust JM, Carlson DL, Kowles R, Rollins-Smith L, Williams JW 3rd, McKinnell RG (1991), Allografts of tumor nuclear transplantation embryos: differentiation competence. Proc Natl Acad Sci USA 88, 15, 6883-6887. https://doi.org/ 10.1073/pnas.88.15.6883.

24. Tang R, Changchien CR, Wu MC, Fan CW, Liu KW, Chen JS, Chien HT, Hsieh LL (2004), Colorectal cancer without high microsatellite instability and chromosomal instability an alternative genetic pathway to human colorectal cancer. Carcinogenesis 25, 5, 841-846. https://doi.org/10.1093/ carcin/bgh074.

25. Rosenfeld S (2013), Are the somatic mutation and tissue organization field theories of carcinogenesis incompatible? Cancer Inform 12, 221-229. https://doi.org/10.4137/CIN. S13013.

26. Wang RA, Li ZS, Zhang HZ, Zheng PJ, Li QL, Shi JG, Yan QG, Ye J, Wang JB, Guo Y, Huang XF, Yu YH (2013), Invasive cancers are not necessarily from preformed in situ tumours - an alternative way of carcinogenesis from misplaced stem cells. J Cell Mol Med 17, 7, 921-926. https://doi.org/10.1111/jcmm.12078.

27. Versteeg R (2014), Cancer: tumours outside the mutation box. Nature 506, 7489, 438-439. https://doi.org/ 10.1038 /nature13061.

28. Parker M, Mohankumar KM, Punchihewa C, Weinlich R, Dalton JD, Li Y, Lee R, Tatevossian RG, Phoenix TN, Thiruvenkatam R, White E, Tang B, Orisme W, Gupta K, Rusch M, Chen X, Li Y, Nagahawhatte P, Hedlund E, Finkelstein D, Wu G, Shurtleff S, Easton J, Boggs K, Yergeau D, Vadodaria B, Mulder HL, Becksfort J, Gupta P, Huether R, Ma J, Song G, Gajjar A, Merchant T, Boop F, Smith AA, Ding L, Lu C, Ochoa K, Zhao D, Fulton RS, Fulton LL, Mardis ER, Wilson RK, Downing JR, Green DR, Zhang J, Ellison DW, Gilbertson RJ (2014), C11orf95RELA fusions drive oncogenic NF- $\kappa$ B signalling in ependymoma. Nature 506, 7489, 451-455. https://doi.org/ 10.1038/nature13109. Erratum. In: Nature. 2014 Apr 24, 508(7497), 554. Becksford, Jared [corrected to Becksfort, Jared].

29. Adjiri A (2017), DNA mutations may not be the cause of cancer. Oncol Ther 5, 1, 85-101. https://doi.org/10.1007/ s40487-017-0047-1.

30. Cirillo N, Hassona Y, Celentano A, Lim KP, Manchella S, Parkinson EK, Prime SS (2017), Cancer-associated fibroblasts regulate keratinocyte cell-cell adhesion via TGF$\beta$-dependent pathways in genotype-specific oral cancer. Carcinogenesis 38, 1, 76-85. https://doi.org/10.1093/ carcin/bgw113.

31. Gatenby RA, Brown J (2017), Mutations, evolution and the central role of a self-defined fitness function in the initiation and progression of cancer. Biochim Biophys Acta 1867, 2, 162-166. https://doi.org/10.1016/j.bbcan.2017.03.005.

32. Liggett LA, DeGregori J (2017), Changing mutational and adaptive landscapes and the genesis of cancer. Biochim Biophys Acta 1867, 2, 84-94. https://doi.org/10.1016/j. bbcan.2017.01.005. 
33. Shindo K, Yu J, Suenaga M, Fesharakizadeh S, Cho C, Macgregor-Das A, Siddiqui A, Witmer PD, Tamura K, Song TJ, Navarro Almario JA, Brant A, Borges M, Ford M, Barkley T, He J, Weiss MJ, Wolfgang CL, Roberts NJ, Hruban RH, Klein AP, Goggins M (2017), Deleterious germline mutations in patients with apparently sporadic pancreatic adenocarcinoma. J Clin Oncol 35, 30, 3382-3390. https://doi.org/10.1200/JCO.2017.72.3502.

34. Tez M (2018), Pragmatic cancer approach time to change? 4open 1, 2, 1-2. https://doi.org/10.1051/fopen/2018002.

35. Tomasetti C, Vogelstein B (2015), Variation in cancer risk among tissues can be explained by the number of stem cell divisions. Science 347, 6217, 78-81. https://doi.org/ $10.1126 /$ science. 1260825 .

36. Tomasetti C, Vogelstein B (2017), On the slope of the regression between stem cell divisions and cancer risk, and the lack of correlation between stem cell divisions and environmental factors associated cancer risk. PLoS One 12, 5, e017-5535. https://doi.org/10.1371/journal.pone.0175535.

37. Belikov AV (2017), The number of key carcinogenic events can be predicted from cancer incidence. Sci Rep 7, 1, 12170. https://doi.org/10.1038/s41598-017-12448-7.

38. Beljaeva M (2017), Comment to "The number of key carcinogenic events can be predicted from cancer incidence" by Aleksey V. Belikov (updated). https://www.researchgate. net/publication/320290098_Comment_to_The_number_ of_key_carcinogenic_events_can_be_presicted_from cancer_-incidence_by__Aleksey_V_ Belikov.

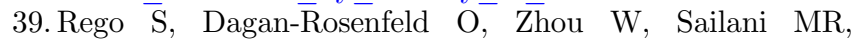
Limcaoco P, Colbert E, Avina M, Wheeler J, Craig C, Salin D, Rost H, Dunn J, McLaughlin T, Steinmetz LM, Bernstein JA, Snyder MP (2017), High frequency actionable pathogenic exome mutations in an average-risk cohort. bioRxiv, Jun 18. https://doi.org/10.1101/151225.

40. Sarbia M, Ott N, Pühringer-Oppermann F, Brücher BL (2007), The predictive value of molecular markers (p53, EGFR, ATM, CHK2) in multimodally treated squamous cell carcinoma of the oesophagus. Br J Cancer 97, 10, 1404-1408. https://doi.org/10.1038/sj.bjc.6604037.

41. Maréchal A, Zou L (2013), DNA damage sensing by the ATM and ATR kinases. Cold Spring Harb Perspect Biol 5, pii: a012716. https://doi.org/10.1101/cshperspect.a012716.

42. Perkins GL, Slater ED, Sanders GK, Prichard JG (2003), Serum tumor markers. Am Fam Physician 68, 6, 1075-1082. PMID: 14524394.

43. Lapthorn C, Pullen FS, Chowdhry BZ, Wright P, Perkins GL, Heredia Y (2015), How useful is molecular modelling in combination with ion mobility mass spectrometry for "small molecule" ion mobility collision cross-sections? Analyst 140, 20, 6814-6823. https://doi.org/10.1039/c5an00411j.

44. Ling S, Hu Z, Yang Z, Yang F, Li Y, Lin P, Chen K, Dong L, Cao L, Tao Y, Hao L, Chen Q, Gong Q, Wu D, Li W, Zhao W, Tian X, Hao C, Hungate EA, Catenacci DV, Hudson RR, Li WH, Lu X, Wu CI (2015), Extremely high genetic diversity in a single tumor points to prevalence of nonDarwinian cell evolution. Proc Natl Acad Sci USA 112, 47, E6496-6505. https://doi.org/10.1073/pnas.1519556112. Correction: DOI: https://doi.org/10.1073/pnas.1600151113.

45. Vu V, Verster AJ, Schertzberg M, Chuluunbaatar T, Spensley M, Pajkic D, Hart GT, Moffat J, Fraser AG (2015), Natural variation in gene expression modulates the severity of mutant phenotypes. Cell 162, 2, 391-402. https://doi.org/10.1016/j.cell.2015.06.037.

46. Yokoyama A, Kakiuchi N, Yoshizato T, Nannya Y, Suzuki H, Takeuchi Y, Shiozawa Y, Sato Y, Aoki K, Kim
SK, Fujii Y, Yoshida K, Kataoka K, Nakagawa MM, Inoue Y, Hirano T, Shiraishi Y, Chiba K, Tanaka H, Sanada M, Nishikawa Y, Amanuma Y, Ohashi S, Aoyama I, Horimatsu T, Miyamoto S, Tsunoda S, Sakai Y, Narahara M, Brown JB, Sato Y, Sawada G, Mimori K, Minamiguchi S, Haga H, Seno H, Miyano S, Makishima H, Muto M, Ogawa S (2019), Age-related remodelling of oesophageal epithelia by mutated cancer drivers. Nature 565, 7739, 312-317. https://doi.org/10.1038/s41586-018-0811-x.

47. Itzhaki RF, Lathe R (2018), Herpes viruses and senile dementia: first population evidence for a causal link. J Alzheimers Dis 64, 2, 363-366. https://doi.org/10.3233/ JAD-180266.

48. Fülöp T, Itzhaki RF, Balin BJ, Miklossy J, Barron AE (2018), Role of microbes in the development of Alzheimer's disease: state of the art - An International Symposium Presented at the 2017 IAGG Congress in San Francisco. Front Genet 9, 362. https://doi.org/10.3389/fgene.2018.00362.

49. Cacace R, Sleegers K, Van Broeckhoven C (2016), Molecular genetics of early-onset Alzheimer's disease revisited. Alzheimers Dement 12, 6, 733-748. https://doi.org/ 10.1016/j.jalz.2016.01.012.

50. Conolly RB, Lutz WK (2004), Nonmonotonic dose-response relationships: mechanistic basis, kinetic modeling, and implications for risk assessment. Toxicol Sci 77, 1, 151157. https://doi.org/10.1093/toxsci/kfh007.

51. LaFond RE (1978), Cancer - The Outlaw Cell, American Chemical Society, Washington, DC.

52. Cleaver JE (1986), DNA repair and replication in xeroderma pigmentosum and related disorders. Basic Life Sci 39, 425-438. PMID: 3767846.

53. Milota M, Jones DL, Cleaver J, Jamall JS (2011), Xeroderma pigmentosum family support group: helping families and promoting clinical initiatives. DNA Repair (Amst) 10, 7, 792-797. https://doi.org/10.1016/j.dnarep.2011.04.027.

54. Herman JG (1999), Hypermethylation of tumor suppressor genes in cancer. Semin Cancer Biol 9, 5, 359-367. https://doi.org/10.1006/scbi.1999.0138.

55. Sharma S, Kelly TK, Jones PA (2010), Epigenetics in cancer. Carcinogenesis 31, 1, 27-36. https://doi.org/ $10.1093 /$ carcin/bgp220.

56. Nakajima T, Maekita T, Oda I, Gotoda T, Yamamoto S, Umemura S, Ichinose M, Sugimura T, Ushijima T, Saito D (2006), Higher methylation levels in gastric mucosae significantly correlate with higher risk of gastric cancers. Cancer Epidemiol Biomarkers Prev 15, 11, 2317-2321. https://doi. org/10.1158/1055-9965.EPI-06-0436.

57. Zhang BG, Hu L, Zang MD, Wang HX, Zhao W, Li JF, Su LP, Shao Z, Zhao X, Zhu ZG, Yan M, Liu B (2016), Helicobacter pylori CagA induces tumor suppressor gene hypermethylation by upregulating DNMT1 via AKT-NF $\kappa \mathrm{B}$ pathway in gastric cancer development. Oncotarget 7, 9, 9788-9800. https://doi.org/10.18632/oncotarget.7125.

58. Kondo T, Oka T, Sato H, Shinnou Y, Washio K, Takano M, Morito T, Takata K, Ohara N, Ouchida M, Shimizu K, Yoshino T (2009), Accumulation of aberrant CpG hypermethylation by Helicobacter pylori infection promotes development and progression of gastric MALT lymphoma. Int J Oncol 35, 3, 547-557. https://doi.org/10.3892/ ijo_00000366.

59. Moon DC, Choi CH, Lee SM, Lee JH, Kim SI, Kim DS, Lee JC (2012), Nuclear translocation of Acinetobacter baumannii transposase induces DNA methylation of $\mathrm{CpG}$ regions in the promoters of E-cadherin gene. PLoS One 7, 6, e38974. https://doi.org/10.1371/journal.pone.0038974. 
60. Zhong X, Isharwal S, Naples JM, Shiff C, Veltri RW, Shao C, Bosompem KM, Sidransky D, Hoque MO (2013), Hypermethylation of genes detected in urine from Ghanaian adults with bladder pathology associated with Schistosoma haematobium infection. PLoS One 8, 3, e59089. https://doi. org/10.1371/journal.pone.0059089.

61. Lee SM, Lee YG, Bae JB, Choi JK, Tayama C, Hata K, Yun Y, Seong JK, Kim YJ (2014), HBx induces hypomethylation of distal intragenic $\mathrm{CpG}$ islands required for active expression of developmental regulators. Proc Natl Acad Sci USA 111, 26, 9555-9560. https://doi.org/10.1073/pnas. 1400604111 .

62. Matsusaka K, Funata S, Fukuyo M, Seto Y, Aburatani H, Fukayama M, Kaneda A (2017), Epstein-Barr virus infection induces genome-wide de novo DNA methylation in non-neoplastic gastric epithelial cells. J Pathol 242, 4, 391-399. https://doi.org/10.1002/path.4909.

63. Yeung CL, Tsang TY, Yau PL, Kwok TT (2017), Human papillomavirus type 16 E6 suppresses microRNA-23b expression in human cervical cancer cells through DNA methylation of the host gene C9orf3. Oncotarget 8, 7, 12158-12173. https://doi.org/10.18632/oncotarget.14555.

64. Frigola J, Solé X, Paz MF, Moreno V, Esteller M, Capellà G, Peinado MA (2005), Differential DNA hypermethylation and hypomethylation signatures in colorectal cancer. Hum Mol Genet 14, 2, 319-326. https://doi.org/10.1093/hmg/ ddi028.

65. Hur K, Niwa T, Toyoda T, Tsukamoto T, Tatematsu M, Yang HK, Ushijima T (2011), Insufficient role of cell proliferation in aberrant DNA methylation induction and involvement of specific types of inflammation. Carcinogenesis 32, 1, 35-41. https://doi.org/10.1093/carcin/bgq219.

66. Na HK, Woo JH (2014), Helicobacter pylori induces hypermethylation of $\mathrm{CpG}$ Islands through upregulation of DNA methyltransferase: possible involvement of reactive oxygen/nitrogen species. J Cancer Prev 19, 4, 259-264. https://doi.org/10.15430/JCP.2014.19.4.259.

67. Maiuri AR, Li H, Stein BD, Tennessen JM, O'Hagan HM (2018), Inflammation-induced DNA methylation of DNA polymerase gamma alters the metabolic profile of colon tumors. Cancer Metab 6, 9. https://doi.org/10.1186/ s40170-018-0182-7.

68. Brücher BLDM, Roder JD, Fink U, Stein HJ, Busch R, Siewert JR (1998), Prognostic factors in resected primary small bowel tumors. Dig Surg 15, 1, 42-51. https://doi.org/ $10.1159 / 000018585$.

69. Brücher BLDM, Roder JD, Busch R, Fink U, Stein HJ, Werner M, Siewert JR (2001), New aspects in prognostic factors in adenocarcinomas of the small bowel. Hepatogastroenterology 48, 39, 727-732PMID: 11462914.

70. Brücher BLDM (2006), Maligne Dünndarmtumoren, in: JR Siewert, M Rothmund, V Schumpelick (Eds.), Praxis der Viszeralchirurgie, 2nd edn. Springer-Verlag, Berlin, pp. 611-620.

71. Brücher BLDM, Geddert H, Langner C, Höfler H, Fink U, Siewert JR, Sarbia M (2006), Hypermethylation of hMLH1, HPP1, p14ARF, p16INK4A, and APC in primary adenocarcinomas of the small bowel. Int J Cancer 119, 6, 1298-1302. https://doi.org/10.1002/ijc.21990.

72. Bernstein C, Bernstein H (2015), Epigenetic reduction of DNA repair in progression to gastrointestinal cancer. World J Gastrointest Oncol 7, 5, 30-46. https://doi.org/10.4251/ wjgo.v7.i5.30.

73. Herbst A, Vdovin N, Gacesa S, Philipp A, Nagel D, Holdt LM, Op den Winkel M, Heinemann V, Stieber P, Graeven U, Reinacher-Schick A, Arnold D, Ricard I, Mansmann U, Hegewisch-Becker S, Kolligs FT (2017),
Methylated free-circulating HPP1 DNA is an early response marker in patients with metastatic colorectal cancer. Int J Cancer 140, 9, 2134-2144. https://doi.org/10.1002/ijc.30625.

74. Ptashne M (2013), Epigenetics: core misconcept. Proc Natl Acad Sci USA 110, 18, 7101-7103. https://doi.org/10.1073/ pnas.1305399110.

75. Shapiro JA (2011), Evolution: a view from the 21st century, FT Press Science, Upper Saddle River, NJ.

76. Li K, Hong W, Jiao H, Wang GD, Rodriguez KA, Buffenstein R, Zhao Y, Nevo E, Zhao H (2015), Sympatric speciation revealed by genome-wide divergence in the blind mole rat Spalax. Proc Natl Acad Sci USA 112, 38, 1190511910. https://doi.org/10.1073/pnas.1514896112.

77. Chi N, Epstein JA (2002), Getting your Pax straight: Pax proteins in development and disease. Trends Genet 18, 1, 41-47. PMID: 11750700.

78. Blake JA, Ziman MR (2014), Pax genes: regulators of lineage specification and progenitor cell maintenance. Development 141, 4, 737-751. https://doi.org/10.1242/ dev.091785.

79. Navet S, Buresi A, Baratte S, Andouche A, BonnaudPonticelli L, Bassaglia Y (2017), The Pax gene family: highlights from cephalopods. PLoS One 12, 3, e0172719. https://doi.org/10.1371/journal.pone.0172719.

80. Schedl P, Artavanis-Tsakonas S, Steward R, Gehring WJ, Mirault ME, Goldschmidt-Clermont M, Moran L, Tissières A (1978), Two hybrid plasmids with D. melanogaster DNA sequences complementary to mRNA coding for the major heat shock protein. Cell 14, 4, 921-929. https://doi.org/ 10.1016/0092-8674(78)90346-x.

81. Garber RL, Kuroiwa A, Gehring WJ (1983), Genomic and cDNA clones of the homeotic locus Antennapedia in Drosophila. EMBO J 2, 11, 2027-2036. PMCID: PMC555405.

82. McGinnis W, Levine MS, Hafen E, Kuroiwa A, Gehring WJ (1984), A conserved DNA sequence in homoeotic genes of the Drosophila Antennapedia and bithorax complexes. Nature 308, 5958, 428-433. https://doi.org/10.1038/308428a0.

83. Affolter M, Wüthrich K (2014), Walter Jakob Gehring: a master of developmental biology. Proc Natl Acad Sci USA 111, 35, 12574-12575. https://doi.org/10.1073/pnas. 1413434111.

84. Quiring R, Walldorf U, Kloter U, Gehring WJ (1994), Homology of the eyeless gene of Drosophila to the small eye gene in mice and Aniridia in humans. Science 265, 5173, 785-789. https://doi.org/10.1126/science.7914031.

85. Halder G, Callaerts P, Gehring WJ (1995), Induction of ectopic eyes by targeted expression of the eyeless gene in Drosophila. Science 267, 5205, 1788-1792.

86. Walther C, Gruss P (1991), Pax-6, a murine paired box gene, is expressed in the developing CNS. Development 113, 4, 1435-1449. PMID: 1687460.

87. Gruss P, Walther C (1992), Pax in development. Cell 69, 5, 719-722. https://doi.org/10.1016/0092-8674(92)90281-g.

88. Richardson J, Cvekl A, Wistow G (1995), Pax-6 is essential for lens-specific expression of zeta-crystallin. Proc Natl Acad Sci USA 92, 10, 4676-4680. https://doi.org/10.1073/ pnas.92.10.4676.

89. Dahl E, Koseki H, Balling R (1997), Pax genes and organogenesis. Bioessays 19, 9, 755-765. https://doi.org/ 10.1002/bies.950190905.

90. Ramaesh T, Ramaesh K, Leask R, Springbett A, Riley SC, Dhillon B, West JD (2006), Increased apoptosis and abnormal wound-healing responses in the heterozygous Pax6+/- mouse cornea. Invest Ophthalmol Vis Sci 47, 5, 1911-1917. https://doi.org/10.1167/iovs.05-1028. 
91. Xia X, Yin W, Zhang X, Yu X, Wang C, Xu S, Feng W, Yang H (2015), PAX6 overexpression is associated with the poor prognosis of invasive ductal breast cancer. Oncol Lett 10, 3, 1501-1506. https://doi.org/10.3892/ol. 2015.3434.

92. Hellwinkel OJ, Kedia M, Isbarn H, Budäus L, Friedrich MG (2008), Methylation of the TPEF- and PAX6-promoters is increased in early bladder cancer and in normal mucosa adjacent to pT1a tumours. BJU Int 101, 6, 753-757. https://doi.org/10.1111/j.1464-410X.2007.07322.x.

93. Shyr CR, Tsai MY, Yeh S, Kang HY, Chang YC, Wong PL, Huang CC, Huang KE, Chang C (2010), Tumor suppressor PAX6 functions as androgen receptor co-repressor to inhibit prostate cancer growth. Prostate 70, 2, 190-199. https://doi. org $/ 10.1002 /$ pros. 21052 .

94. Muratovska A, Zhou C, He S, Goodyer P, Eccles MR (2003), Paired-Box genes are frequently expressed in cancer and often required for cancer cell survival. Oncogene 22, 39, 7989-7997. https://doi.org/10.1038/sj.onc.1206766.

95. Moelans CB, Verschuur-Maes AH, van Diest PJ (2011), Frequent promoter hypermethylation of BRCA2, CDH13, MSH6, PAX5, PAX6 and WT1 in ductal carcinoma in situ and invasive breast cancer. J Pathol 225, 2, 222-231. https://doi.org/10.1002/path.2930.

96. Zong X, Yang H, Yu Y, Zou D, Ling Z, He X, Meng X (2011), Possible role of Pax-6 in promoting breast cancer cell proliferation and tumorigenesis. BMB Rep 44, 9, 595-600. https://doi.org/10.5483/bmbrep.2011. 44.9.595.

97. Urrutia G, Laurito S, Campoy E, Nasif D, Branham MT, Roqué M (2018), PAX6 promoter methylation correlates with MDA-MB-231 cell migration, and expression of MMP2 and MMP9. Asian Pac J Cancer Prev 19, 10, 2859-2866. https://doi.org/10.22034/APJCP.2018.19.10.2859.

98. Yamashita S, Tsujino Y, Moriguchi K, Tatematsu M, Ushijima T (2006), Chemical genomic screening for methylation-silenced genes in gastric cancer cell lines using 5-aza2'-deoxycytidine treatment and oligonucleotide microarray. Cancer Sci 97, 1, 64-71. https://doi.org/10.1111/j.13497006.2006.00136.x.

99. Yang Q, Shao Y, Shi J, Qu Y, Wu K, Dang S, Shi B, Hou P (2014), Concomitant PIK3CA amplification and RASSF1A or PAX6 hypermethylation predict worse survival in gastric cancer. Clin Biochem 47, 1-2, 111-116. PMID: 24505629.

100. Liu RZ, Monckton EA, Godbout R (2012), Regulation of the FABP7 gene by PAX6 in malignant glioma cells. Biochem Biophys Res Commun 422, 3, 482-487. https://doi.org/10.1016/j.bbrc.2012.05.019.

101. Toyota M, Ho C, Ahuja N, Jair KW, Li Q, Ohe-Toyota M, Baylin SB, Issa JP (1999), Identification of differentially methylated sequences in colorectal cancer by methylated CpG island amplification. Cancer Res 59, 10, 2307-2312. PMID: 10344734.

102. Shih YL, Kuo CC, Yan MD, Lin YW, Hsieh CB, Hsieh TY (2016), Quantitative methylation analysis reveals distinct association between PAX6 methylation and clinical characteristics with different viral infections in hepatocellular carcinoma. Clin Epigenetics 8, 41. https://doi.org/10.1186/ s13148-016-0208-3.

103. Feng Q, Stern JE, Hawes SE, Lu H, Jiang M, Kiviat NB (2010), DNA methylation changes in normal liver tissues and hepatocellular carcinoma with different viral infection. Exp Mol Pathol 88, 2, 287-292. https://doi.org/10.1016/j. yexmp.2010.01.002.

104. Swisshelm K, Disteche CM, Thorvaldsen J, Nelson A, Salk D (1990), Age-related increase in methylation of ribosomal genes and inactivation of chromosome-specific rRNA gene clusters in mouse. Mutat Res 237, 3-4, 131-146. https://doi.org/10.1016/0921-8734(90)90019-n.

105. Liang G, Salem CE, Yu MC, Nguyen HD, Gonzales FA, Nguyen TT, Nichols PW, Jones PA (1998), DNA methylation differences associated with tumor tissues identified by genome scanning analysis. Genomics 53, 3, 260-268. https://doi.org/10.1006/geno.1998.5502.

106. Zhang X, Yang X, Wang J, Liang T, Gu Y, Yang D (2015), Down-regulation of PAX6 by promoter methylation is associated with poor prognosis in non-small cell lung cancer. Int J Clin Exp Pathol 8, 9, 11452-11457. PMCID: PMC4637690.

107. Shubham K, Mishra R (2012), Pax6 interacts with SPARC and TGF- $\beta$ in murine eyes. Mol Vis 18, 951-956. PMCID: PMC3335779.

108. Engler AJ, Sen S, Sweeney HL, Discher DE (2006), Matrix elasticity directs stem cell lineage specification. Cell 126, 4, 677-689. https://doi.org/10.1016/j.cell.2006.06.044.

109. Mani SA, Guo W, Liao MJ, Eaton EN, Ayyanan A, Zhou AY, Brooks M, Reinhard F, Zhang CC, Shipitsin M, Campbell LL, Polyak K, Brisken C, Yang J, Weinberg RA (2008), The epithelial-mesenchymal transition generates cells with properties of stem cells. Cell 133, 4, 704-715. https://doi.org/10.1016/j.cell.2008.03.027.

110. Morel AP, Lievre M, Thomas C, Hinkal G, Ansieau S, Puisieux A (2008), Generation of breast cancer stem cells through epithelial-mesenchymal transition. PLoS One 3, 8, e2888. https://doi.org/10.1371/journal.pone.0002888.

111. Brücher BLDM, Jamall JS (2019), Transition from normal to cancerous cell by precancerous niche (PCN) induced chronic cell-matrix stress. 4open 2, 14, 1-31. https://doi. org $/ 10.1051 /$ fopen $/ 2018996$.

112. Wogan GN, Hecht SS, Felton JS, Conney AH, Loeb LA (2004), Environmental and chemical carcinogenesis. Semin Cancer Biol 14, 6, 473-486. https://doi.org/10.1016/j. semcancer.2004.06.010.

113. Brücher BLDM, Jamall JS (2019), Prelude and premise to the special issue: disruption of homeostasis-induced signaling and crosstalk in the carcinogenesis paradigm "Epistemology of the origin of cancer". 4open 2, 6, 1-8. https://doi. org $/ 10.1051 /$ fopen $/ 2019005$.

114. Warburg O (1923), Versuche an überlebendem CarcinomGewebe (Methoden). Biochem Zeitschr 142, 317-333.

115. Warburg O, Posener K, Negelein E (1924), Über den Stoffwechsel der Carcinomzelle. Biochem Zeitschr 152, 309-344.

116. Cori CA, Cori GT (1925), The carbohydrate metabolism of tumours I: The free sugar, lactic acid, and glycogen content of malignant tumors. J Biol Chem 64, 11-22.

117. Cori CA, Cori GT (1925), The carbohydrate metabolism of tumours II: The changes in the suga, latic acid, and cocombining power of blood passing through a tumor. J Biol Chem 65, 397-405.

118. Warburg O (1925), Über den Stoffwechsel der Carcinomzelle. Klin Wochenschr 4, 534-536.

119. Seguin A, Lavoisier AL (1789), Premier memoire sur la respiration des animaux. Mem Acad R Sci 185, 31-51.

120. Seguin A, Lavoisier AL (1790), Premier memoire sur la transpiration des animaux. Mem Acad R Sci 601.

121. Seguin A, Lavoisier AL (1814), Second memoire sur la respiration. Ann Chim 9I, 518.

122. Seguin A, Lavoisier AL (1814), Second memoire sur la transpiration des animaux. Ann Chim 90, 5.

123. Underwood EA (1944), Lavoisier and the history of respiration. Proc $\mathrm{R}$ Soc Med 37, 6, 247-262. PMCID: PMC2180993. 
124. Gilbert DL (2002), From the breath of life to reactive oxygen species, in DL Gilbert, CA Colton (Eds.), Reactive Oxygen Species in Biological Systems. Springer, Boston, MA, USA, ISBN 978-0-306-45756-2, pp. 3-31.

125. Karamanou M, Tsoucalas G, Androutsos G (2013), Hallmarks in the study of respiratory physiology and the crucial role of Antoine-Laurent de Lavoisier (1743-1794). Am J Physiol Lung Cell Mol Physiol 305, 9, L591-594. https://doi.org/10.1152/ajplung.00142.2013.

126. Rubner M (1883), Ueber den Einfluss der Körpergrösse auf Stoff- und Kraftwechsel. Zeitschrift fur Biologie 19, 536-562.

127. Rubner M (1885), Calorimetrische Untersuchungen I. Z Biol $21,250-334$.

128. Rubner M (1885), Calorimetrische Untersuchungen II. Z Biol 21, 337-410.

129. Rubner M (1902), Gesetze des Energieverbrauchs bei der Ernährung, F. Deuticke, Leipzig \& Wien.

130. Rubner M (1908), Das Wachstumsproblem und die Lebensdauer des Menschen und einiger Saugetiere vom energetischen Standpunkt aus betrachtet. Arch Hyg 66, 153.

131. Rubner M (1908), Problem der Lebensdauer und seine Beziehungen zu Wachstum und zu Ernährung, R. Oldenbourg, München und Berlin.

132. Rubner M (1908), Volksernährungsfragen, Akademische Verlagsgesellschaft, Leipzig, IV, pp. 1-143.

133. White CR, Seymour RS (2005), Allometric scaling of mammalian metabolism. J Exp Biol 208, Pt 9, 1611-1619.

134. Withers PC, Cooper CE, Maloney SK, Bozinovic F, Cruz Neto AP (2016), Ecological and environmental physiology of mammals, Oxford University Press, Oxford and New York. Print ISBN - 13: 9780199642717. https://doi.org/ 10.1093/acprof:oso/9780199642717.001.0001.

135. Martin HG, Loevenhart AS, Bunting CH (1918), The morphological changes in the tissues of the rabbit as a result of reduced oxidation. J Exp Med 27, 3, 399-412. https://doi.org/10.1084/jem.27.3.399.

136. Dallwig HC, Kolls AC, Loevenhart AS (1915), The mechanism adapting the oxygen capacity of the blood to the requirements of the tissues. Am J Physiol 39, 77-108.

137. Appleby PN, Crowe FL, Bradbury KE, Travis RC, Key TJ (2016), Mortality in vegetarians and comparable nonvegetarians in the United Kingdom. Am J Clin Nutr 103, 1, 218-230. https://doi.org/10.3945/ajcn.115.119461.

138. Penniecook-Sawyers JA, Jaceldo-Siegl K, Fan J, Beeson L, Knutsen S, Herring P, Fraser GE (2016), Vegetarian dietary patterns and the risk of breast cancer in a low-risk population. Br J Nutr 115, 10, 1790-1797. https://doi. org $/ 10.1017 /$ S0007114516000751.

139. Gathani T, Barnes I, Ali R, Arumugham R, Chacko R, Digumarti R, Jivarajani P, Kannan R, Loknatha D, Malhotra H, Mathew BS, INDOX Cancer Research Network Collaborators (2017), Lifelong vegetarianism and breast cancer risk: a large multicentre case control study in India. BMC Womens Health 17, 1, 6. https://doi.org/ 10.1186/s12905-016-0357-8.

140. Key TJ, Appleby PN, Crowe FL, Bradbury KE, Schmidt JA, Travis RC (2014), Cancer in British vegetarians: updated analyses of 4998 incident cancers in a cohort of 32,491 meat eaters, 8612 fish eaters, 18,298 vegetarians, and 2246 vegans. Am J Clin Nutr 100, Suppl 1, 378S-385S. https://doi.org/10.3945/ajcn.113.071266.

141. Orlich MJ, Singh PN, Sabaté J, Fan J, Sveen L, Bennett H, Knutsen SF, Beeson WL, Jaceldo-Siegl K, Butler TL, Herring RP, Fraser GE (2015), Vegetarian dietary patterns and the risk of colorectal cancers. JAMA Intern Med 175, 5, 767-776. https://doi.org/10.1001/jamainternmed. 2015.59 .
142. Nery R (1986), Cancer: An enigma in biology and society, Croom Helm, London, UK. ISBN 0709918259.

143. Basree MM, Shinde N, Koivisto C, Cuitino M, Kladney R, Zhang J, Stephens J, Palettas M, Zhang A, Kim HK, AceroBedoya S, Trimboli A, Stover DG, Ludwig T, Ganju R, Weng D, Shields P, Freudenheim J, Leone GW, Sizemore GM, Majumder S, Ramaswamy B (2019), Abrupt involution induces inflammation, estrogenic signaling, and hyperplasia linking lack of breastfeeding with increased risk of breast cancer. Breast Cancer Res 21, 1, 80. https://doi.org/ 10.1186/s13058-019-1163-7.

144. Brücher BLDM, Jamall JS (2019), Undervalued ubiquitous proteins. 4open 2, 7, 1-13. https://doi.org/10.1051/fopen/ 2019002.

145. Brücher BLDM, Jamall JS (2019), Chronic inflammation evoked by pathogenic stimulus during carcinogenesis. 4open 2, 8, 1-22. https://doi.org/10.1051/fopen/2018006.

146. Brücher BLDM, Jamall JS (2019), Precancerous niche $(\mathrm{PCN})$, a product of fibrosis with remodeling by incessant chronic inflammation. 4open 2, 11, 1-21. https://doi.org/ 10.1051/fopen/2018009.

147. Brücher BLDM, Jamall JS (2019), Microbiome and morbid obesity increase pathogenic stimulus diversity. 4open 2, 10 , 1-16. https://doi.org/10.1051/fopen/2018007.

148. Brücher BLDM, Jamall JS (2019), Metformin alters signaling homeostasis. 4open 2, 12, 1-17. https://doi.org/ $10.1051 /$ fopen $/ 2019006$.

149. Brücher BLDM, Jamall IS (2019), Eicosanoids in carcinogenesis. 4open 2, 9, 1-34. https://doi.org/10.1051/fopen/ 2018008.

150. Brücher BLDM, Lang F, Jamall JS (2019), NF- $\kappa$ B signaling and crosstalk in carcinogenesis. 4open 2, 13, 1-35. https://doi.org/10.1051/fopen/2019010.

151. Iqbal J, Al-Rashed J, Kehinde EO (2016), Detection of Trichomonas vaginalis in prostate tissue and serostatus in patients with asymptomatic benign prostatic hyperplasia. BMC Infect Dis 16, 1, 506. https://doi.org/10.1186/s12879016-1843-1.

152. Kim SS, Kim JH, Han IH, Ahn MH, Ryu JS (2016), Inflammatory responses in a benign prostatic hyperplasia epithelial cell line (BPH-1) infected with Trichomonas vaginalis. Korean J Parasitol 54, 2, 123-132. https://doi. org/10.3347/kjp.2016.54.2.123.

153. Jang KS, Han IH, Lee SJ, Yoo J, Kim YS, Sim S, Ryu JS (2019), Experimental rat prostatitis caused by Trichomonas vaginalis infection. Prostate 79, 4, 379-389. https://doi. org $/ 10.1002 / \operatorname{pros} .23744$.

154. Kim JH, Han IH, Kim SS, Park SJ, Min DY, Ahn MH, Ryu JS (2017), Interaction between Trichomonas vaginalis and the Prostate Epithelium. Korean J Parasitol 55, 2, 213-218. https://doi.org/10.3347/kjp.2017.55.2.213.

155. Kim JH, Kim SS, Han IH, Sim S, Ahn MH, Ryu JS (2016), Proliferation of prostate stromal cell induced by benign prostatic hyperplasia epithelial cell stimulated with Trichomonas vaginalis via crosstalk with mast cell. Prostate 76, 15, 1431-1444. https://doi.org/10.1002/pros.23227.

156. Han IH, Kim JH, Jang KS, Ryu JS (2019), Inflammatory mediators of prostate epithelial cells stimulated with Trichomonas vaginalis promote proliferative and invasive properties of prostate cancer cells. Prostate 79, 10, 11331146. https://doi.org/10.1002/pros.23826.

157. Kitamura J, Uemura M, Kurozumi M, Sonobe M, Manabe T, Hiai H, Date H, Kinoshita K (2015), Chronic lung injury by constitutive expression of activation-induced cytidine deaminase leads to focal mucous cell metaplasia and cancer. PLoS One 10, 2, e0117986. https://doi.org/10.1371/journal. pone.0117986. Erratum (2015) PLoS One 10, 8, e0136807. 
158. Briso EM, Guinea-Viniegra J, Bakiri L, Rogon Z, Petzelbauer P, Eils R, Wolf R, Rincón M, Angel P, Wagner EF (2013), Inflammation-mediated skin tumorigenesis induced by epidermal c-Fos. Genes Dev 27, 18, 1959-1973. https://doi.org/10.1101/gad.223339.113.

159. Dueholm M, Hjorth IMD, Dahl K, Pedersen LK, Ørtoft G (2019), Identification of endometrial cancers and atypical hyperplasia: development and validation of a simplified system for ultrasound scoring of endometrial pattern. Maturitas 123, 15-24. https://doi.org/10.1016/j.maturitas.2019. 01.017.

160. Xiaoqun D, Xiaoli L, Jun L, Yang X (2019), The correlation between infections by human papillomavirus types $6 / 11$ and 16/18 and mammary gland hyperplasia with glandular thickening. Cell Mol Biol (Noisy-le-grand) 65, 5, 49-53. PMID: 31304906.

161. Honn KV, Grossi IM, Fitzgerald LA, Umbarger LA, Diglio CA, Taylor JD (1988), Lipoxygenase products regulate IRGpIIb/IIIa receptor mediated adhesion of tumor cells to endothelial cells, subendothelial matrix and fibronectin. Proc Soc Exp Biol Med 189, 1, 130-135. https://doi.org/ 10.3181/00379727-189-1-rc1.

162. Kim HP, Lee MS, Yu J, Park JA, Jong HS, Kim TY, Lee JW, Bang YJ (2004), TGF-beta1 (transforming growth factor-beta1)-mediated adhesion of gastric carcinoma cells involves a decrease in Ras/ERKs (extracellular-signalregulated kinases) cascade activity dependent on c-Src activity. Biochem J 379, Pt 1, 141-150. https://doi.org/ 10.1042/BJ20031408.

163. Sundquist E, Kauppila JH, Veijola J, Mroueh R, Lehenkari P, Laitinen S, Risteli J, Soini Y, Kosma VM, SawazakiCalone I, Macedo CC, Bloigu R, Coletta RD, Salo T (2017), Tenascin-C and fibronectin expression divide early stage tongue cancer into low- and high-risk groups. Br J Cancer 116, 5, 640-648. https://doi.org/10.1038/ bjc.2016.455.

164. D'Ardenne AJ, Burns J, Sykes BC, Bennett MK (1983), Fibronectin and type III collagen in epithelial neoplasms of gastrointestinal tract and salivary gland. J Clin Pathol 36, 7, 756-763. https://doi.org/10.1136/jcp.36.7.756.

165. Qin S, Zhang B, Xiao G, Sun X, Li G, Huang G, Gao X, Li X, Wang H, Yang C, Ren H (2016), Fibronectin protects lung cancer cells against docetaxel-induced apoptosis by promoting Src and caspase- 8 phosphorylation. Tumour Biol 37, 10, 13509-13520. https://doi.org/10.1007/s13277-0165206-8.

166. Yousif NG (2014), Fibronectin promotes migration and invasion of ovarian cancer cells through up-regulation of FAK-PI3K/Akt pathway. Cell Biol Int 38, 1, 85-91. https://doi.org/10.1002/cbin.10184.

167. Mahmud H, Kasai T, Khayrani AC, Asakura M, Oo AKK, Du J, Vaidyanath A, El-Ghlban S, Mizutani A, Seno A, Murakami H, Masuda J, Seno M (2018), Targeting glioblastoma cells expressing CD44 with liposomes encapsulating doxorubicin and displaying chlorotoxin-IgG Fc fusion protein. Int J Mol Sci 19, 3, Pii: E659. https://doi. org/10.3390/ijms19030659.

168. McFarlane S, McFarlane C, Montgomery N, Hill A, Waugh DJ (2015), CD44-mediated activation of $\alpha 5 \beta 1$-integrin, cortactin and paxillin signaling underpins adhesion of basal-like breast cancer cells to endothelium and fibronectin-enriched matrices. Oncotarget 6, 34, 36762-36773. https://doi.org/10.18632/oncotarget.5461.

169. Han Z, Lu ZR (2017), Targeting fibronectin for cancer imaging and therapy. J Mater Chem B 5, 4, 639-654. https://doi.org/10.1039/C6TB02008A.
170. Wang D, Gao CQ, Chen RQ, Jin CL, Li HC, Yan HC, Wang XQ (2016), Focal adhesion kinase and paxillin promote migration and adhesion to fibronectin by swine skeletal muscle satellite cells. Oncotarget 7, 21, 30845-30854. https://doi.org/10.18632/oncotarget. 9010.

171. Mackinnon AC, Tretiakova M, Henderson L, Mehta RG, Yan BC, Joseph L, Krausz T, Husain AN, Reid ME, Salgia R (2011), Paxillin expression and amplification in early lung lesions of high-risk patients, lung adenocarcinoma and metastatic disease. J Clin Pathol 64, 1, 16-24. https://doi. org/10.1136/jcp.2010.075853.

172. Kanteti R, Batra SK, Lennon FE, Salgia R (2016), FAK and paxillin, two potential targets in pancreatic cancer. Oncotarget 7, 21, 31586-31601. https://doi.org/10.18632/ oncotarget.8040.

173. Callaerts P, Halder G, Gehring WJ (1997), PAX-6 in development and evolution. Annu Rev Neurosci 20, 483-532. https://doi.org/10.1146/annurev.neuro.20.1.483.

174. Liu F, Wang L, Fu JL, Xiao Y, Gong X, Liu Y, Nie Q, Xiang JW, Yang L, Chen Z, Liu Y, Li DW (2018), Analysis of non-sumoylated and sumoylated isoforms of Pax-6, the master regulator for eye and brain development in ocular cell lines. Curr Mol Med 18, 8, 566-573. https://doi.org/ $10.2174 / 1566524019666190111153310$.

175. Baer K, Eriksson PS, Faull RL, Rees MI, Curtis MA (2007), Sox-2 is expressed by glial and progenitor cells and Pax- 6 is expressed by neuroblasts in the human subventricular zone. Exp Neurol 204, 2, 828-831. https://doi.org/10.1016/ j.expneurol.2006.12.008.

176. Moos M, Tacke R, Scherer H, Teplow D, Früh K, Schachner M (1988), Neural adhesion molecule L1 as a member of the immunoglobulin superfamily with binding domains similar to fibronectin. Nature 334, 6184, 701-703. https://doi.org/ 10.1038/334701a0.

177. Meech R, Kallunki P, Edelman GM, Jones FS (1999), A binding site for homeodomain and Pax proteins is necessary for L1 cell adhesion molecule gene expression by Pax- 6 and bone morphogenetic proteins. Proc Natl Acad Sci USA 96, 5, 2420-2425. https://doi.org/10.1073/pnas.96.5. 2420 .

178. Wu DM, Zhang T, Liu YB, Deng SH, Han R, Liu T, Li J, $\mathrm{Xu}$ Y (2019), The PAX6-ZEB2 axis promotes metastasis and cisplatin resistance in non-small cell lung cancer through PI3K/AKT signaling. Cell Death Dis 10, 5, 349. https://doi.org/10.1038/s41419-019-1591-4.

179. Little EC, Kubic JD, Salgia R, Grippo PJ, Lang D (2017), Canonical and alternative transcript expression of PAX6 and CXCR4 in pancreatic cancer. Oncol Lett 13, 6, 40274034. https://doi.org/10.3892/ol.2017.5956.

180. Esparza-López J, Alvarado-Muñoz JF, Escobar-Arriaga E, Ulloa-Aguirre A, de Jesús Ibarra-SánchezM (2019), Metformin reverses mesenchymal phenotype of primary breast cancer cells through STAT3/NF- $\kappa$ B pathways. BMC Cancer 19, 1, 728. https://doi.org/10.1186/s12885019-5945-1.

181. Laurentino TS, Soares RDS, Marie SKN, Oba-Shinjo SM (2019), LOXL3 function beyond amino oxidase and role in pathologies, including cancer. Int J Mol Sci 20, 14, pii: E3587. https://doi.org/10.3390/ijms20143587.

182. Huang M, Liu Z, Baugh L, DeFuria J, Maione A, Smith A, Kashpur O, Black Iii LD, Georgakoudi I, Whitfield ML, Garlick J (2019), Lysyl oxidase enzymes mediate TGF- $\beta 1$ induced fibrotic phenotypes in human skin-like tissues. Lab Invest 99, 4, 514-527. https://doi.org/10.1038/s41374-0180159-8. 
183. Kraft-Sheleg O, Zaffryar-Eilot S, Genin O, Yaseen W, Soueid-Baumgarten S, Kessler O, Smolkin T, Akiri G, Neufeld G, Cinnamon Y, Hasson P (2016), Localized LoxL3-dependent fibronectin oxidation regulates myofiber stretch and integrin-mediated adhesion. Dev Cell 36, 5, 550561. https://doi.org/10.1016/j.devcel.2016.02.009.

184. Peinado H, Iglesias-de DelCarmen, la Cruz M, Olmeda D, Csiszar K, Fong KS, Vega S, Nieto MA, Cano A, Portillo F (2005), A molecular role for lysyl oxidase-like 2 enzyme in snail regulation and tumor progression. EMBO J 24, 19, 3446-3458. https://doi.org/10.1038/sj.emboj.7600781.

185. Santamaría PG, Floristán A, Fontanals-Cirera B, VázquezNaharro A, Santos V, Morales S, Yuste L, Peinado H, García-Gómez A, Portillo F, Hernando E, Cano A (2018), Lysyl oxidase-like 3 is required for melanoma cell survival by maintaining genomic stability. Cell Death Differ 25, 5, 935-950. https://doi.org/10.1038/s41418-017-0030-2.

186. Kasashima H, Yashiro M, Okuno T, Miki Y, Kitayama K, Masuda G, Kinoshita H, Morisaki T, Fukuoka T, Hasegawa T, Sakurai K, Toyokawa T, Kubo N, Tanaka H, Muguruma K, Hirakawa K, Ohira M (2018), Significance of the lysyl oxidase members lysyl oxidase like 1,3 , and 4 in gastric cancer. Digestion 98, 4, 238-248. https://doi.org/10.1159/000489558.

187. Lee JE, Kim Y (2006), A tissue-specific variant of the human lysyl oxidase-like protein 3 (LOXL3) functions as an amine oxidase with substrate specificity. J Biol Chem 281, 49, 37282-37290. https://doi.org/10.1074/jbc.M600977200.

188. Zhang Y, Jiao H, Wu Y, Sun X (2019), P120-catenin regulates pulmonary fibrosis and TGF- $\beta$ induced lung fibroblast differentiation. Life Sci 230, 35-44. https://doi. org/10.1016/j.lfs.2019.05.052.

189. Kourtidis A, Ngok SP, Anastasiadis PZ (2013), p120 catenin: an essential regulator of cadherin stability, adhesion-induced signaling, and cancer progression. Prog Mol Biol Transl Sci 116, 409-432. https://doi.org/10.1016/ B978-0-12-394311-8.00018-2.

190. Iyer KV, Piscitello-Gómez R, Paijmans J, Jülicher F, Eaton $\mathrm{S}$ (2019), Epithelial viscoelasticity is regulated by mechanosensitive E-cadherin turnover. Curr Biol 29, 4, 578-591.e5. https://doi.org/10.1016/j.cub.2019.01.021.

191. Stefanatos RK, Bauer C, Vidal M (2013), p120 catenin is required for the stress response in Drosophila. PLoS One 8, 12, e83942. https://doi.org/10.1371/journal.pone.0083942.

192. Venhuizen JH, Sommer S, Span PN, Friedl P, Zegers MM (2019), Differential expression of p120-catenin 1 and 3 isoforms in epithelial tissues. Sci Rep 9, 1, 90. https://doi. org/10.1038/s41598-018-36889-w.

193. Zhang Y, Zhao Y, Jiang G, Zhang X, Zhao H, Wu J, Xu K, Wang E (2014), Impact of p120-catenin isoforms 1A and 3A on epithelial mesenchymal transition of lung cancer cells expressing E-cadherin in different subcellular locations. PLoS One 9, 2, e88064. https://doi.org/10.1371/journal. pone.0088064.

194. Sha Y, Haensel D, Gutierrez G, Du H, Dai X, Nie Q (2019), Intermediate cell states in epithelial-to-mesenchymal transition. Phys Biol 16, 2, 021001. https://doi.org/10.1088/ 1478-3975/aaf928.

195. Pei D, Shu X, Gassama-Diagne A, Thiery JP (2019), Mesenchymal-epithelial transition in development and reprogramming. Nat Cell Biol 21, 1, 44-53. https://doi. org/10.1038/s41556-018-0195-z.

196. Bronfman M, Inestrosa NC, Leighton F (1979), Fatty acid oxidation by human liver peroxisomes. Biochem Biophys Res Commun 88, 3, 1030-1036. PMID: 465070.

197. Tolbert NE, Essner E (1981), Microbodies: peroxisomes and glyoxisomes. J Cell Biol 91, 3 Pt 2, 271s-283s. https://doi. org $/ 10.1083 /$ jcb.91.3.271s.
198. Gerbling H, Gerhardt B (1987), Activation of fatty acids by non-glyoxysomal peroxisomes. Planta 171, 3, 386-392. https://doi.org/10.1007/BF00398684.

199. Berg JM, Tymoczko JL, Stryer L (2002), Section 22.4, fatty acids are synthesized and degraded by different pathways. Biochemistry, 5th edn., WH Freeman, New York. Available from https://www.ncbi.nlm.nih.gov/books/NBK22554/.

200. Meyer D, Herrfurth C, Brodhun F, Feussner I (2013), Degradation of lipoxygenase-derived oxylipins by glyoxysomes from sunflower and cucumber cotyledons. BMC Plant Biol 13, 177. https://doi.org/10.1186/1471-2229-13177.

201. Houten SM, Violante S, Ventura FV, Wanders RJ (2016), The biochemistry and physiology of mitochondrial fatty acid $\beta$-oxidation and its genetic disorders. Annu Rev Physiol 78, 23-44. https://doi.org/10.1146/annurev-physiol-021115-105045.

202. Qiu X, Meesapyodsuk D (2009), Biosynthesis of unusual fatty acids in microorganisms and their production in plants, in: ChT Hou, JF Shaw (Eds.), Biocatalysis and Agricultural Biotechnology, CRC Press. ISBN 9781420077032, 133-142.

203. Klempova T, Mihalik D, Certik M (2013), Characterization of membrane-bound fatty acid desaturases. Gen Physiol Biophys 32, 4, 445-458. https://doi.org/10.4149/ gpb_2013051.

204. Sperling P, Ternes P, Zank TK, Heinz E (2003), The evolution of desaturases. Prostaglandins Leukot Essent Fatty Acids 68, 2, 73-95. PMID: 12538072.

205. Hashimoto K, Yoshizawa AC, Okuda S, Kuma K, Goto S, Kanehisa M (2008), The repertoire of desaturases and elongases reveals fatty acid variations in 56 eukaryotic genomes. J Lipid Res 49, 1, 183-191. https://doi.org/ 10.1194/jlr.M700377-JLR200.

206. Enoch HG, Catalá A, Strittmatter P (1976), Mechanism of rat liver microsomal stearyl-CoA desaturase. Studies of the substrate specificity, enzyme-substrate interactions, and the function of lipid. J Biol Chem 251, 16, 5095-5103, PMID: 8453.

207. Shanklin J, Cahoon EB (1998), Desaturation and related modifications of fatty acids1. Annu Rev Plant Physiol Plant Mol Biol 49, 1, 611-641. https://doi.org/10.1146/annurev. arplant.49.1.611.

208. Castro LF, Wilson JM, Gonçalves O, Galante-Oliveira S, Rocha E, Cunha I (2011), The evolutionary history of the stearoyl-CoA desaturase gene family in vertebrates. BMC Evol Biol 11, 132, 1-14. https://doi.org/10.1186/14712148-11-132.

209. Wada H, Gombos Z, Murata N (1990), Enhancement of chilling tolerance of a cyanobacterium by genetic manipulation of fatty acid desaturation. Nature 347, 6289, 200-203. https://doi.org/10.1038/347200a0.

210. Kodama H, Hamada T, Horiguchi G, Nishimura M, Iba K (1994), Genetic enhancement of cold tolerance by expression of a gene for chloroplast [omega]-3 fatty acid desaturase in transgenic tobacco. Plant Physiol 105, 2, 601-605. https://doi.org/10.1104/pp.105.2.601.

211. Strittmatter P, Enoch HG (1978), Purification of stearylCoA desaturase from liver. Methods Enzymol 52, 188-193. PMID: 27698.

212. Kasturi R, Joshi VC (1982), Hormonal regulation of stearoyl coenzyme A desaturase activity and lipogenesis during adipose conversion of 3T3-L1 cells. J Biol Chem 257, 20, 12224-12230. PMID: 6181064.

213. Ntambi JM, Buhrow SA, Kaestner KH, Christy RJ, Sibley E, Kelly TJ Jr, Lane MD (1988), Differentiation-induced gene expression in 3T3-L1 preadipocytes. Characterization 
of a differentially expressed gene encoding stearoyl-CoA desaturase. J Biol Chem 263, 33, 17291-17300. PMID: 2903162.

214. Ntambi JM (1992), Dietary regulation of stearoyl-CoA desaturase 1 gene expression in mouse liver. J Biol Chem 267, 15, 10925-10930.

215. Hofacer R, Magrisso IJ, Jandacek R, Rider T, Tso P, Benoit SC, McNamara RK (2012), Omega-3 fatty acid deficiency increases stearoyl-CoA desaturase expression and activity indices in rat liver: positive association with non-fasting plasma triglyceride levels. Prostaglandins Leukot Essent Fatty Acids 86, 1-2, 71-77. https://doi.org/10.1016/ j.plefa.2011.10.003.

216. Jastrzebska B, Debinski A, Filipek S, Palczewski K (2011), Role of membrane integrity on $\mathrm{G}$ protein-coupled receptors: Rhodopsin stability and function. Prog Lipid Res 50, 3, 267-277. https://doi.org/10.1016/j.plipres.2011.03.002.

217. Miyazaki M, Dobrzyn A, Sampath H, Lee SH, Man WC, Chu K, Peters JM, Gonzalez FJ, Ntambi JM (2004), Reduced adiposity and liver steatosis by stearoyl-CoA desaturase deficiency are independent of peroxisome proliferator-activated receptor-alpha. J Biol Chem 279, 33, 35017-35024. https://doi.org/10.1074/jbc.M405327200.

218. Brown JM, Chung S, Sawyer JK, Degirolamo C, Alger HM, Nguyen TM, Zhu X, Duong MN, Brown AL, Lord C, Shah R, Davis MA, Kelley K, Wilson MD, Madenspacher J, Fessler MB, Parks JS, Rudel LL (2010), Combined therapy of dietary fish oil and stearoyl-CoA desaturase 1 inhibition prevents the metabolic syndrome and atherosclerosis. Arterioscler Thromb Vasc Biol 30, 1, 24-30. https://doi.org/ 10.1161/ATVBAHA.109.198036.

219. Jiang G, Li Z, Liu F, Ellsworth K, Dallas-Yang Q, Wu M, Ronan J, Esau C, Murphy C, Szalkowski D, Bergeron R, Doebber T, Zhang BB (2005), Prevention of obesity in mice by antisense oligonucleotide inhibitors of stearoyl-CoA desaturase-1. J Clin Invest 115, 4, 1030-1038. https://doi. org/10.1172/JCI23962. Erratum (2005) J Clin Invest 115, 8, 2297.

220. Miyazaki M, Sampath H, Liu X, Flowers MT, Chu K, Dobrzyn A, Ntambi JM (2009), Stearoyl-CoA desaturase-1 deficiency attenuates obesity and insulin resistance in leptinresistant obese mice. Biochem Biophys Res Commun 380, 4, 818-822. https://doi.org/10.1016/j.bbrc.2009.01.183.

221. Liu X, Miyazaki M, Flowers MT, Sampath H, Zhao M, Chu K, Paton CM, Joo DS, Ntambi JM (2010), Loss of StearoylCoA desaturase-1 attenuates adipocyte inflammation: effects of adipocyte-derived oleate. Arterioscler Thromb Vasc Biol 30, 1, 31-38. https://doi.org/10.1161/ATVBAHA.109.195636. Erratum (2010) Arterioscler Thromb Vasc Biol 30, 10, e177.

222. Mauvoisin D, Charfi C, Lounis AM, Rassart E, Mounier C (2013), Decreasing stearoyl-CoA desaturase-1 expression inhibits $\beta$-catenin signaling in breast cancer cells. Cancer Sci 104, 1, 36-42. https://doi.org/10.1111/cas.12032.

223. Imamura K, Tomita N, Kawakita Y, Ito Y, Ono K, Nii N, Miyazaki T, Yonemori K, Tawada M, Sumi H, Satoh Y, Yamamoto Y, Miyahisa I, Sasaki M, Satomi Y, Hirayama M, Nishigaki R, Maezaki H (2017), Discovery of novel and potent Stearoyl Coenzyme A Desaturase 1 (SCD1) inhibitors as anticancer agents. Bioorg Med Chem 25, 14, 37683779. https://doi.org/10.1016/j.bmc.2017.05.016.

224. Dobrzyn P, Dobrzyn A, Miyazaki M, Cohen P, Asilmaz E, Hardie DG, Friedman JM, Ntambi JM (2004), StearoylCoA desaturase 1 deficiency increases fatty acid oxidation by activating AMP-activated protein kinase in liver. Proc Natl Acad Sci USA 101, 17, 6409-6414. https://doi.org/ 10.1073/pnas.0401627101.
225. Scaglia N, Chisholm JW, Igal RA (2009), Inhibition of stearoylCoA desaturase-1 inactivates acetyl-CoA carboxylase and impairs proliferation in cancer cells: role of AMPK. PLoS One 4, 8, e6812. https://doi.org/10.1371/journal. pone.0006812.

226. Waters KM, Ntambi JM (1994), Insulin and dietary fructose induce stearoyl-CoA desaturase 1 gene expression of diabetic mice. J Biol Chem 269, 44, 27773-27777. PMID: 7961698.

227. Miller CW, Waters KM, Ntambi JM (1997), Regulation of hepatic stearoyl-CoA desaturase gene 1 by vitamin A. Biochem Biophys Res Commun 231, 1, 206-210. https://doi.org/10.1006/bbrc.1997.6070.

228. Waters KM, Miller CW, Ntambi JM (1997), Localization of a negative thyroid hormone-response region in hepatic stearoyl-CoA desaturase gene 1. Biochem Biophys Res Commun 233, 3, 838-843. https://doi.org/10.1006/bbrc. 1997.6550.

229. Biddinger SB, Miyazaki M, Boucher J, Ntambi JM, Kahn CR (2006), Leptin suppresses stearoyl-CoA desaturase 1 by mechanisms independent of insulin and sterol regulatory element-binding protein-1c. Diabetes 55, 7, 2032-2041. https://doi.org/10.2337/db05-0742.

230. Mauvoisin D, Rocque G, Arfa O, Radenne A, Boissier P, Mounier C (2007), Role of the PI3-kinase/mTor pathway in the regulation of the stearoyl CoA desaturase (SCD1) gene expression by insulin in liver. J Cell Commun Signal 1, 2, 113-125. https://doi.org/10.1007/s12079-007-0011-1.

231. Düvel K, Yecies JL, Menon S, Raman P, Lipovsky AI, Souza AL, Triantafellow E, Ma Q, Gorski R, Cleaver S, Vander Heiden MG, MacKeigan JP, Finan PM, Clish CB, Murphy LO, Manning BD (2010), Activation of a metabolic gene regulatory network downstream of mTOR complex 1 . Mol Cell 39, 2, 171-183. https://doi.org/10.1016/ j.molcel.2010.06.022.

232. Luyimbazi D, Akcakanat A, McAuliffe PF, Zhang L, Singh G, Gonzalez-Angulo AM, Chen H, Do KA, Zheng Y, Hung MC, Mills GB, Meric-Bernstam F (2010), Rapamycin regulates stearoyl CoA desaturase 1 expression in breast cancer. Mol Cancer Ther 9, 10, 2770-2784. https://doi.org/10.1158/1535-7163.MCT-09-0980.

233. Peterson TR, Sengupta SS, Harris TE, Carmack AE, Kang SA, Balderas E, Guertin DA, Madden KL, Carpenter AE, Finck BN, Sabatini DM (2011), mTOR complex 1 regulates lipin 1 localization to control the SREBP pathway. Cell 146, 3, 408-420. https://doi.org/10.1016/j.cell.2011.06.034.

234. Zhang J, Song F, Zhao X, Jiang H, Wu X, Wang B, Zhou M, Tian M, Shi B, Wang H, Jia Y, Wang H, Pan X, Li Z (2017), EGFR modulates monounsaturated fatty acid synthesis through phosphorylation of SCD1 in lung cancer. Mol Cancer 16, 1, 127. https://doi.org/10.1186/s12943-0170704-x.

235. Nashed M, Chisholm JW, Igal RA (2012), Stearoyl-CoA desaturase activity modulates the activation of epidermal growth factor receptor in human lung cancer cells. Exp Biol Med (Maywood) 237, 9, 1007-1017https://doi.org/ 10.1258/ebm.2012.012126.

236. She K, Fang S, Du W, Fan X, He J, Pan H, Huang L, He P, Huang J (2019), SCD1 is required for EGFR-targeting cancer therapy of lung cancer via re-activation of EGFR/ PI3K/AKT signals. Cancer Cell Int 19, 103. https://doi. org/10.1186/s12935-019-0809-y.

237. Li J, Condello S, Thomes-Pepin J, Ma X, Xia Y, Hurley TD, Matei D, Cheng JX (2017), Lipid desaturation is a metabolic marker and therapeutic target of ovarian cancer stem cells. Cell Stem Cell 20, 3, 303-314, e5. https://doi. org $/ 10.1016 /$ j.stem.2016.11.004. 
238. Lu H, Lei X, Zhang Q (2015), Moderate activation of IKK2$\mathrm{NF}-\mathrm{kB}$ in unstressed adult mouse liver induces cytoprotective genes and lipogenesis without apparent signs of inflammation or fibrosis. BMC Gastroenterol 15, 94. https://doi.org/10.1186/s12876-015-0325-z.

239. Zhang Q, Yu S, Lam MMT, Poon TCW, Sun L, Jiao Y, Wong AST, Lee LTO (2019), Angiotensin II promotes ovarian cancer spheroid formation and metastasis by upregulation of lipid desaturation and suppression of endoplasmic reticulum stress. J Exp Clin Cancer Res 38, 1, 116. https://doi.org/10.1186/s13046-019-1127-x.

240. Roongta UV, Pabalan JG, Wang X, Ryseck RP, Fargnoli J, Henley BJ, Yang WP, Zhu J, Madireddi MT, Lawrence RM, Wong TW, Rupnow BA (2011), Cancer cell dependence on unsaturated fatty acids implicates stearoyl-CoA desaturase as a target for cancer therapy. Mol Cancer Res 9, 11, 1551-1561. https://doi.org/10.1158/1541-7786.MCR11-0126.

241. Huang J, Fan XX, He J, Pan H, Li RZ, Huang L, Jiang Z, Yao XJ, Liu L, Leung EL, He JX (2016), SCD1 is associated with tumor promotion, late stage and poor survival in lung adenocarcinoma. Oncotarget 7, 26, 39970-39979. https://doi.org/10.18632/oncotarget.9461.

242. Liu G, Feng S, Jia L, Wang C, Fu Y, Luo Y (2018), Lung fibroblasts promote metastatic colonization through upregulation of stearoyl-CoA desaturase 1 in tumor cells. Oncogene 37, 11, 1519-1533. https://doi.org/10.1038/s41388017-0062-6.

243. Scaglia N, Caviglia JM, Igal RA (2005), High stearoyl-CoA desaturase protein and activity levels in simian virus 40 transformed-human lung fibroblasts. Biochim Biophys Acta 1687, 1-3, 141-151. https://doi.org/10.1016/j. bbalip.2004.11.015.

244. Holder AM, Gonzalez-Angulo AM, Chen H, Akcakanat A, Do KA, Fraser Symmans W, Pusztai L, Hortobagyi GN, Mills GB, Meric-Bernstam F (2013), High stearoyl-CoA desaturase 1 expression is associated with shorter survival in breast cancer patients. Breast Cancer Res Treat 137, 1, 319-327. https://doi.org/10.1007/s10549-012-2354-4.

245. Ide Y, Waki M, Hayasaka T, Nishio T, Morita Y, Tanaka H, Sasaki T, Koizumi K, Matsunuma R, Hosokawa Y, Ogura H, Shiiya N, Setou M (2013), Human breast cancer tissues contain abundant phosphatidylcholine(36:1) with high stearoyl-CoA desaturase-1 expression. PLoS One 8, 4, e61204. https://doi.org/10.1371/journal.pone.0061204. Correction: Plos One 8, 9. DOI: https://doi.org/10.1371/ annotation/63c5359c-b1d2-44d8-944f-7bde0d6ec946.

246. Pampalakis G, Politi AL, Papanastasiou A, Sotiropoulou G (2015), Distinct cholesterogenic and lipidogenic gene expression patterns in ovarian cancer - a new pool of biomarkers. Genes Cancer 6, 11-12, 472-479. https://doi.org/ 10.18632 /genesandcancer.87.

247. von Roemeling CA, Marlow LA, Pinkerton AB, Crist A, Miller J, Tun HW, Smallridge RC, Copland JA (2015), Aberrant lipid metabolism in anaplastic thyroid carcinoma reveals stearoyl CoA desaturase 1 as a novel therapeutic target. J Clin Endocrinol Metab 100, 5, E697-709. https://doi.org/10.1210/jc.2014-2764.

248. Li J, Ding SF, Habib NA, Fermor BF, Wood CB, Gilmour RS (1994), Partial characterization of a cDNA for human stearoyl-CoA desaturase and changes in its mRNA expression in some normal and malignant tissues. Int J Cancer 57, 3, 348-352. https://doi.org/10.1002/ijc.2910570310.

249. Mason P, Liang B, Li L, Fremgen T, Murphy E, Quinn A, Madden SL, Biemann HP, Wang B, Cohen A, Komarnitsky S, Jancsics K, Hirth B, Cooper CG, Lee E,
Wilson S, Krumbholz R, Schmid S, Xiang Y, Booker M, Lillie J, Carter K (2012), SCD1 inhibition causes cancer cell death by depleting mono-unsaturated fatty acids. PLoS One 7, 3, e33823. https://doi.org/10.1371/journal.pone.0033823.

250. Vargas T, Moreno-Rubio J, Herranz J, Cejas P, Molina S, González-Vallinas M, Mendiola M, Burgos E, Aguayo C, Custodio AB, Machado I, Ramos D, Gironella M, EspinosaSalinas I, Ramos R, Martín-Hernández R, Risueño A, De Las RivasJ, Reglero G, Yaya R, Fernández-Martos C, Aparicio J, Maurel J, Feliu J, Ramírez de Molina A (2015), ColoLipidGene: signature of lipid metabolism-related genes to predict prognosis in stage-II colon cancer patients. Oncotarget 6, 9, 7348-7363. https://doi.org/10.18632/ oncotarget.3130.

251. Falvella FS, Pascale RM, Gariboldi M, Manenti G, De Miglio MR, Simile MM, Dragani TA, Feo F (2002), Stearoyl-CoA desaturase 1 ( $\mathrm{Scd} 1)$ gene overexpression is associated with genetic predisposition to hepatocarcinogenesis in mice and rats. Carcinogenesis 23, 11, 1933-1936. https://doi.org/10.1093/carcin/23.11.1933.

252. Yahagi N, Shimano H, Hasegawa K, Ohashi K, Matsuzaka T, Najima Y, Sekiya M, Tomita S, Okazaki H, Tamura Y, Iizuka Y, Nagai R, Ishibashi S, Kadowaki T, Makuuchi M, Ohnishi S, Osuga J, Yamada N (2005), Coordinate activation of lipogenic enzymes in hepatocellular carcinoma. Eur J Cancer 41, 9, 1316-1322. https://doi.org/10.1016/j. ejca.2004.12.037.

253. Scaglia N, Igal RA (2008), Inhibition of Stearoyl-CoA Desaturase 1 expression in human lung adenocarcinoma cells impairs tumorigenesis. Int J Oncol 33, 4, 839-850. PMID: 18813799.

254. Hess D, Chisholm JW, Igal RA (2019), Inhibition of stearoylCoA desaturase activity blocks cell cycle progression and induces programmed cell death in lung cancer cells. PLoS One 5, 6, e11394. https://doi.org/10.1371/journal. pone.0011394.

255. Noto A, Raffa S, De Vitis C, Roscilli G, Malpicci D, Coluccia P, Di Napoli A, Ricci A, Giovagnoli MR, Aurisicchio L, Torrisi MR, Ciliberto G, Mancini R (2013), Stearoyl-CoA desaturase-1 is a key factor for lung cancerinitiating cells. Cell Death Dis 4, e947, 1-11. https://doi. org $/ 10.1038 /$ cddis.2013.444.

256. Wang J, Xu Y, Zhu L, Zou Y, Kong W, Dong B, Huang J, Chen Y, Xue W, Huang Y, Zhang J (2016), High expression of Stearoyl-CoA Desaturase 1 predicts poor prognosis in patients with clear-cell renal cell carcinoma. PLoS One 11, 11, e0166231. https://doi.org/10.1371/journal. pone. 0166231.

257. Fritz V, Benfodda Z, Gv Rodier, Henriquet C, Fo Iborra, Avancès C, Allory Y, de la Taille A, Sp Culine, Blancou H, Cristol JP, Fo Michel, Sardet C, Fajas L (2010), Abrogation of de novo lipogenesis by Stearoyl-CoA Desaturase 1 Inhibition interferes with oncogenic signaling and blocks prostate cancer progression in mice. Mol Cancer Ther 9, 6, 1740-1754. https://doi.org/10.1158/1535-7163.mct-09-1064.

258. Pisanu ME, Maugeri-Saccà M, Fattore L, Bruschini S, De Vitis C, Tabbì E, Bellei B, Migliano E, Kovacs D, Camera E, Picardo M, Jakopin Z, Cippitelli C, Bartolazzi A, Raffa S, Torrisi MR, Fulciniti F, Ascierto PA, Ciliberto G, Mancini R (2018), Inhibition of Stearoyl-CoA desaturase 1 reverts BRAF and MEK inhibition-induced selection of cancer stem cells in BRAF-mutated melanoma. J Exp Clin Cancer Res 37, 1, 318. https://doi.org/10.1186/s13046-0180989-7.

259. Nicolaides N (1974), Skin lipids: their biochemical uniqueness. Science 186, 4, 19-26. PMID: 4607408. 
260. Ge L, Gordon JS, Hsuan C, Stenn K, Prouty SM (2003), Identification of the delta- 6 desaturase of human sebaceous glands: expression and enzyme activity. J Invest Dermatol 120, 5, 707-714. https://doi.org/10.1046/j.1523-1747.2003. 12123.x. Erratum (2003) J Invest Dermatol 121, 2, 434.

261. Snaebjornsson MT, Schulze A (2019), Tumours use a metabolic twist to make lipids. Nature 566, 7744, 333-334. https://doi.org/10.1038/d41586-019-00352-1.

262. Jeffcoat R, Brawn PR, James AT (1976), The effect of soluble rat liver proteins on the activity of microsomal stearoyl-CoA and linoleoyl-CoA desaturase. Biochim Biophys Acta 431, 1, 33-44. PMID: 5153.

263. Marquardt A, Stöhr H, White K, Weber BH (2000), cDNA cloning, genomic structure, and chromosomal localization of three members of the human fatty acid desaturase family. Genomics 66, 2, 175-183. https://doi.org/10.1006/ geno.2000.6196.

264. Tang C, Cho HP, Nakamura MT, Clarke SD (2003), Regulation of human delta-6 desaturase gene transcription: identification of a functional direct repeat-1 element. J Lipid Res 44, 4, 686-695. https://doi.org/10.1194/jlr.M200195JLR200.

265. Vriens K, Christen S, Parik S, Broekaert D, Yoshinaga K, Talebi A, Dehairs J, Escalona-Noguero C, Schmieder R, Cornfield T, Charlton C, Romero-Pérez L, Rossi M, Rinaldi G, Orth MF, Boon R, Kerstens A, Kwan SY, Faubert B, Méndez-Lucas A, Kopitz CC, Chen T, Fernandez-Garcia J, Duarte JAG, Schmitz AA, Steigemann P, Najimi M, Hägebarth A, Van Ginderachter JA, Sokal E, Gotoh N, Wong KK, Verfaillie C, Derua R, Munck S, Yuneva M, Beretta L, DeBerardinis RJ, Swinnen JV, Hodson L, Cassiman D, Verslype C, Christian S, Grünewald S, Grünewald TGP, Fendt SM (2019), Evidence for an alternative fatty acid desaturation pathway increasing cancer plasticity. Nature 566, 7744, 403-406. https://doi. org/10.1038/s41586-019-0904-1.

266. Lee CK, Jeong SH, Jang C, Bae H, Kim YH, Park I, Kim SK, Koh GY (2019), Tumor metastasis to lymph nodes requires YAP-dependent metabolic pathway. Science 363, 6427, 644-649. https://doi.org/10.1126/science. aav0173.

267. Park YY, Sohn BH, Johnson RL, Kang MH, Kim SB, Shim JJ, Mangala LS, Kim JH, Yoo JE, Rodriguez-Aguayo C, Pradeep S, Hwang JE, Jang HJ, Lee HS, Rupaimoole R, Lopez-Berestein G, Jeong W, Park IS, Park YN, Sood AK, Mills GB, Lee JS (2016), Yes-associated protein 1 and transcriptional coactivator with PDZ-binding motif activate the mammalian target of rapamycin complex 1 pathway by regulating amino acid transporters in hepatocellular carcinoma. Hepatology 63, 1, 159-172. https://doi. org/10.1002/hep.28223.

268. Li H, He F, Zhao X, Zhang Y, Chu X, Hua C, Qu Y, Duan Y, Ming L (2017), YAP inhibits the apoptosis and migration of human rectal cancer cells via suppression of JNK-Drp1-mitochondrial fission-HtrA2/omi pathways. Cell Physiol Biochem 44, 5, 2073-2089. https://doi.org/ $10.1159 / 000485946$.

269. Zhang X, Abdelrahman A, Vollmar B, Zechner D (2018), The ambivalent function of YAP in apoptosis and cancer. Int J Mol Sci 19, 12, pii: E3770. https://doi.org/10.3390/ ijms19123770

270. Roedig P, Ginn HM, Pakendorf T, Sutton G, Harlos K, Walter TS, Meyer J, Fischer P, Duman R, Vartiainen I, Reime B, Warmer M, Brewster AS, Young ID, MichelsClark T, Sauter NK, Kotecha A, Kelly J, Rowlands DJ, Sikorsky M, Nelson S, Damiani DS, Alonso-Mori R, Ren J, Fry EE, David C, Stuart DI, Wagner A, Meents A (2017),
High-speed fixed-target serial virus crystallography. Nat Methods 14, 805-810. https://doi.org/10.1038/nmeth.4335.

271. Peng T, Thorn K, Schroeder T, Wang L, Theis FJ, Marr C, Navab N (2017), A BaSiC tool for background and shading correction of optical microscopy images. Nat Commun 8, 14836. https://doi.org/10.1038/ncomms14836.

272. Gaglia JL, Harisinghani M, Aganj I, Wojtkiewicz GR, Hedgire S, Benoist C, Mathis D, Weissleder R (2015), Noninvasive mapping of pancreatic inflammation in recentonset type-1 diabetes patients. Proc Natl Acad Sci USA 112, 7, 2139-2144. https://doi.org/10.1073/pnas.1424993112.

273. Balogh LP (2015), Caging cancer. Nanomedicine 11, 4, 867-869. https://doi.org/10.1016/j.nano.2015.02.005.

274. Eliscovich C, Shenoy SM, Singer RH (2017), Imaging mRNA and protein interactions within neurons. Proc Natl Acad Sci USA 114, 10, E1875-E1884. https://doi.org/ 10.1073 /pnas. 1621440114 .

275. Luo JL, Tan W, Ricono JM, Korchynskyi O, Zhang M, Gonias SL, Cheresh DA, Karin M (2007), Nuclear cytokineactivated IKK $\alpha$ controls prostate cancer metastasis by repressing Maspin. Nature 446, 7136, 690-694. https://doi. org/10.1038/nature05656.

276. Affara NI, Coussens LM (2007), IKKalpha at the crossroads of inflammation and metastasis. Cell 129, 1, 25-26. https://doi.org/10.1016/j.cell.2007.03.029.

277. Blanke ML, VanDongen AMJ (2009), Activation mechanisms of the NMDA receptor, in: AM Van Dongen (Ed.), Biology of the NMDA Receptor, CRC Press/Taylor \& Francis, Boca Raton, FL, Chapter 13. Available from https://www.ncbi.nlm.nih.gov/books/NBK5274/.

278. Marquard J, Otter S, Welters A, Stirban A, Fischer A, Eglinger J, Herebian D, Kletke O, Klemen MS, Stožer A, Wnendt S, Piemonti L, Köhler M, Ferrer J, Thorens B, Schliess F, Rupnik MS, Heise T, Berggren PO, Klöcker N, Meissner T, Mayatepek E, Eberhard D, Kragl M, Lammert E (2015), Characterization of pancreatic NMDA receptors as possible drug targets for diabetes treatment. Nat Med 21, 4, 363-372. https://doi.org/10.1038/nm.3822.

279. Leanza L, Managò A, Zoratti M, Gulbins E, Szabo I (2016), Pharmacological targeting of ion channels for cancer therapy: in vivo evidences. Biochim Biophys Acta 1863, 6 Pt B, 1385-1397. https://doi.org/10.1016/j.bbamcr.2015.11.032.

280. Aboel Dahab A, El-Hag D, Moutamed GM, Aboel Dahab S, Abuknesha R, Smith NW (2016), Pharmacokinetic variations in cancer patients with liver dysfunction: applications and challenges of pharmacometabolomics. Cancer Chemother Pharmacol 78, 3, 465-489. https://doi.org/ 10.1007/s00280-016-3028-4.

281. Burt A (2003), Site-specific selfish genes as tools for the control and genetic engineering of natural populations. Proc Biol Sci 270, 1518, 921-928. https://doi.org/10.1098/ rspb.2002.2319.

282. Gantz VM, Bier E (2015), Genome editing. The mutagenic chain reaction: A method for converting heterozygous to homozygous mutations. Science 348, 6233, 442-444. https://doi.org/10.1126/science.aaa5945.

283. Champer JR, Reeves R, Oh SY, Liu C, Liu J, Clark AG, Messer PW (2017), Novel CRISPR/Cas9 gene drive constructs reveal insights into mechanisms of resistance allele formation and drive efficiency in genetically diverse populations. PLoS Genet 13, 7, e1006796. https://doi.org/ 10.1371/journal.pgen.1006796.

284. Bull JJ, Malik HS (2017), The gene drive bubble: New realities. PLoS Genet 13, 7, e1006850. https://doi.org/ 10.1371/journal.pgen.1006850.

285. Smith DF, Faber LE, Toft DO (1990), Purification of unactivated progesterone receptor and identification of 
novel receptor-associated proteins. J Biol Chem 265, 7, 3996-4003. PMID: 2303491.

286. Baughman G, Wiederrecht GJ, Campbell NF, Martin MM, Bourgeois S (1995), FKBP51, a novel T-cell-specific immunophilin capable of calcineurin inhibition. Mol Cell Biol 15, 8, 4395-4402. https://doi.org/10.1128/MCB.15.8.4395.

287. Maki N, Sekiguchi F, Nishimaki J, Miwa K, Hayano T, Takahashi N, Suzuki M (1990), Complementary DNA encoding the human T-cell FK506-binding protein, a peptidylprolyl cis-trans isomerase distinct from cyclophilin. Proc Natl Acad Sci USA 87, 14, 5440-5443. https://doi. org $/ 10.1073 /$ pnas.87.14.5440.

288. Wiederrecht G, Hung S, Chan HK, Marcy A, Martin M, Calaycay J, Boulton D, Sigal N, Kincaid RL, Siekierka JJ (1992), Characterization of high molecular weight FK-506 binding activities reveals a novel FK-506-binding protein as well as a protein complex. J Biol Chem 267, 30, 2175321760.

289. Ebong IO, Beilsten-Edmands V, Patel NA, Morgner N, Robinson CV (2016), The interchange of immunophilins leads to parallel pathways and different intermediates in the assembly of Hsp90 glucocorticoid receptor complexes. Cell Discov 2, 16002. https://doi.org/10.1038/celldisc.2016.2. eCollection 2016. https://doi.org/10.1038/celldisc.2016.2.

290. Fries GR, Gassen NC, Rein T (2017), The FKBP51 glucocorticoid receptor co-chaperone: Regulation, function, and implications in health and disease. Int J Mol Sci 18, 12, pii: E2614. https://doi.org/10.3390/ijms18122614.

291. Gassen NC, Hartmann J, Zschocke J, Stepan J, Hafner K, Zellner A, Kirmeier T, Kollmannsberger L, Wagner KV, Dedic N, Balsevich G, Deussing JM, Kloiber S, Lucae S, Holsboer F, Eder M, Uhr M, Ising M, Schmidt MV, Rein T (2014), Association of FKBP51 with priming of autophagy pathways and mediation of antidepressant treatment response: evidence in cells, mice, and humans. PLoS Med 11, 11, e1001755. https://doi.org/10.1371/journal. pmed.1001755.

292. Balsevich G, Häusl AS, Meyer CW, Karamihalev S, Feng X, Pöhlmann ML, Dournes C, Uribe-Marino A, Santarelli S, Labermaier C, Hafner K, Mao T, Breitsamer M, Theodoropoulou M, Namendorf C, Uhr M, Paez-Pereda M, Winter G, Hausch F, Chen A, Tschöp MH, Rein T, Gassen NC, Schmidt MV (2017), Stress-responsive FKBP51 regulates AKT2-AS160 signaling and metabolic function. Nat Commun 8, 1, 1725. https://doi.org/10.1038/s41467017-01783-y.

293. Kotliarova S, Pastorino S, Kovell LC, Kotliarov Y, Song H, Zhang W, Bailey R, Maric D, Zenklusen JC, Lee J, Fine HA (2008), Glycogen synthase kinase-3 inhibition induces glioma cell death through c-MYC, nuclear factor-kappaB, and glucose regulation. Cancer Res 68, 16, 6643-6651. https://doi.org/10.1158/0008-5472.CAN-08-0850.

294. Gassen NC, Hartmann J, Zannas AS, Kretzschmar A, Zschocke J, Maccarrone G, Hafner K, Zellner A, Kollmannsberger LK, Wagner KV, Mehta D, Kloiber S, Turck CW, Lucae S, Chrousos GP, Holsboer F, Binder EB, Ising M, Schmidt MV, Rein T (2016), FKBP51 inhibits GSK3 $\beta$ and augments the effects of distinct psychotropic medications. Mol Psychiatry 21, 2, 277-289. https://doi.org/ $10.1038 / \mathrm{mp} .2015 .38$.

295. Trackman PC, Bais MV (2018), Measurement of lysyl oxidase activity from small tissue samples and cell cultures. Methods Cell Biol 143, 147-156. https://doi.org/10.1016/ bs.mcb.2017.08.009.

296. Csiszar K (2001), Lysyl oxidases: a novel multifunctional amine oxidase family. Prog Nucleic Acid Res Mol Biol 70, 132. PMID: 11642359.
297. Yamauchi M, Taga Y, Hattori S, Shiiba M, Terajima M (2018), Analysis of collagen and elastin cross-links. Methods Cell Biol 143, 115-132. https://doi.org/10.1016/bs. mcb.2017.08.006.

298. Salvador F, Martin A, López-Menéndez C, Moreno-Bueno G, Santos V, Vázquez-Naharro A, Santamaria PG, Morales S, Dubus PR, Muinelo-Romay L, López-López R, Tung JC, Weaver VM, Portillo F, Cano A (2017), Lysyl oxidase-like protein LOXL2 promotes lung metastasis of breast cancer. Cancer Res 77, 21, 5846-5859. https://doi.org/10.1158/ 0008-5472.CAN-16-3152.

299. Martin A, Salvador F, Moreno-Bueno G, Floristán A, Ruiz-Herguido C, Cuevas EP, Morales S, Santos V, Csiszar K, Dubus P, Haigh JJ, Bigas A, Portillo F, Cano A (2015), Lysyl oxidase-like 2 represses Notch1 expression in the skin to promote squamous cell carcinoma progression. EMBO J 34, 8, 1090-1109. https://doi.org/10.15252/ embj.201489975.

300. Wei Y, Kim TJ, Peng DH, Duan D, Gibbons DL, Yamauchi M, Jackson JR, Le Saux CJ, Calhoun C, Peters J, Derynck R, Backes BJ, Chapman HA (2017), Fibroblast-specific inhibition of TGF- $\beta 1$ signaling attenuates lung and tumor fibrosis. J Clin Invest 127, 10, 3675-3688. https://doi.org/ 10.1172/JCI94624.

301. Ikenaga N, Peng ZW, Vaid KA, Liu SB, Yoshida S, Sverdlov DY, Mikels-Vigdal A, Smith V, Schuppan D, Popov YV (2017), Selective targeting of lysyl oxidase-like 2 (LOXL2) suppresses hepatic fibrosis progression and accelerates its reversal. Gut 66, 9, 1697-1708. https://doi.org/ 10.1136/gutjnl-2016-312473.

302. De La Cruz MS, Buchanan EM (2017), Uterine fibroids: diagnosis and treatment. Am Fam Physician 95, 2, 100-107. PMID: 28084714.

303. Desai VB, Wright JD, Gross CP, Lin H, Boscoe FP, Hutchison LM, Schwartz PE, Xu X (2019), Prevalence, characteristics, and risk factors of occult uterine cancer in presumed benign hysterectomy. Am J Obstet Gynecol 221, 1, 39.e1-39.e14. https://doi.org/10.1016/j.ajog.2019.02.051.

304. Shen Z, Li S, Sheng B, Shen Q, Sun LZ, Zhu H, Zhu X (2018), The role of atorvastatin in suppressing tumor growth of uterine fibroids. J Transl Med 16, 1, 53. https://doi.org/10.1186/s12967-018-1430-x.

305. Murphy JE, Wo JYL, Ferrone C, Jiang W, Yeap BY, Blaszkowsky LS (2017), TGF-B1 inhibition with losartan in combination with FOLFIRINOX (F-NOX) in locally advanced pancreatic cancer (LAPC): Preliminary feasibility and $\mathrm{R} 0$ resection rates from a prospective phase II study. J Clin Oncol 35, 4 SUPPL, 386-386. https://ascopubs. org/doi/abs/10.1200/JCO.2017.35.4_suppl.386.

306. Kumar V, Boucher Y, Liu H, Ferreira D, Hooker J, Catana C, Hoover AJ, Ritter T, Jain RK, Guimaraes AR (2016), Noninvasive assessment of losartan-induced increase in functional microvasculature and drug delivery in pancreatic ductal adenocarcinoma. Transl Oncol 9, 5, 431-437. https://doi.org/10.1016/j.tranon.2016.07.004.

307. Raghu G, Brown KK, Collard HR, Cottin V, Gibson KF, Kaner RJ, Lederer DJ, Martinez FJ, Noble PW, Song JW, Wells AU, Whelan TP, Wuyts W, Moreau E, Patterson SD, Smith V, Bayly S, Chien JW, Gong Q, Zhang JJ, O'Riordan TG (2017), Efficacy of simtuzumab versus placebo in patients with idiopathic pulmonary fibrosis: a randomised, double-blind, controlled, phase 2 trial. Lancet Respir Med 5, 1, 22-32. https://doi.org/ 10.1016/S2213-2600(16)30421-0.

308. Lv GQ, Zou HY, Liao LD, Cao HH, Zeng FM, Wu BL, Xie JJ, Fang WK, Xu LY, Li EM (2014), Identification of a novel lysyl oxidase-like 2 alternative splicing isoform, 
LOXL2 $\Delta$ e13, in esophageal squamous cell carcinoma. Biochem Cell Biol 92, 5, 379-389. https://doi.org/ 10.1139/bcb-2014-0046.

309. Drews HJ, Yenkoyan K, Lourhmati A, Buadze M, Kabisch D, Verleysdonk S, Petschak S, Beer-Hammer S, Davtyan T, Frey WH 2nd, Gleiter CH, Schwab M, Danielyan L (2019), Intranasal losartan decreases perivascular beta amyloid, inflammation, and the decline of neurogenesis in hypertensive rats. Neurotherapeutics 16, 3, 725-740. https://doi. org/10.1007/s13311-019-00723-6.

310. Sherman MH, Yu RT, Engle DD, Ding N, Atkins AR, Tiriac H, Collisson EA, Connor F, Van Dyke T, Kozlov S, Martin P, Tseng TW, Dawson DW, Donahue TR, Masamune A, Shimosegawa T, Apte MV, Wilson JS, Ng B, Lau SL, Gunton JE, Wahl GM, Hunter T, Drebin JA, O'Dwyer PJ, Liddle C, Tuveson DA, Downes M, Evans RM (2014), Vitamin D receptor-mediated stromal reprogramming suppresses pancreatitis and enhances pancreatic cancer therapy. Cell 159, 1, 80-93. https://doi.org/ 10.1016/j.cell.2014.08.007.

311. Uzawa K, Marshall MK, Katz EP, Tanzawa H, Yeowell HN, Yamauchi M (1998), Altered posttranslational modifications of collagen in keloid. Biochem Biophys Res Commun 249, 3, 652-655. https://doi.org/10.1006/bbrc.1998.8955.

312. Minabe M, Kodama T, Kogou T, Tamura T, Hori T, Watanabe Y, Miyata T (1989), Different cross-linked types of collagen implanted in rat palatal gingiva. J Periodontol 60, 1, 35-43. https://doi.org/10.1902/jop.1989.60.1.35.

313. Herschkowitz JI, Simin K, Weigman VJ, Mikaelian I, Usary J, Hu Z, Rasmussen KE, Jones LP, Assefnia S, Chandrasekharan S, Backlund MG, Yin Y, Khramtsov AI, Bastein R, Quackenbush J, Glazer RI, Brown PH, Green JE, Kopelovich L, Furth PA, Palazzo JP, Olopade OI, Bernard PS, Churchill GA, Van Dyke T, Perou CM (2007), Identification of conserved gene expression features between murine mammary carcinoma models and human breast tumors. Genome Biol 8, 5, R76. https://doi.org/10.1186/ gb-2007-8-5-r76.

314. Janssens J (2016), The paradigms in breast cancer prevention, in: J Russo (Ed.), Trends in Breast Cancer Prevention, Springer, Cham. Online ISBN 978-3-319-27135-4.

315. Huang C, Liu H, Gong X, Wen B, Chen D, Liu J, Hu F (2016), Analysis of different components in the peritumoral tissue microenvironment of colorectal cancer: A potential prospect in tumorigenesis. Mol Med Rep 14, 2555-2565. https://doi.org/10.3892/mmr.2016.5584; Corrigendum: https://doi.org/10.3892/mmr.2016.5882.

316. Li L, Zhang W, Shi WY, Ma KT, Zhao L, Wang Y, Zhang L, Li XZ, Zhu H, Zhang ZS, Liu WD, Si JQ (2015), The enhancement of $\mathrm{Cx} 45$ expression and function in renal interlobar artery of spontaneously hypertensive rats at different age. Kidney Blood Press Res 40, 52-65. https://doi.org/10.1159/000368482.

317. Frigge T, Hafke B, Witte T, Krenzer B, Streubühr C, Samad Syed A, Mikšić Trontl V, Avigo I, Zhou P, Ligges M, von der Linde D, Bovensiepen U, Horn-von Hoegen M, Wippermann S, Lücke A, Sanna S, Gerstmann U, Schmidt WG (2017), Optically excited structural transition in atomic wires on surfaces at the quantum limit. Nature 544, 7649, 207-211. https://doi.org/10.1038/nature21432.

318. Chiavazzo E, Covino R, Coifman RR, Gear CW, Georgiou AS, Hummer G, Kevrekidis IG (2017), Intrinsic map dynamics exploration for uncharted effective free-energy landscapes. Proc Natl Acad Sci USA 114, 28, E5494-E5503. https://doi.org/10.1073/pnas.1621481114.

319. Baudrimont A, Voegeli S, Viloria EC, Stritt F, Lenon M, Wada T, Jaquet V, Becskei A (2017), Multiplexed gene control reveals rapid mRNA turnover. Sci Adv 3, 7, e1700006. https://doi.org/10.1126/sciadv.1700006.

320. Jaffe AE, Tao R, Norris AL, Kealhofer M, Nellore A, Shin JH, Kim D, Jia Y, Hyde TM, Kleinman JE, Straub RE, Leek JT, Weinberger DR (2017), qSVA framework for RNA quality correction in differential expression analysis. Proc Natl Acad Sci USA 114, 27, 7130-7135. https://doi.org/ 10.1073/pnas.1617384114.

321. Buehring GC, Shen HM, Jensen HM, Jin DL, Hudes M, Block G (2015), Exposure to bovine leukemia virus is associated with breast cancer: a case-control study. PLoS One 10, 9, e0134304. https://doi.org/10.1371/journal. pone. 0134304 .

322. Sattler C, Moritz F, Chen S, Steer B, Kutschke D, Irmler M, Beckers J, Eickelberg O, Schmitt-Kopplin P, Adler H, Stoeger T (2017), Nanoparticle exposure reactivates latent herpesvirus and restores a signature of acute infection. Part Fibre Toxicol 141, 2. https://doi.org/10.1186/s12989-0160181-1.

323. Farkašová H, Hron T, Pačes J, Hulva P, Benda P, Gifford RJ, Elleder D (2017), Discovery of an endogenous Deltaretrovirus in the genome of long-fingered bats (Chiroptera: Miniopteridae). Proc Natl Acad Sci USA 114, 12, 3145-3150. https://doi.org/10.1073/pnas.1621224114.

324. Jiang JX, Liu Q, Zhao B, Zhang HH, Sang HM, Djaleel SM, Zhang GX, Xu SF (2017), Risk factors for intestinal metaplasia in a southeastern Chinese population: an analysis of 28,745 cases. J Cancer Res Clin Oncol 143, 3, 409418. https://doi.org/10.1007/s00432-016-2299-9.

325. Hwang YJ, Kim N, Lee HS, Lee JB, Choi YJ, Yoon H, Shin CM, Park YS, Lee DH (2018), Reversibility of atrophic gastritis and intestinal metaplasia after Helicobacter pylori eradication - a prospective study for up to 10 years. Aliment Pharmacol Ther 47, 3, 380-390. https://doi.org/10.1111/ apt.14424.

326. Carrel A, du Noüy PL (1921), Cicatrization of wounds: XI. Latent period. J Exp Med 34, 4, 339-348. https://doi.org/ 10.1084/jem.34.4.339.

327. Carrel A (1921), Cicatrization of wounds: XII. Factors initiating regeneration. J Exp Med 34, 5, 425-434. https://doi.org/10.1084/jem.34.5.425.

328. Carrel A, Ebeling AH (1921), Age and multiplication of fibroblasts. J Exp Med 34, 6, 599-623. https://doi.org/ 10.1084/jem.34.6.599.

329. Fiolet T, Srour B, Sellem L, Kesse-Guyot E, Allès B, Méjean C, Deschasaux M, Fassier P, Latino-Martel P, Beslay M, Hercberg S, Lavalette C, Monteiro CA, Julia C, Touvier M (2018), Consumption of ultra-processed foods and cancer risk: results from NutriNet-Santé prospective cohort. BMJ 360, k322. https://doi.org/10.1136/bmj.k322.

330. Chien CC, Chen HH, Lai SF, Hwu Y, Petibois C, Yang CS, Chu Y, Margaritondo G (2012), X-ray imaging of tumor growth in live mice by detecting gold-nanoparticleloaded cells. Sci Rep 2, 610. https://doi.org/10.1038/ srep00610.

331. Alberts B, Johnson A, Lewis J, Raff M, Roberts K, Walter P (2002), Molecular biology of the cell, 1st edn., Garland Science, New York. ISBN 10: 0-8153-3218-1.

332. Barakat RR, Markam M, Randall ME (2009), Principles and practice of gynecologic oncology, 5th edn., Lippincott Williams \& Wilkins. ISBN 9780781778459.

333. Hoffmann JG, Goltz HL, Reinhard MA, Warner SG (1943), Quantitative determination of the growth of a transplantable mouse adenocarcinoma. Cancer Res 3, 4, 237-242.

334. Brücher BLDM (2018), Science belongs to no one - and to everyone. 4open 1, E1, 1-11. https://doi.org/ 10.1051 /fopen/2017501. 
Cite this article as: Brücher BLDM \& Jamall IS 2019. Synopsis: Special Issue on "Disruption of signaling homeostasis induced crosstalk in 8 the carcinogenesis paradigm Epistemology of the origin of cancer". 4open, 2, 28. 